\title{
FMTVDM Quantitative Nuclear Imaging finds Three Treatments for SARS-CoV-2
}

\author{
Richard M Fleming* and Matthew R Fleming \\ FHHI-OI-Camelot Foundation, Los Angeles, CA, USA \\ *Corresponding author: Richard M Fleming, FHHI-OI-Camelot Foundation, Los Angeles, CA, USA
}

\section{ARTICLE INFO}

Received: 秏 January 19, 2021

Published: 㸷 February 08, 2021

Citation: Richard M Fleming, Matthew R Fleming. FMTVDM Quantitative Nuclear Imaging finds Three Treatments for SARSCoV-2. Biomed J Sci \& Tech Res 33(4) 2021. BJSTR. MS.ID.005443.

Keywords: SARS-CoV-2; CoVid-19; FMTVDM; Ferritin, IL-6; Quantification; Outpatient; Inpatient; Hydroxychloroquine; Azithromycin; Doxcycline; Clindamycin; Primaquine; Remdesivir; Tocilizumab; Methylprednisolone; Interferon $\alpha-2 \beta$; Convalescent Plasma; InflammoThrombotic Response (ITR); Single Sequential Drug Treatment; Dual Drug Treatment; Triple Drug Treatment; Ventilators; Atrovent; Discharge Day; Comorbidities.

Abbreviations: ITR: InflammoThrombotic Response; PCR: Polymerase Chain Reaction; IFC: Informed Consent; FMTDVM: Fleming Method for Tissue and Vascular Differentiation and Metabolism; ROI: Regions-Of-Interest; CVD: Corona Virus Disease; IDW: Ideal Body Weight; ECMO: Extracorporeal Membrane Oxygenation; CI: , Confidence Intervals

\section{ABSTRACT}

Introduction: The SARS-CoV-2 pandemic of 2019 represents the third significant infection from a corona virus during the last two decades; this time producing a pandemic with more than a million deaths due to the immune InflammoThrombotic Response (ITR) to the virus. This investigation studied 10 different treatments and 52 treatment combinations to determine if there is an effective treatment regimen for SARS-CoV-2.

Methods: 1800 people testing positive for SARS-CoV-2 from 23 sites in 7 countries were studied including outpatient and inpatient care and treatment. Outpatients were either treated with an aminoquinoline or followed without specific treatment. Hospitalized patients were divided into two Phases of the study comparing 10 treatments and 52 treatment combinations using quantitative nuclear imaging (FMTVDM), Ferritin and IL- 6 to measure the severity of the infection and resulting ITR in addition to measured treatment response. Phase I looked at treatment outcomes as drug treatments were added sequentially. Phase II looked at combination treatments focusing on treating the immune ITR to SARS-CoV-2. ANOVA was used to determine the effect of each Treatment and Treatment combinations on Treatment outcomes including intubation, extubation, deaths and time to discharge.

Results: Of the 1800 patients seeking medical care, 847 received no outpatient treatment with $59.5 \%$ recovering and $40.5 \%$ requiring hospitalization. Of the 953 treated with an aminoquinoline in the outpatient setting, $16.6 \%$ required further treatment and hospitalization. Five hundred and one people required admission representing a $27.8 \%$ failure to respond to outpatient management. Three hundred and forty patients entered Phase I and received sequentially added medical Treatment(s) until the patient demonstrated treatment success or expired. Of the 340 in Phase I who failed outpatient aminoquinoline treatment, $89.7 \%$ responded to initiation of treatment with Tocilizumab, Interferon $\alpha-2 \beta$, or Methylprednisolone. Combining patients who received outpatient aminoquinoline treatment with those who received no outpatient treatment, $74.5 \%$ of the patients admitted to Phase I responded to Interferon $\alpha-2 \beta$. This number increased to $90 \%$ among patients who received outpatient aminoquinoline treatment. During Phase II of the study patients receiving combination treatments consisting of one of three regimens focusing on treating the immune ITR to SARS-CoV-2 responded $99.83 \%$ of the time. These three ITR regimens consisted of

1. Tocilizumab \& Interferon $\alpha-2 \beta$

2. Primaquine, Clindamycin, Tocilizumab \& Interferon $\alpha-2 \beta$, and

3. Methylprednisolone. These three ITR treatments regimens demonstrated a statistically significant $(\mathrm{p}<0.0001)$ treatment effect and were associated with a significant reduction in intubation with earlier hospital discharge $(\mathrm{p}<0.0001)$.

Conclusion: The answer to the question is, Yes. The treatment of SARS-CoV-2, like HIV, requires a multi-drug treatment regimen focusing on the immune ITR to SARSCoV-2. The three successful treatment regimens include

1. Tocilizumab \& Interferon $\alpha-2 \beta$

2. Primaquine, Clindamycin, Tocilizumab \& Interferon $\alpha-2 \beta$, and

3. Methylprednisolone. These three regimens were effective $99.83 \%$ of the time and shortened hospital stays from $40 \pm 3$ days to $1-2$ weeks. 


\section{Introduction}

During the last two decades there have been three major corona viruses that have impacted world health - SARS, MERS and SARSCoV-2, with SARS-CoV-2 colloquially known as Covid-19. The later has resulted in a pandemic with more than 34-million cases and over 1-million deaths world-wide due to the InflammoThrombotic Response (ITR) produced by the body's immune response to the virus particularly problematic in those who are either immune naive or have comorbidities associated with a hyper inflammatory response resulting in an increased inflammation and thrombosis
$[1,2]$ as shown in Figure 1 [2]. The rapid dissemination of SARSCoV-2 and the lack of preparedness exposed a weakness in the medical response to such pandemics worldwide. Absent a specific treatment to this virus clinicians have independently set out to investigate a variety of treatments based upon differences in survival rates and response to intubation. However, these efforts have exposed both a haphazard approach to medicine, prescribing treatments in the absence of scientific evidence, as well as the political issues associated with the investigation of SARS-CoV-2 origin and treatment.

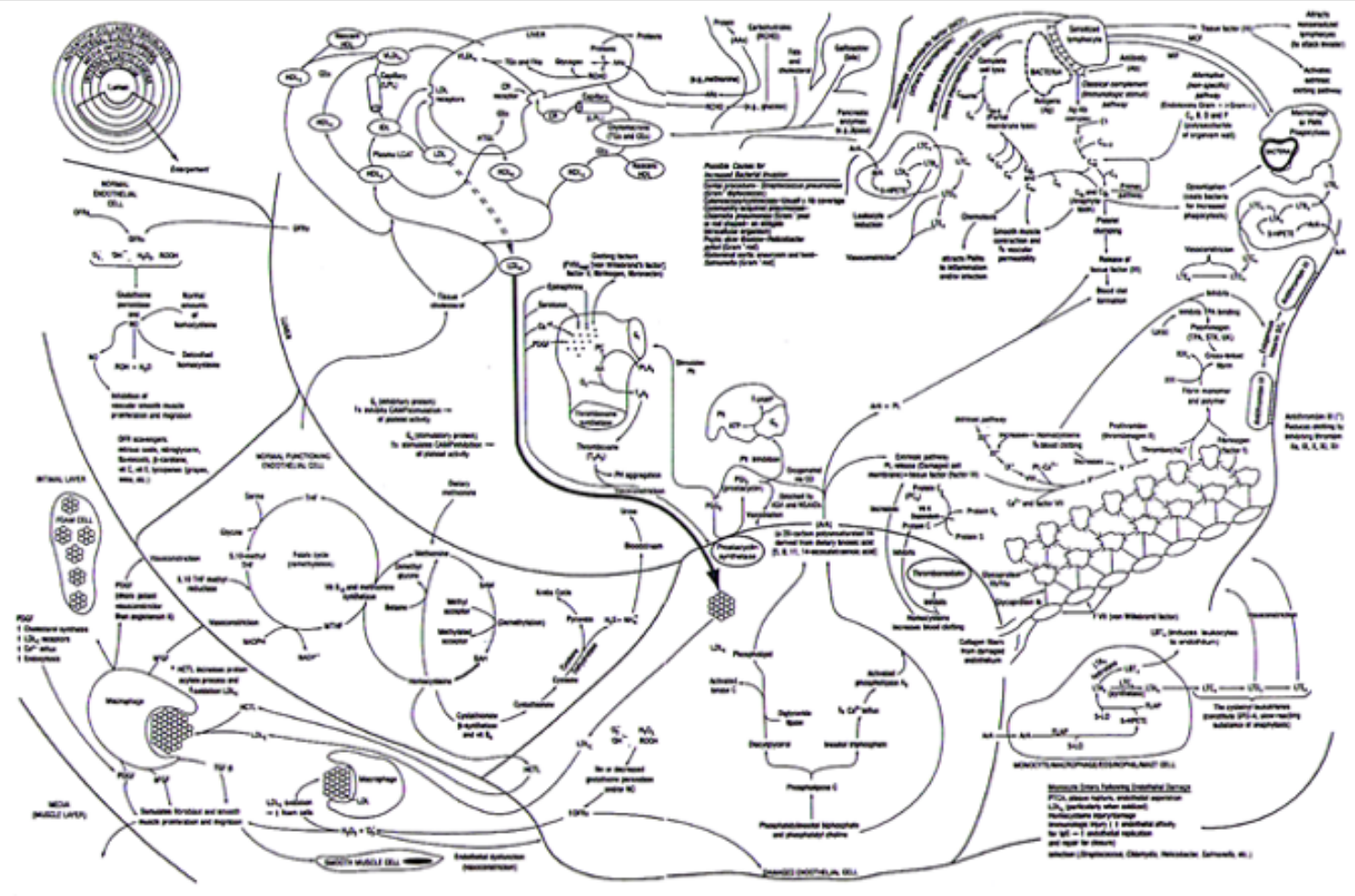

Figure 1: The InflammoThrombotic Response to SARS-CoV-2 [2].

The interactions between the multiple components of the immunologic response to disease - in this instance SARS$\mathrm{CoV}-2$ - and the consequential release of cytokines, interleukins, the complement cascade and clotting factors, result in an InflammoThrombotic Response (ITR) that when not adequately regulated can produce significant inflammation including pulmonary edema and thrombosis.

This investigation looked at 10 different treatments coupled with

a) Efforts to reduce the use of ventilators promoting prone positioning or alternative methods of improved oxygenation to reduce ventilator deaths associated with ARDS [3,4],

b) Immune system augmentation using associated vitamins and minerals demonstrated to be important for best case scenario immune response [2] along with supplementation of magnesium and other medications [5] to reduce problems related to the use of aminoquinolines and other medications that prolong QTc, and c) The use of nebulized medications when possible including the inclusion of Atrovent to reduce bronchial secretions and promote airway dilatation to improve air flow without increasing heart rate or altering QTc. There are FOUR Fundamental Flaws associated with the clinical studies and publications presented to date on the diagnosis, management and treatment of SARS-CoV-2. Consequently, independent of any potential drug treatment(s) studied, the results have been inconsistent and potentially misleading.

First, a failure to measure quantitative changes to determine the severity of the SARS-CoV-2 infection and immunologic ITR to 
the infection, as well as the subsequent measurement of treatment response(s). Second, the failure to sequentially add drug treatments in series - particularly in a short period of time - and measure the individual and drug treatment combinations effect on SARS-CoV-2 infection and ITR. Third, a failure to incorporate this information into a drug treatment regimen combining drug effects from different drugs to determine what combination(s) of drugs can best treat both the infection and the immune ITR to the infection, and
Four, a failure to statistically analyze these outcomes in a manner that allows measurement of the effect of each drug and drug combinations.

The study medications were chosen based upon their proposed and proven mechanisms of action [5-24] for the treatment of SARSCoV-2 patients as shown in Table 5 and not the class of medications these drugs are typically associated to. The treatments medications include:

Table 1: Patient recruitment sites for outpatient and inpatient treatment of SARS-CoV-2.

\begin{tabular}{|c|c|c|c|c|c|c|c|c|}
\hline Study Site & $\begin{array}{l}\text { Continent of } \\
\text { Country }\end{array}$ & Start & Stop & $\begin{array}{l}\text { Total Number of } \\
\text { Patients }\end{array}$ & $\begin{array}{l}\text { Outpatient } \\
\text { HCQ Success }\end{array}$ & $\begin{array}{c}\text { Outpatient Success } \\
\text { without } \mathbf{R x}\end{array}$ & $\begin{array}{l}\text { Phase I } \\
\text { Patients }\end{array}$ & $\begin{array}{l}\text { Phase II } \\
\text { Patients }\end{array}$ \\
\hline 1 & Cuba & $4 / 16 / 20$ & $4 / 30 / 20$ & 56 & 32 & 17 & 7 & 0 \\
\hline 2 & India & $4 / 16 / 20$ & $5 / 11 / 20$ & 49 & 23 & 17 & 9 & 0 \\
\hline 3 & India & $4 / 16 / 20$ & $5 / 20 / 20$ & 114 & 39 & 30 & 18 & 27 \\
\hline 4 & Cuba & $4 / 24 / 20$ & $4 / 30 / 20$ & 32 & 24 & 5 & 3 & 0 \\
\hline 5 & Philippines & $4 / 27 / 20$ & $6 / 15 / 20$ & 34 & 27 & 1 & 6 & 0 \\
\hline 6 & Philippines & $4 / 29 / 20$ & $6 / 8 / 20$ & 47 & 22 & 11 & 14 & 0 \\
\hline 7 & India & $4 / 30 / 20$ & $5 / 22 / 20$ & 58 & 30 & 19 & 9 & 0 \\
\hline 8 & S. Africa & $5 / 7 / 20$ & $5 / 7 / 20$ & 5 & 3 & 0 & 2 & 0 \\
\hline 9 & Belgium & $5 / 11 / 20$ & $5 / 20 / 20$ & 25 & 9 & 5 & 11 & 0 \\
\hline 10 & Germany & $5 / 11 / 20$ & $6 / 19 / 20$ & 145 & 82 & 41 & 22 & 0 \\
\hline 11 & Germany & $5 / 14 / 20$ & $6 / 1 / 20$ & 57 & 22 & 11 & 24 & 0 \\
\hline 12 & Brazil & $5 / 18 / 20$ & $6 / 22 / 20$ & 142 & 65 & 49 & 28 & 0 \\
\hline 13 & Belgium & $5 / 18 / 20$ & $6 / 18 / 20$ & 135 & 58 & 38 & 39 & 0 \\
\hline 14 & Belgium & $5 / 18 / 20$ & $6 / 19 / 20$ & 152 & 60 & 43 & 49 & 0 \\
\hline 15 & India & $5 / 18 / 20$ & $6 / 19 / 20$ & 95 & 18 & 18 & 59 & 0 \\
\hline 16 & Germany & $5 / 19 / 20$ & $5 / 27 / 20$ & 79 & 49 & 20 & 10 & 0 \\
\hline 17 & Germany & $5 / 22 / 20$ & $5 / 29 / 20$ & 16 & 7 & 0 & 9 & 0 \\
\hline 18 & India & $5 / 22 / 20$ & $6 / 19 / 20$ & 168 & 90 & 27 & 21 & 30 \\
\hline 19 & Brazil & $7 / 9 / 20$ & $8 / 4 / 20$ & 94 & 51 & 27 & 0 & 16 \\
\hline 20 & Brazil & $7 / 9 / 20$ & $8 / 3 / 20$ & 98 & 48 & 25 & 0 & 25 \\
\hline 21 & Philippines & $7 / 9 / 20$ & $8 / 5 / 20$ & 93 & 36 & 36 & 0 & 21 \\
\hline 22 & Cuba & $7 / 10 / 20$ & $7 / 31 / 20$ & 40 & 0 & 29 & 0 & 11 \\
\hline 23 & Brazil & $7 / 13 / 20$ & $8 / 4 / 20$ & 66 & 0 & 35 & 0 & 31 \\
\hline Totals: & $4 / 16 / 20$ & $8 / 5 / 20$ & 1800 & 795 & 504 & 340 & 161 & \\
\hline
\end{tabular}

1. Inhibition of viral attachment and replication,

2. Reduction of harmful ITR during the initial innate rapidonset T-cell cytotoxic immune response,

3. Enhancement of patient oxygenation, and

4. Reduction of harmful ITR response associated with adaptive humoral (antibody) response.

To determine if these treatments could successfully treat the attachment and replication of SARS-CoV-2 and/or the ITR associated with the immunologic response to the virus, we investigated 10 different treatment arms [6-25] eventually applying 52 different treatment combinations. The outcomes of these treatments were objectively measured including changes in tissue response using FMTVDM [26,27], as well as blood markers of ITR; viz. Ferritin [28] and IL-6 [29] levels. They were also subjectively evaluated using frequency of intubation, associated deaths, time to extubation and discharge. Given the tremendous political, pharmaceutical and social influences involved in the investigation of SARS-CoV-2, this study was conducted outside of the United States at sites where there were both significant numbers of SARS-CoV-2 cases reported and where clinicians were treating patients without government intervention. Accordingly study participants have deleted all identifiers to ensure full participation. 


\section{Methods}

\section{Enrollment}

Twenty-three independent sites from seven countries participated in a blinded randomized prospective comparison of 10 treatment arms for patients who tested positive for SARSCoV-2 (Covid-19) by Polymerase Chain Reaction (PCR). Patient recruitment for NCT04349410 ran from 16 April 2020 through 4 August 2020. The study and the patient Informed Consent (IFC) was approved by the central Institutional Review Board (OMB No. 09900270; IORG0010573) and independently approved at each site. Any and all information identifying patients, sites or investigators were redacted prior to release to the IRB. Participation in the clinical trial followed agreement to protect intellectual property and forfeiture of any rights to the released redacted data to the IRB.

\section{Inclusion Criteria}

Patients were included in the study only if they were under the care of a medical doctor, signed IFC and tested positive by Polymerase Chain Reaction (PCR) for SARS-CoV-2.

\section{Exclusion Criteria}

Patients were excluded from participation in the study if they were PCR negative, actively undergoing treatment for cancer, were surgical patients, pregnant or were under 16-years of age. Patients were also excluded from the study if they had already been admitted to hospital for treatment prior to recruitment or if they had a known medical problem that would prohibit them from being treated by any of the treatments being used in this study - e.g. patients with a glucose-phosphate dehydrogenase deficiency (G-6PD), sickle cell deficiency or disease, et cetera.

\section{Outpatient Treatment}

Patient recruitment for each outpatient treatment site is shown in Tables $1 \& 2$ and Figure 2. Outpatient treatment was by definition provided by clinicians prior to hospital admission. Outpatient sites included private offices, physician and hospital clinics. Decision to treat (Treatments 1-4; Tables 3A \& 3B) was made solely by the physician and patient. All outpatients received a minimum of 200 mg of elemental zinc daily while taking aminoquinolines. Following initial evaluation including PCR testing and initiation of treatment or the decision to provide no treatment, patients returned 3-5 days later for re-evaluation. Patients deemed to have responded well either to treatment or no treatment were recorded as such. Those who were determined to have deteriorated clinically were admitted to hospital. Outpatients did not undergo FMTVDM, Ferritin or IL-6 testing.

Table 2: Patient characteristics for each component of the study.

\begin{tabular}{|c|c|c|c|c|c|c|c|c|c|c|c|}
\hline Study & $\begin{array}{l}\text { Number of } \\
\text { Patients }\end{array}$ & $\begin{array}{l}\text { Age** }^{* *} \\
\text { (Years) }\end{array}$ & Male (\%) & $\begin{array}{c}\text { Female } \\
(\%)\end{array}$ & $\begin{array}{l}\text { CAD } \\
\text { (\%) }\end{array}$ & D.M. (\%) & $\begin{array}{l}\text { HTN } \\
(\%)\end{array}$ & $\begin{array}{l}\text { Prior } \\
\text { CA (\%) }\end{array}$ & $\begin{array}{c}\text { Entry } \\
\text { FMTVDM }^{* *}\end{array}$ & $\begin{array}{c}\text { Entry } \\
\text { Ferritin** }\end{array}$ & $\begin{array}{l}\text { Entry } \\
\text { IL-6** }\end{array}$ \\
\hline $\begin{array}{c}\text { Recovered as } \\
\text { Outpatient without } \\
\text { Treatment }\end{array}$ & 504 & $\begin{array}{c}51 \pm \\
22\end{array}$ & $\begin{array}{c}338(67.1 \\
\%)\end{array}$ & $\begin{array}{c}166 \\
(32.9 \\
\%)\end{array}$ & $\begin{array}{c}125 \\
(24.8 \\
\%)\end{array}$ & $\begin{array}{c}143 \\
(28.4 \%)\end{array}$ & $\begin{array}{c}117 \\
(23.2 \\
\%)\end{array}$ & $\begin{array}{c}146 \\
(29 \%)\end{array}$ & $\mathrm{ND}^{*}$ & ND & ND \\
\hline $\begin{array}{l}\text { Responded to HCQ } \\
\text { as Outpatient }\end{array}$ & 795 & $\begin{array}{c}62 \pm \\
17\end{array}$ & $\begin{array}{c}578 \\
(72.7 \%)\end{array}$ & $\begin{array}{c}217 \\
(27.3 \%)\end{array}$ & $\begin{array}{c}256 \\
(32.2 \\
\%)\end{array}$ & $\begin{array}{c}124 \\
(15.6 \%)\end{array}$ & $\begin{array}{c}219 \\
(27.5 \\
\%)\end{array}$ & $\begin{array}{c}181 \\
(22.8 \\
\%)\end{array}$ & ND & ND & ND \\
\hline $\begin{array}{l}\text { Failed HCQ as } \\
\text { Outpatient and En- } \\
\text { rolled in Phase I }\end{array}$ & 39 & $\begin{array}{c}62 \pm \\
17\end{array}$ & $\begin{array}{c}32 \\
(82 \%)\end{array}$ & $\begin{array}{c}7 \\
(17.9 \%)\end{array}$ & $\begin{array}{c}10 \\
(25.6 \\
\%)\end{array}$ & $\begin{array}{c}13 \\
(33.3 \%)\end{array}$ & $\begin{array}{c}9 \\
(23.1 \\
\%)\end{array}$ & $\begin{array}{c}6 \\
(15.4 \%)\end{array}$ & $202 \pm 27$ & $521 \pm 240$ & $\begin{array}{c}51 \pm \\
12\end{array}$ \\
\hline $\begin{array}{l}\text { Enrolled in Phase } \\
\text { I with no prior } \\
\text { treatment. }\end{array}$ & 301 & $\begin{array}{c}68 \pm \\
17\end{array}$ & $\begin{array}{c}179 \\
(59.5 \%)\end{array}$ & $\begin{array}{c}122 \\
(40.5 \%)\end{array}$ & $\begin{array}{c}75 \\
(24.9 \\
\%)\end{array}$ & $\begin{array}{c}57 \\
(18.9 \%)\end{array}$ & $\begin{array}{c}104 \\
(34.6 \\
\%)\end{array}$ & $\begin{array}{c}64 \\
(21.3 \%)\end{array}$ & $199 \pm 22$ & $700 \pm 157$ & $\begin{array}{c}55 \\
\pm 16\end{array}$ \\
\hline $\begin{array}{l}\text { Failed HCQ as } \\
\text { Outpatient and En- } \\
\text { rolled in Phase II }\end{array}$ & 119 & $\begin{array}{c}59 \pm \\
20\end{array}$ & $\begin{array}{c}97 \\
(81.5 \%)\end{array}$ & $\begin{array}{c}22 \\
(18.5 \%)\end{array}$ & $\begin{array}{c}24 \\
(20.2 \\
\%)\end{array}$ & $\begin{array}{c}34 \\
(28.6 \%)\end{array}$ & $\begin{array}{c}32 \\
(26.9 \\
\%)\end{array}$ & $\begin{array}{c}26 \\
(21.8 \%)\end{array}$ & $192 \pm 24$ & $539 \pm 237$ & $\begin{array}{c}52 \pm \\
14\end{array}$ \\
\hline $\begin{array}{l}\text { Enrolled in Phase } \\
\text { II with no prior } \\
\text { treatment. }\end{array}$ & 42 & $\begin{array}{c}55 \pm \\
20\end{array}$ & $\begin{array}{c}38 \\
(90.5 \%)\end{array}$ & $\begin{array}{c}4 \\
(9.5 \%)\end{array}$ & $\begin{array}{c}6 \\
(14.3 \\
\%) \\
\end{array}$ & $\begin{array}{c}9 \\
(21.4 \%)\end{array}$ & $\begin{array}{c}7 \\
(16.7 \\
\%)\end{array}$ & $\begin{array}{c}0 \\
(0 \%)\end{array}$ & $210 \pm 24$ & $810 \pm 117$ & $72 \pm 10$ \\
\hline Total & 1800 & $\begin{array}{c}59 \pm \\
19\end{array}$ & $\begin{array}{c}1262 \\
(70.1 \%)\end{array}$ & $\begin{array}{c}538 \\
(29.9 \%)\end{array}$ & $\begin{array}{c}496 \\
(27.6 \\
\%)\end{array}$ & $\begin{array}{c}380 \\
(21.1 \%)\end{array}$ & $\begin{array}{c}488 \\
(27.1 \\
\%)\end{array}$ & $\begin{array}{c}423 \\
(23.5 \%)\end{array}$ & & & \\
\hline
\end{tabular}

Note: *ND = No data

**Values provided as mean standard \pm deviation. 
Table 3A: SARS-CoV-2 Treatment components for Extubated Patients.

\begin{tabular}{|c|c|c|c|c|c|c|c|c|c|c|c|}
\hline & 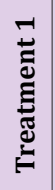 & 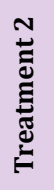 & 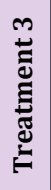 & 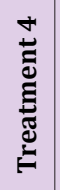 & 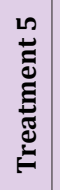 & 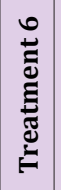 & 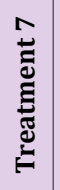 & 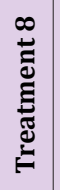 & 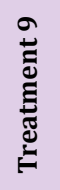 & 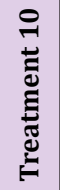 & 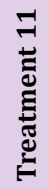 \\
\hline \multicolumn{12}{|l|}{ Immune Support } \\
\hline $\begin{array}{l}\text { Folate } 3 \mathrm{mg} \text { by mouth daily, Magnesium } 400 \mathrm{mg} \text { by mouth daily, Calcium Carbonate } 400 \\
\text { mg by mouth daily, Cobalamin } 3 \mathrm{mg} \text { by mouth daily, Pyridoxine } 30 \mathrm{mg} \text { by mouth daily, De- } \\
\text { hydroepiandrosterone } 50 \mathrm{mg} \text { by mouth twice daily, Ascorbic acid } 2000 \mathrm{mg} \text { by mouth daily, } \\
\text { Zinc } 10 \mathrm{mg} \text { by mouth daily, and 1,25-dihydroxycholecalciferol } 1500 \mathrm{IU} \text { by mouth daily. }\end{array}$ & $\mathrm{x}$ & $\mathrm{X}$ & $\mathrm{X}$ & $\mathrm{X}$ & $\mathrm{X}$ & $\mathrm{X}$ & $\mathrm{X}$ & $\mathrm{X}$ & $\mathrm{X}$ & $\mathrm{X}$ & $\mathrm{X}$ \\
\hline \multicolumn{12}{|l|}{ Respiratory Support } \\
\hline Atrovent nebulizer treatment every 4-hours. & $\mathrm{x}$ & $\mathrm{X}$ & $\mathrm{X}$ & $\mathrm{X}$ & $\mathrm{X}$ & $\mathrm{X}$ & $\mathrm{X}$ & $\mathrm{X}$ & $\mathrm{X}$ & $\mathrm{x}$ & $\mathrm{X}$ \\
\hline \multicolumn{12}{|l|}{ SARS-CoV-2 Targeted Treatments } \\
\hline Hydroxychloroquine $200 \mathrm{mg}$ by mouth every 8 -hours ( $600 \mathrm{mg}$ daily) for 10 -days. & $\mathrm{X}$ & $\mathrm{X}$ & $\mathrm{X}$ & $\mathrm{X}$ & & & & & & & \\
\hline Azithromycin $500 \mathrm{mg}$ by mouth Day 1 , then $250 \mathrm{mg}$ by mouth Days $2-5$. & $\mathrm{x}$ & & & & & & & & & & \\
\hline Doxycycline $100 \mathrm{mg}$ by mouth every 12 -hours for 10 -days. & & $\mathrm{X}$ & & & & & & & & & \\
\hline Clindamycin $150 \mathrm{mg}$ by mouth every 6-hours for 7 -days. & & & $\mathrm{X}$ & $\mathrm{X}$ & $\mathrm{x}$ & & & & & & \\
\hline Primaquine $200 \mathrm{mg}$ by mouth Day \#1 & & & & $\mathrm{X}$ & $\mathrm{X}$ & & & & & & \\
\hline \multicolumn{12}{|c|}{$\begin{array}{c}\text { Originally Part of Treatment 5: Hydroxychloroquine Day } 1800 \mathrm{mg} \text { by Mouth, then } 400 \mathrm{mg} \text { 8-hours later. Days } 2 \text { and } 3400 \mathrm{mg} \text { by Mouth daily } \\
\text {-- Deleted }\end{array}$} \\
\hline Remdesivir $200 \mathrm{mg}$ IV on day 1 , then $100 \mathrm{mg}$ IV days $2-10$. & & & & & & $\mathrm{x}$ & & & & & \\
\hline $\begin{array}{l}\text { Tocilizumab 8-mg/kg [IBW; not to exceed } 800 \mathrm{mg}] \text { not to exceed } 800 \mathrm{mg} \text { intravenously } \\
\text { infused over 1-hour. May be repeated every 8-hours for a maximum of 4-doses. }\end{array}$ & & & & & & & $\mathrm{X}$ & & & & \\
\hline $\begin{array}{l}\text { Methylprednisolone } 125 \mathrm{mg} \text { IV every 6-hours for } 3 \text { days; then } 125 \mathrm{mg} \text { IV every } 12 \text {-hours for } \\
2 \text { days; then } 125 \mathrm{mg} \text { IV daily for } 2 \text { days; then } 60 \mathrm{mg} \text { IV daily for } 2 \text { days [with each infusion } \\
\text { given over } 30 \text {-minutes]; then Solumedrol dose pack to taper off steroids. }\end{array}$ & & & & & & & & $\mathrm{X}$ & & & \\
\hline Interferon a-2b 5-million units per nebulizer every 12 -hours for 7 -days. & & & & & & & & & $\mathrm{X}$ & & \\
\hline \multicolumn{12}{|c|}{ Treatment 10: Losartan 25 Mg by Mouth Daily -- Deleted } \\
\hline $\begin{array}{l}\text { Convalescent Plasma 2-units ABO-compatible with antibody titer of 1:320 dilution. Each } \\
\text { unit intravenously infused by over 4-hours. }\end{array}$ & & & & & & & & & & & $\mathrm{X}$ \\
\hline
\end{tabular}

Table 3B: SARS-CoV-2 Treatment components for Intubated Patients.

\begin{tabular}{|c|c|c|c|c|c|c|c|c|c|c|c|}
\hline & 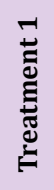 & 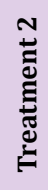 & 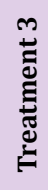 & 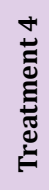 & 告 & 艺 & 蓠 & 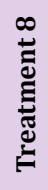 & 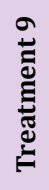 & 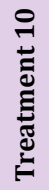 & 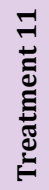 \\
\hline \multicolumn{12}{|l|}{ Immune Support } \\
\hline $\begin{array}{l}\text { Folate } 3 \mathrm{mg} \text { intravenous daily, Magnesium } 400 \mathrm{mg} \text { intravenous (IV) daily, Calcium Carbon- } \\
\text { ate } 4 \mathrm{mEq} / \mathrm{Kg} \text { IV daily not to exceed } 400 \mathrm{mg} \text { daily, Cobalamin } 3 \mathrm{mg} \text { IV daily, Pyridoxine } \\
30 \mathrm{mg} \text { IV daily, Dehydroepiandrosterone } 50 \mathrm{mg} \text { IV daily, Ascorbic acid } 2000 \mathrm{mg} \text { IV daily, } \\
\text { Zinc } 4 \mathrm{mg} \text { IV daily, and 1,25-dihydroxycholecalciferol } 1500 \text { IU by oral solution if possible } \\
\text { daily-not available IV. Each vitamin infusion should be given over } 15 \text { to } 30 \text {-minutes. }\end{array}$ & $X$ & $X$ & $X$ & $X$ & $X$ & $X$ & $X$ & $X$ & $X$ & $X$ & $\mathrm{X}$ \\
\hline \multicolumn{12}{|l|}{ Respiratory Support } \\
\hline Atrovent nebulizer treatment every 4-hours. & $\mathrm{X}$ & $\mathrm{X}$ & $\mathrm{x}$ & $\mathrm{x}$ & $\mathrm{X}$ & $\mathrm{X}$ & $\mathrm{X}$ & $\mathrm{X}$ & $\mathrm{X}$ & $\mathrm{x}$ & $\mathrm{X}$ \\
\hline \multicolumn{12}{|l|}{ SARS-CoV-2 Targeted Treatments } \\
\hline Hydroxychloroquine $155 \mathrm{mg}$ IV every 8-hours (600 mg daily) for 10-days. & $\mathrm{X}$ & $\mathrm{X}$ & $\mathrm{x}$ & $\mathrm{x}$ & & & & & & & \\
\hline Azithromycin $500 \mathrm{mg}$ by vein over 1-hour Day 1 , then $250 \mathrm{mg}$ Days 2-5. & $\mathrm{X}$ & & & & & & & & & & \\
\hline Doxycycline 100 mg by vein over 1-hour every 12 -hours for 10 -days. & & $\mathrm{X}$ & & & & & & & & & \\
\hline Clindamycin $150 \mathrm{mg}$ by vein over 1 -hour every 6-hours for 7-days. & & & $\mathrm{X}$ & $\mathrm{x}$ & $\mathrm{X}$ & & & & & & \\
\hline Primaquine $200 \mathrm{mg}$ by mouth Day \#1 - Unavailable for Intubated Patient & & & & $X$ & $X$ & & & & & & \\
\hline
\end{tabular}


Originally Part of Treatment 5: Hydroxychloroquine Day $1800 \mathrm{mg}$ by Mouth, then $400 \mathrm{mg}$ 8-hours later. Days 2 and $3400 \mathrm{mg}$ by Mouth daily -- DELETED

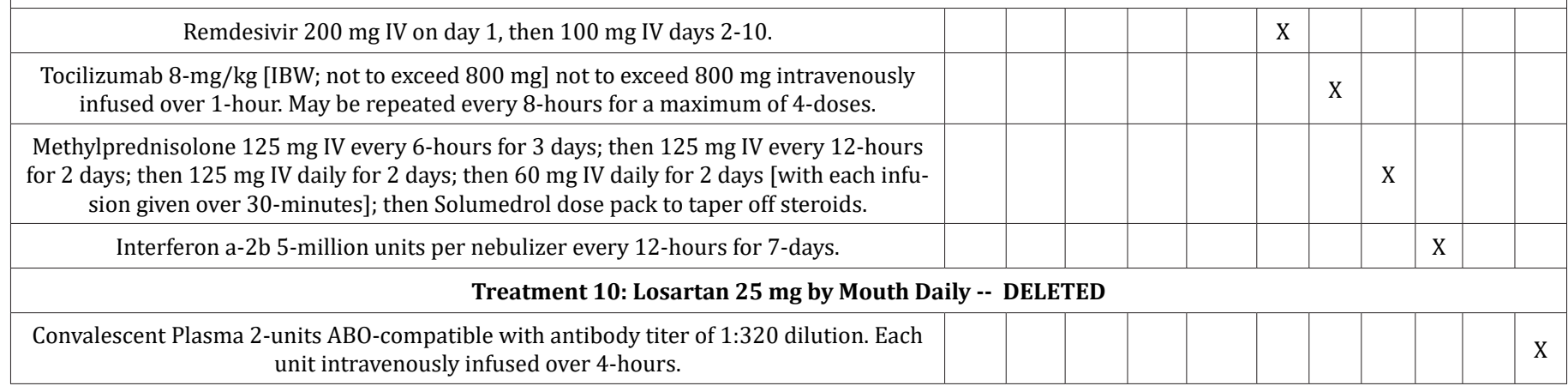

\section{Inpatient Treatment}

Patients who were deemed to have failed outpatient treatment and required admission to hospital followed the protocol shown in
Figure 2 and were subsequently enrolled in either Phase I (Figures $2 \& 3$ ) or II (Figure 4) of the study as defined below.

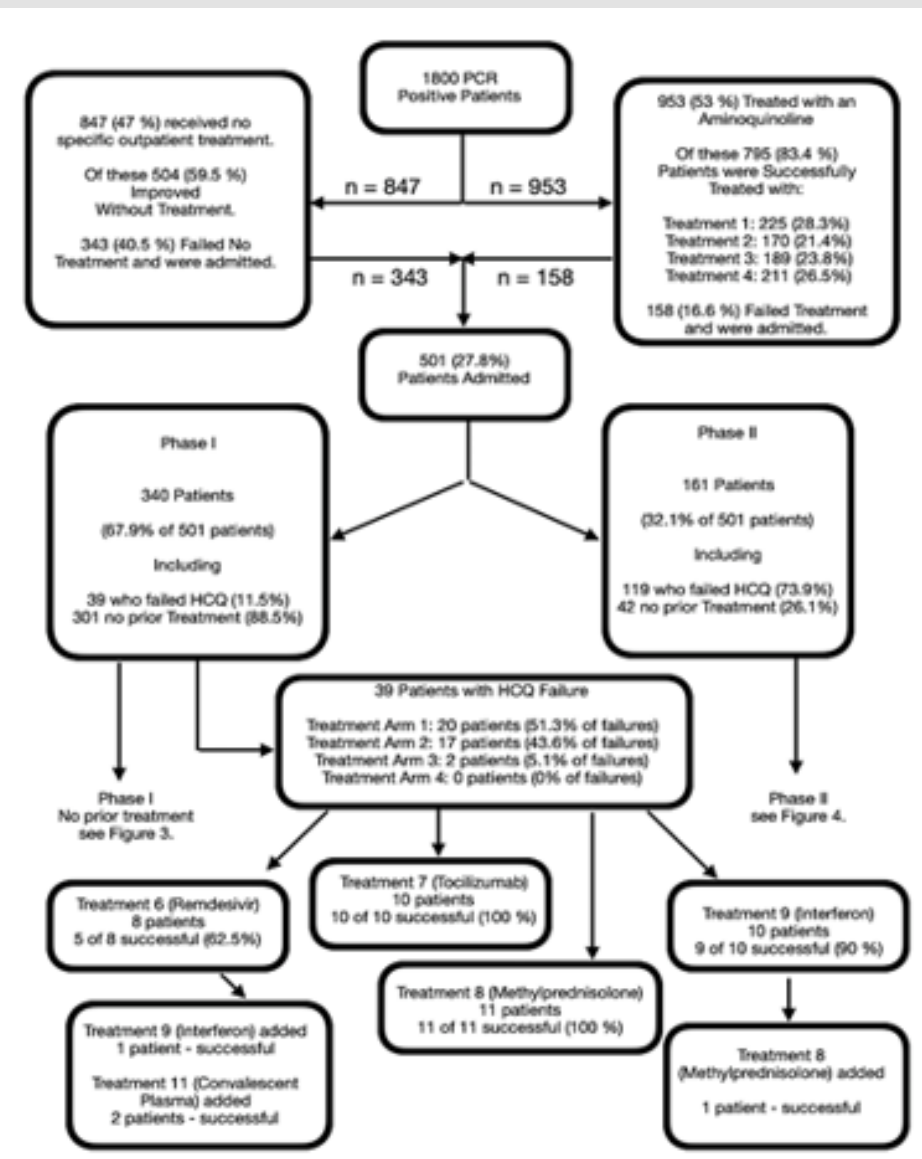

Figure 2: Initial patient inflow into the study.

1800 individuals who were PCR positive for SARS-CoV-2 were enrolled in the study. Among these individuals physicians began treating 953 with one of four hydroxychloroquine (HCQ) treatment regimens as defined in Tables 3A and 3B. Of these $795(83.4 \%)$ responded favorable and did not require hospital admission. The remaining $158(16.6 \%)$ were admitted to hospital. Thirty-nine of these patients were admitted into Phase I of the study along with 301 individuals who had not received treatment as outpatients. The remaining 119 patients who failed HCQ outpatient treatment were admitted to Phase II along with 42 other individuals who had not received prior treatment and required admission. The outcomes of the patient responses to outpatient aminoquinoline treatment are shown in Tables 1,2,6,11. An additional 847 patients did not receive outpatient treatment. Of these 504 (59.5 \%) did well; however, 343 (40.5 \%) required admission. Of these 301 were assigned to Phase I, and 42 were assigned to Phase II of the study. 


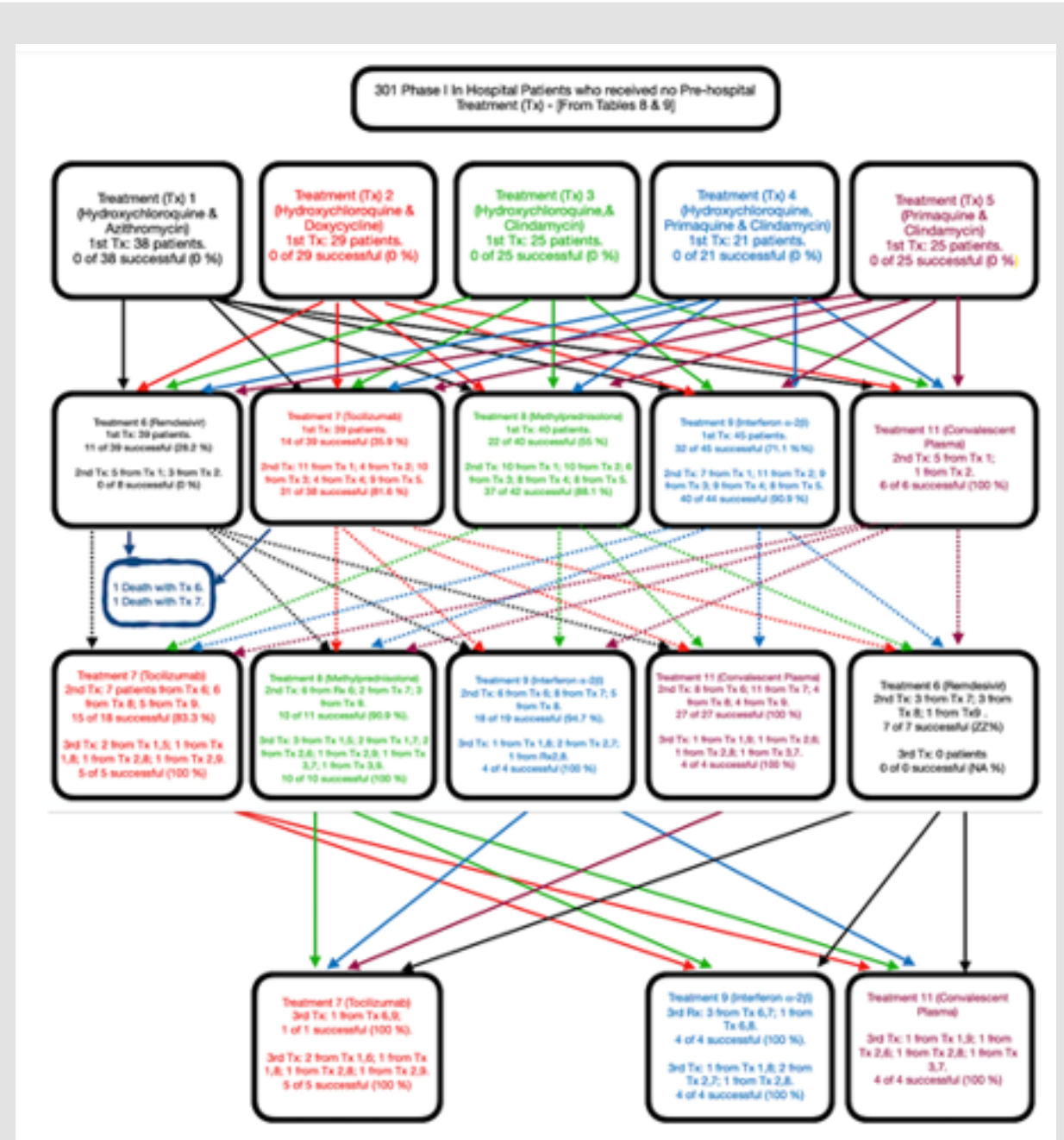

Figure 3: Phase I Flow of Patients who Received no HCQ Treatment Prior to Admission.

Three hundred and one patients who had not received outpatient treatment were enrolled in Phase I. The first two horizontal rows show the ten initial single treatment arms - each of which is represented by a specific color that continues throughout the flow diagram. Only treatment arm 11 (Convalescent Plasma) was not provided as an initial treatment as explained in the text of the manuscript. The solid colored arrows from row one (Treatments 1-5) show the next sequential treatment added if the first treatment failed to successfully treat SARS-CoV-2. Failure to successfully treat SARS-CoV-2 after a treatment found in horizontal line two, resulted in an additional treatment being added in horizontal treatment line 3 . The connections between the treatments in line two and three are shown by the dashed color line associated with the treatment color in horizontal treatment line two and three. Each treatment box shows the number of patients treated with the treatment regimen and the success of treatment. E.g. In row one, the second Treatment group is Treatment (Tx) 2. This is the combination of Hydroxychloroquine and Doxycycline. Twenty-nine patients received this treatment and all failed with $0 \%$ success. This Treatment group is recorded in red print with solid red arrows leading to multiple second line serial drugs - noted by the solid red arrows - being added to the regimen. One of these red arrows leads straight down to Treatment (Tx) 7 (Tocilizumab) in the second row of drug treatments. Tx 7 is also in red print and the lined arrows leading away from it are dashed red lines. While Tx 7 was also used as a first line drug, the second set of numbers show the outcomes when Tocilizumab is added as an additional second drug. On the first line of second line treatments (Tx), the second group noted reads " 4 from Tx 2 " meaning there were 4 patients who had received Treatment 2 (Hydroxychloroquine and Doxcycline) who were then treated with the addition of Treatment 7 (Tocilizumab). Of the 38 total patients receiving Tocilizumab as an additional second line treatment $31(81.6 \%)$ responded favorably to treatment. However, seven did not. Of these seven patients, dashed red arrow lines lead from Tx 7 to a third drug Treatment added to the regimen. One of these red dashed lines flows to the third line of Treatments including Treatment 9 (third from left) in blue print. Treatment (Tx) 9 is Interferon $\alpha-2 \beta$. In this box you will see the results of Interferon $\alpha-2 \beta$ being used as second and third line Tx. [Its use as a first line treatment is noted in the second line of drug treatments; also in blue print.] Under the $3^{\text {rd }} \mathrm{Tx}$ line the second item reads " 2 from Tx 2,7" denoting there were two patients who previously received Treatment 2 then Treatment 7 , who were now receiving a third Treatment 9 (Interferon $\alpha-2 \beta$ ). As noted four of the patients receiving the triple drug treatment with Interferon $\alpha-2 \beta$, including the two receiving Treatments $2,7,9$; responded successfully $(100 \%)$. Tables $7 \& 8$ provides the tabulated information found in Figure 3. 


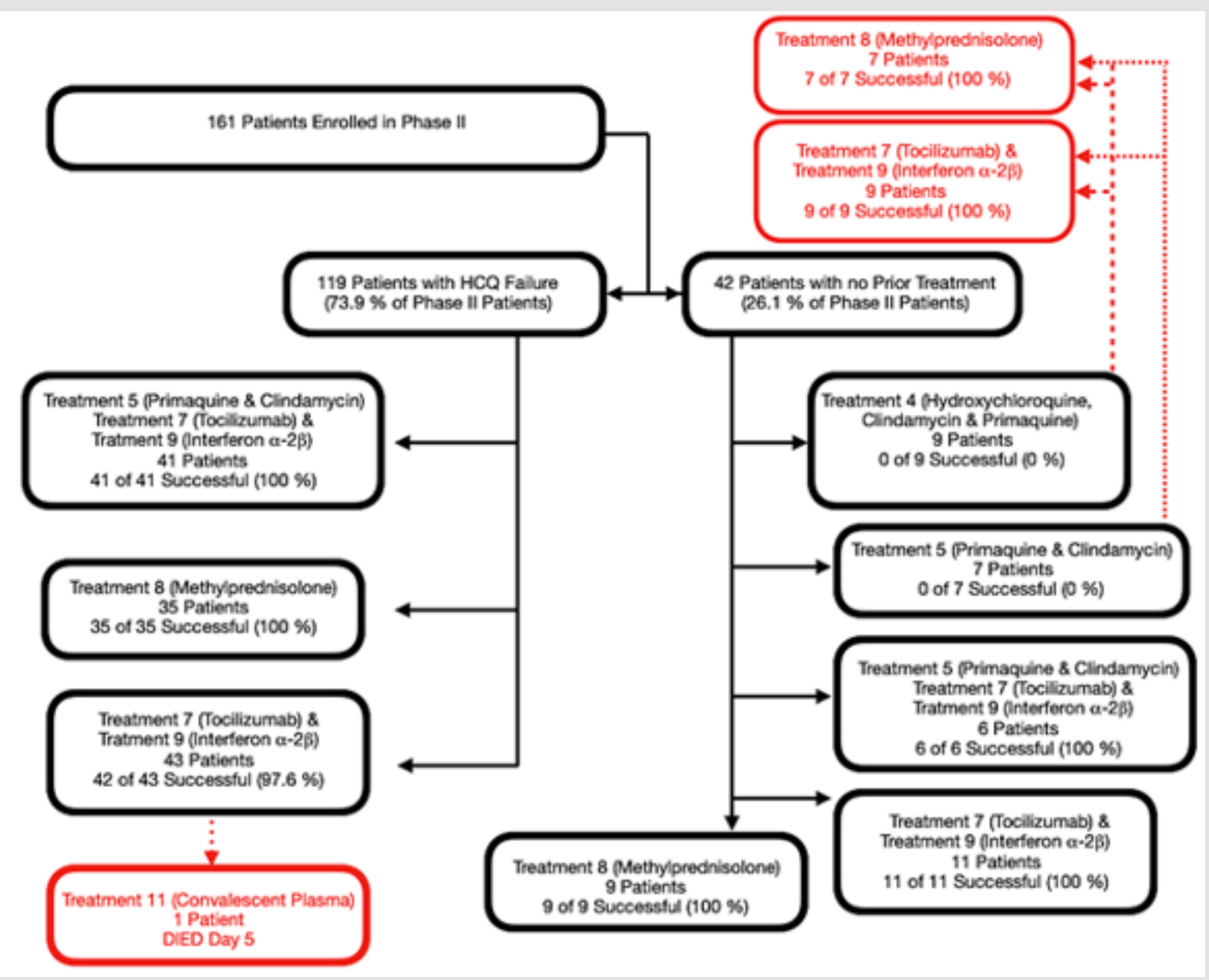

Figure 4: Phase II Patients Clinical Flow.

Phase II of the study-initiated treatment focusing on reducing the ITR of SARS-CoV-2 patients. Treatment options consisted of multi-drug combinations or the administration of methylprednisolone. Of the 161-patients enrolled in Phase II, 119 had failed outpatient HCQ treatment and were randomly assigned to receive either a combination treatment of Treatments 5, 7 and 9, or the combination treatment of Treatment 7 and 9. Alternatively patients were randomly assigned to receive Treatment 8. An additional 42-patients who had not received a HCQ outpatient treatment were randomly assigned to these same three groups or to receive treatment 4 or 5 . During Phase II of the study only those who initially received treatment 4 or 5 required the addition of a sequential treatment and they were randomly assigned to receive either Treatment 8 or the combination Treatment of 7 and 9 . The outcomes of the treatment success for these patients are shown in Table 9.

Quantitative And Serial Determination Of Sars-Cov-2 Severity Prior To Initiating Hospital Treatment Detailed

\section{In Tables 3A \& 3B}

Determination of the severity of SARS-CoV-2 using nuclear imaging has become a major and the newest tool for clinicians [30]. In this study the quantified nuclear imaging method used [26] was the Fleming Method for Tissue and Vascular Differentiation and Metabolism (FMTVDM) permitting measurement of tissue changes in regional blood flow and metabolism resulting from SARS-CoV-2 and the ITR to the virus as shown in Figure 5. Comparison studies using FMTVDM for other disease states [30] has permitted the differentiation of tissue changes showing progression of changes resulting from increasing regional blood flow and metabolism shown in Figure 6 with progressive worsening of infectious and inflammatory diseases. The nuclear technologist was solely responsible for quantitative camera calibration and patient image acquisition and quantification of Regions-Of-Interest (ROIs). The first study was done upon admission to the hospital and prior to initiation of treatment. Serial imaging and tissue measurement was performed at 72-hour increments following initiation of each treatment and was continued in 72-hour increments until satisfactory treatment of SARS-CoV-2 had been achieved as defined by a reduction in FMTVDM of $\geq 25$ or a final FMTVDM value of $\leq 150$. The greatest ROI measured FMTVDM value was used to determine the severity of Corona Virus Disease (CVD). 


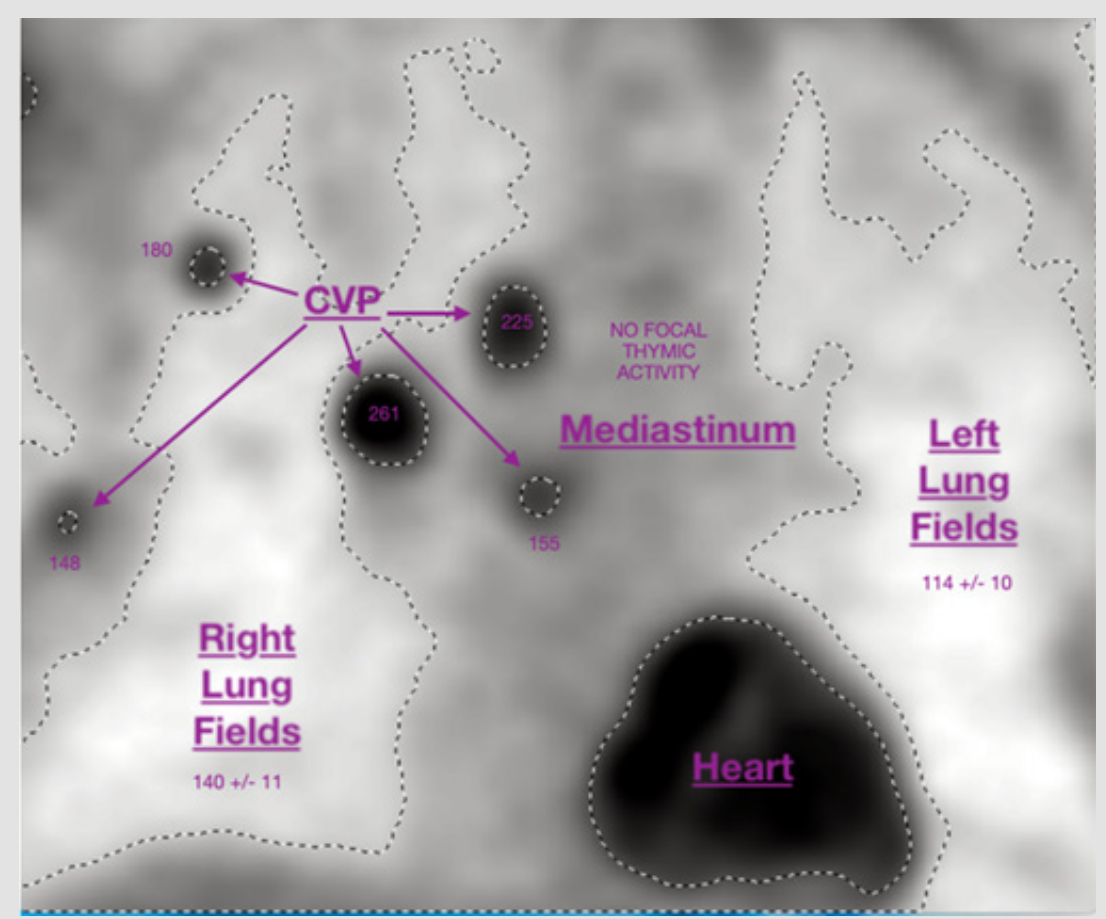

Figure 5: FMTVDM quantitative measurements of SARS-CoV-2 corona virus pneumonia (CVP) severity and ITR.

FMTVDM quantitative measurements of the severity of SARS-CoV-2 corona virus pneumonia (CVP) associated changes in regional blood flow and metabolism were obtained for each inpatient before and after each period of treatment to determine treatment success. Regions-of-interest (ROIs) were obtained and quantified. The greatest FMTVDM value was reported for each patient study. In this example the greatest FMTVDM measured value was 261. Serial studies were obtained and used to determine measured treatment success. Successful treatment was defined as a reduction in FMTVDM of $\geq 25$ or a value of $\leq$ 150. The results are shown in Tables $4 \& 10$.

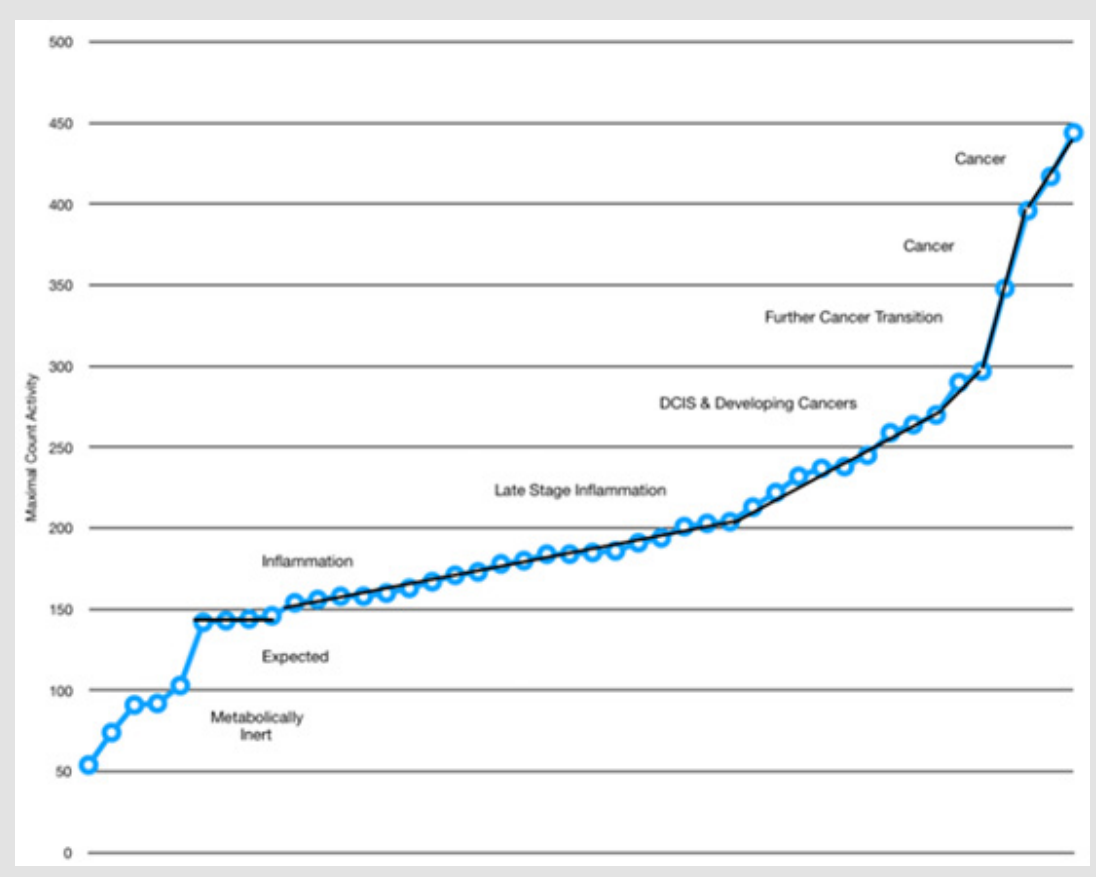

Figure 6: Measurement of changes in regional blood flow and metabolism seen with sequential changes in tissue [27].

Quantitativechanges in regional blood flow and metabolism resulting from SARS-CoV-2 and the associated InflammoThrombotic Response (ITR) can be non-invasively measured using FMTVDM. Increased FMTVDM values proceeding from 150 to 250 demonstrate progressive worsening of disease. Normal pulmonary tissue is associated with FMTVDM values of less than 150. 
The consistency between each of the three quantitative measures of FMTVDM, Ferritin and IL- 6 used throughout the study are demonstrated by the changes noted in Table 4 \& Figure 7. As shown FMTVDM provided the best measurement of CVD followed by IL- 6 and then Ferritin levels. The blood markers of ITR lagged behind tissue changes as shown in Table 4. Consequently treatment decisions were primarily determined by FMTVDM with clinicians able to include IL- 6 and Ferritin in their assessment of patients as treatments changed and decisions regarding intubation, extubation and hospital discharge were made. Treatments that resulted in an increase in FMTVDM of more than 25 were discontinued. Treatments that resulted in changes in FMTVDM of less than \pm 25 were continued and a new treatment was serially added to the regimen. Once FMTVDM decreased by $\geq$ than 25 or the value became less than 150, the patient's then current regimen was continued until completed.

Table 4: Quantitative changes in measured FMTVDM, Ferritin and IL-6 with inpatient treatment.

\begin{tabular}{|c|c|c|c|c|c|c|c|c|c|c|c|c|}
\hline $\begin{array}{l}\text { One-way ANOVA } \\
\text { Descriptive } \\
\text { Statistics }\end{array}$ & $\begin{array}{l}\text { Admis- } \\
\text { sion } \\
\text { FMTVDM }\end{array}$ & $\begin{array}{c}\text { Day } 4 \\
\text { FMTVDM }\end{array}$ & $\begin{array}{c}\text { Day } 7^{* *} \\
\text { FMTVDM }\end{array}$ & $\begin{array}{l}\text { Day } 10 * * * \\
\text { FMTVDM }\end{array}$ & $\begin{array}{l}\text { Admis- } \\
\text { sion Fer- } \\
\text { ritin }\end{array}$ & $\begin{array}{l}\text { Day } 4 \\
\text { Ferri- } \\
\text { tin }\end{array}$ & $\begin{array}{l}\text { Day } 7 \\
\text { Ferri- } \\
\text { tin }\end{array}$ & $\begin{array}{l}\text { Day } 10 \\
\text { Ferri- } \\
\text { tin }\end{array}$ & $\begin{array}{l}\text { Admis- } \\
\text { sion IL-6 }\end{array}$ & $\begin{array}{l}\text { Day } 4 \\
\text { IL-6 }\end{array}$ & $\begin{array}{l}\text { Day } 7 \\
\text { IL-6 }\end{array}$ & $\begin{array}{c}\text { Day } \\
10 \\
\text { IL-6 }\end{array}$ \\
\hline Number (n) & 501 & 501 & 235 & 29 & 501 & 501 & 235 & 29 & 501 & 501 & $234^{*}$ & 29 \\
\hline Mean (Average) & 198.6 & 159 & 129 & 119.9 & 656.9 & 468.2 & 322.2 & 286.7 & 55.7 & 33.13 & 20.4 & 17.8 \\
\hline $\begin{array}{l}\text { Standard Devia- } \\
\text { tion (S.D.) \# }\end{array}$ & 23.8 & 40.8 & 28.3 & 15.8 & 204.1 & 213.6 & 141.5 & 69.3 & 15.8 & 20.8 & 14.2 & 6.6 \\
\hline $\begin{array}{l}\text { Standard Error of } \\
\text { Mean (S.E.) }\end{array}$ & 1.06 & 1.8 & 1.8 & 2.9 & 9.1 & 9.5 & 9.2 & 12.86 & 0.7 & 0.9 & 0.9 & 1.2 \\
\hline $\begin{array}{l}\text { Lower } 95 \% \text { Con- } \\
\text { fidence Interval } \\
\text { (CI) }\end{array}$ & 196.5 & 155.5 & 125.4 & 113.9 & 639 & 449.5 & 304.1 & 260.3 & 54.3 & 31.3 & 18.6 & 15.3 \\
\hline Upper 95\% CI & 200.7 & 162.6 & 132.7 & 125.9 & 674.8 & 486.8 & 340.5 & 313 & 57.1 & 25 & 22.3 & 20.3 \\
\hline
\end{tabular}

Note: \# S.D. is the square root of variability.

${ }^{*}$ Missing data.

**46.9 \% (235 of 501) of patients required a second treatment based upon FMTVDM, Ferritin and IL-6 - either a single or combination treatment regimen.

$* * * 5.8 \%$ (29 of 501$)$ of patients required a third treatment based upon FMTVDM, Ferritin and IL- 6 - either a single or combination treatment regimen.

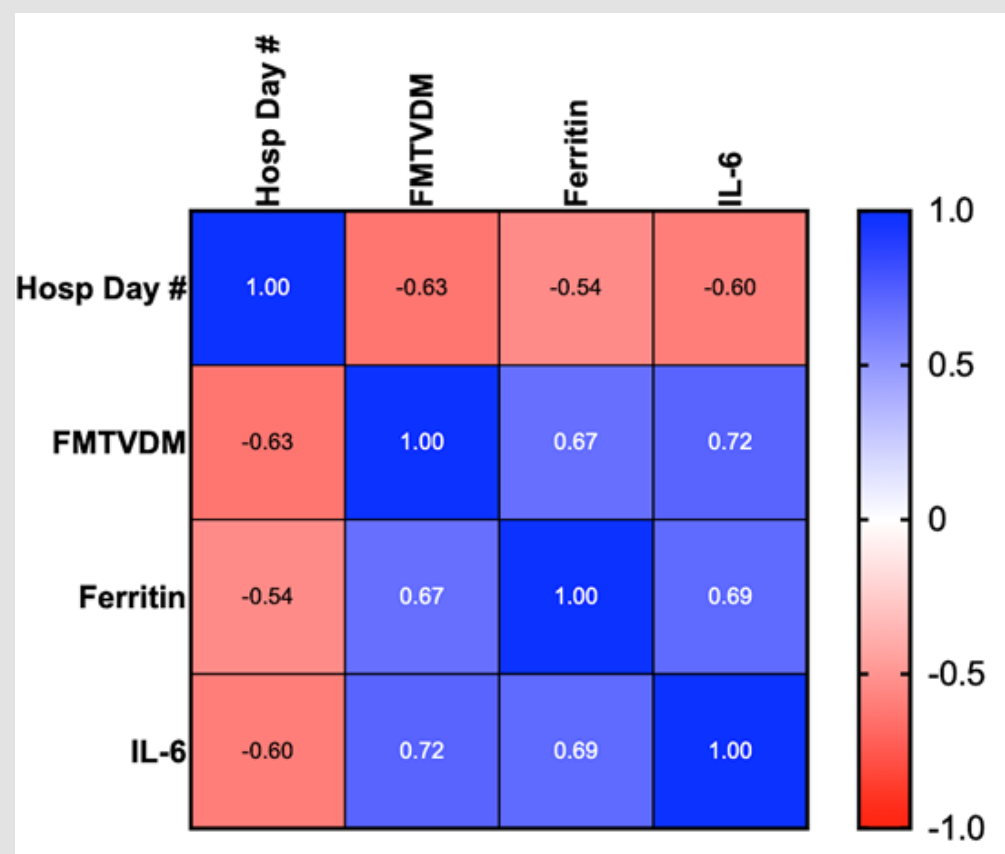

Figure 7: Correlation of Measured FMTVDM, Ferritin and IL-6.

Correlational changes seen between FMTVDM, Ferritin and IL-6 over the course of the study are shown in color scale with increased correlations as determined by Pearson's analysis as shown. The correlation between Ferritin and FMTVDM was 0.673 , and 0.718 between FMTVDM and IL-6. 


\section{Successful Treatment Outcomes for Inpatients}

Successful treatment outcomes were defined using the quantitative measurements of FMTVDM with a reduction of $\geq 25$, or a level of $\leq 150$, Ferritin levels $<270 \mathrm{ng} / \mathrm{ml}$ for men and $<160$ $\mathrm{ng} / \mathrm{ml}$ for women, and an IL-6 level of $<5 \mathrm{pg} / \mathrm{ml}$.

\section{Additional Diagnostic Studies}

12-lead electrocardiograms were obtained every three days with measurement of QTc intervals. The final analysis of any electrocardiogram and treatment decision was made by Cardiology. Additional telemetry monitoring provided interval monitoring and information. Additional blood work was routinely performed with morning labs except for the initial blood work obtained at the time of admission. In addition to Ferritin and IL-6 levels patients had daily CBCs with differential, liver and renal function along with fasting glucose levels. Due to the volume of blood obtained, venous samples were obtained in micro vacutainers. Additional testing was performed per hospital protocol.

\section{Medication Inpatient Treatment Arms}

During Phase I of the study patient treatment arms were different dependent upon whether the patient was intubated (Table 3B) and unable to take medications orally or not (Table 3A). Patients who were intubated and later extubated continued to receive the intubated medications to maintain consistency. Randomization of treatments was limited only by the exclusion of Treatment 5 from intubated patients, as Treatment 5 (Primaquine) is only available orally. One intubated patient was randomly assigned to treatment 5 and was subsequently re-randomized to another treatment group providing for intravenous administration of treatment. Additionally, convalescent plasma (Treatment 11) was not used as a first line treatment. It was included by randomized assignment as a second or third line treatment. Random assignment of Treatments was done at each site. Further medical treatment randomization was determined by the prior use of an aminoquinoline (hydroxychloroquine; HCQ) in the outpatient setting. Randomization for patients failing a HCQ prehospital treatment arm (Treatments 1-4) was to treatments arms 6 though 9. Failure to adequately respond based upon FMTVDM; Ferritin and IL-6 measurements resulted in the change or addition of yet another medical treatment randomly assigned including the inclusion of Treatment 11 (Convalescent Plasma). The process of continued serial addition of randomly selected medical treatments continued until treatment was successful or the patient expired.

Randomization of medical treatments for patients admitted without prior aminoquinoline (HCQ) treatment included assignment to treatment arms one through nine. Failure following initial inpatient treatment as defined resulted in additional randomization of treatment to be added to or in place of the initial treatment. This same sequence was continued until treatment was successful or the patient expired. Once a treatment arm for any study group failed it was abandoned and not used in that patient again. Finally in Phase II of the study, medications were combined (Figure 4) to augment treatment of the ITR based upon analysis of Phase I. During Phase II patients who failed outpatient aminoquinoline (HCQ) treatment were randomized to receive either Treatment 8 (Methylprednisolone) or a combination of agents including (a) Treatment 5 (Primaquine, Clindamycin), 7 (Tocilizumab) and 9 (Interferon $\alpha-2 \beta$ ), or (b) Treatments 7 (Tocilizumab) and 9 (Interferon $\alpha-2 \beta$ ). The same protocol was used for serial treatment decision-making. Patients who had not received outpatient treatment were randomized either to one of these three regimens as well as possible randomization to receive Treatment 4 (Hydroxychloroquine, Clindamycin and Primaquine) or Treatment 5 (Primaquine, Clindamycin).

\section{Other Treatments}

In addition to these treatments, patients also received immune support and bronchodilator treatment according to their treatment schedules in Tables 3A or 3B. Further treatments were determined by other medications the patients might have already been receiving or required by hospital protocol. The use of Esmolol [5] for heart rate and QTc regulation was determined by Cardiology. Patients were also given 5000 units of subcutaneous Heparin every 12-hours to reduce formation of thrombi. This agent was selected over other anticoagulants due to the easy of reversal with Protamine Sulfate within minutes .

\section{Oxygen and Respiratory Support}

Every effort was made to avoid intubation and reduce further ARDS $[3,4]$. When ventilators were used the tidal volume was restricted to $5 \mathrm{cc} / \mathrm{kg}$ Ideal Body Weight (IDW) with use of paralytic agents to prevent the patient from over breathing the ventilator. Per protocol other modalities included prone positioning, supplemental oxygen and Extracorporeal Membrane Oxygenation (ECMO) were given priority as shown in Table 5.

\section{Establishing A Covid-19 In Hospital Treatment Team}

In recognition of the complexity of treating a previously unknown viral infection and in recognition of the InflammoThrombotic Response (ITR) occurring in those hospitalized with CoVid-19, NCT04349410 required identification of a seven-person SARSCoV-2 treatment team. Their roles as team members are as defined:

Principle Responsibilities - It is critical that all members of the team know what each of the other members of the team are doing.

\section{Infectious Disease Physician}

Primarily responsible for treating SARS-CoV-2 infection and addressing secondary infections. 


\section{Cardiologist}

Maintain the satisfactory patient rhythm and address any electrolyte and QTC abnormalities focusing on the use of $\beta-1$ selective agonist [5]. Attention to be given to complement cascade clotting and glycoprotein IIb/IIIa issues resulting from ITR. The Cardiologist is also to be at the patient's bedside when adenosine is delivered during FMTVDM imaging.

\section{ICU-Pulmonologist}

Guarantee adequate oxygenation, control of ventilator tidal volumes, prone positioning, nebulizer treatments including Atrovent and any other medications, provided by nebulizer. The ICU-Pulmonologist is responsible for determining intubation and extubation of patients.

\section{Respiratory Technologist. [31]}

Responsible for any and all nebulizer treatments (Tables 3A \& 3B) including Atrovent.

\section{Pharmacist}

Guarantee that all medications are properly prepared with instructions for the rate of delivery and any and all monitoring needed to assure the safest and most effective delivery of the medications.

\section{ICU Nurse and Staff}

Guarantee that all medications are delivered according to instructions and not on an alternate delivery (e.g. q 8 hours, means every 8-hours, not three times a day).

\section{Nuclear Technologist}

Guarantee that all nuclear cameras are quantitatively calibrated at the beginning of the day. Make certain each patient's FMTVDM study falls at the same time of the patient's treatment regimen eliminating differences due to medications, movement, et cetera.

\section{Others}

Additional clinical personnel including Gastroenterologists, Nephrologists and Endocrinologists, along with ancillary personnel should be added to the SARS-CoV-2 clinical staff should patients have gastrointestinal, renal, or specific diabetic needs or concerns.

\section{Statistical Analysis}

Analysis of results included descriptive statistics including mean \pm standard deviations, Confidence Intervals (CI), range, and analysis between groups and group effects using student T-testing, Pearson's correlation, and one-way analysis of variance (ANOVA) using both Tukey and Bonferoni analysis for a more conservative analysis with statistical correction using Bartlett's statistic. Statistical analysis was conducted according to Snedecor and Cochran [32] using PRISM software [33] and graphing.

\section{Results}

From 16 April 2020 through 5 August 2020, 1800 study participants seen by clinicians in 7 countries and 23 study sites who tested positive for SARS-CoV-2 by PCR were enrolled for evaluation and treatment of SARS-CoV-2 and the ITR to the virus as shown in Table 1 . Tables $1 \& 2$ show the demographics of these individuals including $70.1 \%$ men and $29.9 \%$ women with an average age of $59 \pm 19$ years

\section{Outpatient Outcomes}

As patients entered the study, Figure 2 shows that they were initially seen as outpatients and divided into two groups. The first group of 847 (47\%) people included those whose clinicians did not think they required treatment. Of these 504 (59.5\%) were determined to be recovering on follow up evaluation 3-5 days later. Three hundred and forty-three (40.5\%) showed clinical deterioration requiring admission to hospital for treatment. Of these 301 were enrolled in Phase I of the study accounting for $88.5 \%$ of Phase I patients, with 42 enrolled in Phase II of the study accounting for $26.1 \%$ of the Phase II participants. Tables $1 \& 2$ show the demographics of these patients along with the severity of their admission measurements (FMTVDM, Ferritin, IL-6) of SARS-CoV-2.

The second group of people included those who received oneof-four outpatient treatment regimens by their clinicians after initial evaluation. These 953 patients represented $53 \%$ of the study participants. Of these 953, 795 (83.4 \%) were determined to have responded to outpatient treatment and were not admitted as shown in Tables $6 \& 11$. Analysis of these four different outpatient treatment regimens showed different response rates depending upon the combination of drugs used independent of supplemental zinc provided which as noted in the methods section included a minimum of $200 \mathrm{mg}$ of elemental zinc. The reported successful treatment response ranged from 74.2-100 \% depending upon the regimen. With the exception of Treatment 4 , which included a onetime dose of $200 \mathrm{mg}$ of Primaquine, the success rate as shown in Table 6 was 74.2 to $97.9 \%$. Among patients successfully treated as outpatients, Figure 2 shows the percentages following each of the four treatment groups that were deemed to have successfully responded to aminoquinoline outpatient treatment, including 28.3 $\%$ of cases from Treatment 1; $21.4 \%$ from Treatment 2; $23.8 \%$ from Treatment 3; and $26.5 \%$ from Treatment 4 including Primaquine. 
Table 5: Proven and proposed treatments based upon mechanism of action.

\begin{tabular}{|c|c|c|c|c|}
\hline Treatment & $\begin{array}{l}\text { Viral Attachment and } \\
\text { Replication }\end{array}$ & $\begin{array}{l}\text { Innate T-cell Cytotoxic Re- } \\
\text { sponse }\end{array}$ & Oxygenation and ARDS** & $\begin{array}{l}\text { Adaptive Humoral (Antibody) } \\
\text { Response. }\end{array}$ \\
\hline $\begin{array}{l}\text { 1,25-Dihydroxycho- } \\
\text { lecalciferol (Vit. D3) }\end{array}$ & & Improved immune response. & & Improved immune response. \\
\hline $\begin{array}{l}\text { Ascorbic Acid (Vit. } \\
\text { C) }\end{array}$ & & Improved immune response. & & Improved immune response \\
\hline Atrovent & & & $\begin{array}{l}\beta-2 \text { bronchodilator to in- } \\
\text { crease airway diameter and } \\
\text { reduce bronchial secretions } \\
\text { without the increase in } \\
\text { heart rate and potential QTc } \\
\text { prolongation associated } \\
\text { with b-1 agonists. }\end{array}$ & \\
\hline Azithromycin & $\begin{array}{l}\text { Inhibition of viral protein } \\
\text { translation. }\end{array}$ & & & \\
\hline Clindamycin & $\begin{array}{l}\text { Potential inhibitor of viral } \\
\text { attachment by inhibiting } \\
\text { Transmembrane protease } \\
\text { serine } 2 \text { (TMPRSS2). }\end{array}$ & & & \\
\hline Clindamycin & $\begin{array}{l}\text { Inhibition of viral protein } \\
\text { translation. }\end{array}$ & $\begin{array}{c}\text { Inhibits cytokine release } \\
\text { decreasing tissue necrosis } \\
\text { factor - alpha (TNF-a) and IL-1b } \\
\text { (Interleukin-1 beta). }\end{array}$ & & $\begin{array}{c}\text { Inhibits cytokine release decreas- } \\
\text { ing tissue necrosis factor - alpha } \\
\text { (TNF-a) and IL-1b (Interleukin-1 } \\
\text { beta). }\end{array}$ \\
\hline $\begin{array}{l}\text { Convalescent } \\
\text { Plasma }\end{array}$ & & & & $\begin{array}{l}\text { Provides passive immunity } \\
\text { reducing potential ITR although } \\
\text { the increased fibrinogen levels } \\
\text { associated with plasma trans- } \\
\text { fusions may increase thrombus } \\
\text { formation. }\end{array}$ \\
\hline $\begin{array}{l}\text { Cyanocobalamin } \\
\text { (Vit. B12) }\end{array}$ & & $\begin{array}{l}\text { Improved immune response } \\
\text { and reduction of inflammatory } \\
\text { homocysteine. }\end{array}$ & & $\begin{array}{l}\text { Improved immune response } \\
\text { and reduction of inflammatory } \\
\text { homocysteine. }\end{array}$ \\
\hline Doxycycline & $\begin{array}{l}\text { Inhibition of viral protein } \\
\text { translation. }\end{array}$ & & & \\
\hline Folate (Vit. B9) & & $\begin{array}{l}\text { Improved immune response } \\
\text { and reduction of inflammatory } \\
\text { homocysteine. }\end{array}$ & & $\begin{array}{l}\text { Improved immune response } \\
\text { and reduction of inflammatory } \\
\text { homocysteine. }\end{array}$ \\
\hline Hydroxychloroquine & $\begin{array}{l}\text { Inhibits viral RNA repli- } \\
\text { cation. }\end{array}$ & $\begin{array}{c}\text { Inhibits toll-like receptor } 7 \\
\text { (TLR7) to reduce inflammatory } \\
\text { response. }\end{array}$ & & $\begin{array}{l}\text { Inhibits glycoprotein IIb/IIIa } \\
\text { thereby interfering with throm- } \\
\text { bus formation. }\end{array}$ \\
\hline Hydroxychloroquine & $\begin{array}{l}\text { Inhibits viral attachment } \\
\text { at ACE2 receptor site. }\end{array}$ & $\begin{array}{l}\text { Reduces the production of } \\
\text { pro-inflammatory cytokines. }\end{array}$ & & \\
\hline Hydroxychloroquine & $\begin{array}{l}\text { Enhances entry of zinc } \\
\text { through zinc ionophore. }\end{array}$ & & & \\
\hline Hydroxychloroquine & $\begin{array}{l}\text { Increases cytosol pH to } \\
\text { reduce removal of viral } \\
\text { envelope required for } \\
\text { replication. }\end{array}$ & $\begin{array}{l}\text { Increases cellular pH decreas- } \\
\text { ing major histocompatability } \\
\text { complex (MHC) viral antigen } \\
\text { presentation to b-cells thereby } \\
\text { decreasing release of inflamma- } \\
\text { tory cytokines. }\end{array}$ & & \\
\hline Hydroxychloroquine & $\begin{array}{l}\text { Enhances production of } \\
\text { Type I Interferons. }\end{array}$ & & & \\
\hline Interferon $\mathrm{a}-2 \mathrm{~b}$ & $\begin{array}{l}\text { Interferes with viral rep- } \\
\text { lication. }\end{array}$ & Reduction of IL-6 levels. & & Reduction of IL- 6 levels. \\
\hline Losartan $^{* * *}$ & & & Potential to decrease ARDS. & \\
\hline Magnesium & & $\begin{array}{l}\text { Improved immune response } \\
\text { and reduction of QTc prolonga- } \\
\text { tion potential. }\end{array}$ & & $\begin{array}{l}\text { Improved immune response and } \\
\text { reduction of QTc prolongation } \\
\text { potential. }\end{array}$ \\
\hline Methylprednisolone & & & $\begin{array}{l}\text { Stimulates b-2 receptors } \\
\text { improving airway flow. }\end{array}$ & \\
\hline Methylprednisolone & & & $\begin{array}{l}\text { Decreases endothelial leak- } \\
\text { age producing ARDS. }\end{array}$ & \\
\hline
\end{tabular}




\begin{tabular}{|c|c|c|c|c|}
\hline Methylprednisolone & & Reduces IL-6 levels. & & Reduces IL-6 levels. \\
\hline $\begin{array}{l}\text { Oxygen (supple- } \\
\text { mental) other than } \\
\text { ventilator.* [Prone } \\
\text { positioning, BiPAP, } \\
\text { V-V ECMO, V-A } \\
\text { ECMO, NC, Venti } \\
\text { Mask.] }\end{array}$ & & & $\begin{array}{l}\text { Reduced inflammatory } \\
\text { stretching of alveoli and } \\
\text { subsequent worsening of } \\
\text { ARDS. }\end{array}$ & \\
\hline Primaquine & $\begin{array}{l}\text { Inhibits entry of Virulent } \\
\text { Newcastle Disease (VND) } \\
\text { virus. }\end{array}$ & & & \\
\hline Primaquine & $\begin{array}{l}\text { Inhibits viral RNA replica- } \\
\text { tion and protein transla- } \\
\text { tion. }\end{array}$ & & & \\
\hline Pyridoxine (Vit. B6) & & $\begin{array}{l}\text { Improved immune response } \\
\text { and reduction of inflammatory } \\
\text { homocysteine. }\end{array}$ & & $\begin{array}{l}\text { Improved immune response } \\
\text { and reduction of inflammatory } \\
\text { homocysteine. }\end{array}$ \\
\hline Remdesivir & $\begin{array}{l}\text { Interferes with formation } \\
\text { of mRNA via RdRP.**** }\end{array}$ & & & \\
\hline Tocilizumab & & $\begin{array}{l}\text { Blocks IL-6 receptors reducing } \\
\text { ITR. }\end{array}$ & & $\begin{array}{c}\text { Blocks IL-6 receptors reducing } \\
\text { ITR. }\end{array}$ \\
\hline Zinc & $\begin{array}{l}\text { May reduce ACE2 receptor } \\
\text { activity. }\end{array}$ & & & \\
\hline Zinc & $\begin{array}{l}\text { Interferes with RdRP and } \\
\text { polyprotein transcription. }\end{array}$ & & & \\
\hline Zinc & & Improved immune response. & & Improved immune response. \\
\hline
\end{tabular}

Note: ${ }^{*} \mathrm{BiPAP}=$ Bilevel Positive Airway Pressure, $\mathrm{V}-\mathrm{V}$ is vein to vein, $\mathrm{V}-\mathrm{A}$ is vein to artery, ECMO $=$ extracorporeal membrane oxygenation, $\mathrm{NC}=$ nasal cannula, and Venti $=$ Venturi.

**Acute Respiratory Distress Syndrome.

*** Originally included in study design with prior pre-clinical studies in animals suggesting a possible mechanism of action inhibiting ARDS with H5N1 virus. Excluded from study after IRB review and consideration of concerns for angiotensin-converting-enzyme (ACE) inhibitors and angiotensin II receptor blockers (ARBs). Included in this table for completeness.

**** RdRP $=$ RNA dependent RNA polymerase.

Table 6: Hydroxychloroquine Success and Failure Rate leading to Admission.

\begin{tabular}{|c|c|c|c|c|c|c|}
\hline Total & $\begin{array}{c}\text { HCQ } \\
\text { Pre-hospital Treat- } \\
\text { ment Success }\end{array}$ & $\begin{array}{c}\text { HCQ Failures } \\
\text { entered } \\
\text { Phase I }\end{array}$ & $\begin{array}{c}\text { HCQ Failures } \\
\text { entered Phase } \\
\text { II }\end{array}$ & $\begin{array}{c}\text { Total Number of } \\
\text { Patients Treated with } \\
\text { HCQ }\end{array}$ & $\begin{array}{l}\text { Percent Success- } \\
\text { ful Treatment }\end{array}$ & $\begin{array}{l}\text { Percent Treat- } \\
\text { ment Failure }\end{array}$ \\
\hline Treatment 1 & 225 & 20 & 58 & 303 & $74.20 \%$ & $25.70 \%$ \\
\hline Treatment 2 & 170 & 17 & 59 & 246 & $69.10 \%$ & $30.90 \%$ \\
\hline Treatment 3 & 189 & 2 & 2 & 193 & $97.90 \%$ & $2.10 \%$ \\
\hline Treatment 4 & 211 & 0 & 0 & 211 & $100 \%$ & $0.00 \%$ \\
\hline
\end{tabular}

Upon re-evaluation 3-5 days later, 158 (16.6\%) of those who received outpatient aminoquinoline treatment were subsequently admitted to hospital with 39 enrolled in Phase I, and 119 in Phase II. The outpatient failures represented $11.5 \%$ of the Phase I patients and $73.9 \%$ of those in Phase II. Table 2 shows the severity of SARSCoV-2 upon admission for patients who did and did not receive outpatient therapy. There were no statistical differences between those who were admitted and failed aminoquinoline treatment and those who received no pre-hospital treatment. The results of the two groups are pooled together in Table 4. Outpatients did not undergo diagnostic measurement of FMTVDM, Ferritin or IL-6 to quantitatively measure treatment results. Their physicians subjectively determined their outcomes.

\section{Phase I outcomes-analysis of sequential single drug treatments added in queue.}

Of the 501 patients admitted to hospital, 340 (67.9\%) were enrolled in Phase I looking at the effect of sequentially adding single drug treatments to the single drug treatment started upon admission following diagnostic evaluation including FMTVDM, Ferritin, IL-6, 12-lead electrocardiograms, and additional blood work already noted. The measurement of QTc in all treatment groups including both Phase I and II did not compromise treatment algorithms and there were no reported cases of Torsades de pointes (TdP) or other ventricular dysrhythmias reported. Similarly Phase I, and II Treatments, were not altered due to glucose; liver and renal 
function tests, or QTc, and they consequently will not be discussed further here.

\section{Patients Who Failed Outpatient Aminoquinoline \\ Treatment}

As shown in Figure $2 \&$ Table 7, of the 340 patients enrolled in Phase I, 39 (11.5\%) of these were patients who failed outpatient aminoquinoline treatment. Roughly half (51.3 \%) had received Treatment $1,43.6 \%$ had received Treatment 2 , and $5.1 \%$ had received Treatment 3. None of the outpatients who received Treatment 4 containing Primaquine failed outpatient treatment. Of these 39 patients, 8 (20.5\%) received Treatment 6 (Remdesivir) as shown in Figure 2 \& Table 7. Five of the 8 (62.5 $\%$ responded successfully to treatment as defined by changes in FMTVDM, Ferritin and IL-6 levels. Of the three (37.5\%) that did not respond, the addition of Interferon $\alpha-2 \beta$ (Treatment 9) in 1 case, and Convalescent Plasma (Treatment 11) in two other cases produced successful treatment results in all three (100\%) cases. Ten (25.6\%) of the 39 received Treatment 7 (Tocilizumab) as a first line treatment following aminoquinoline failure, with 10 (100\%) of these patients responding favorably. Eleven (28.2\%) were successfully treated with Methylprednisolone (Treatment 8) without further treatment change. Of the remaining 10 (25.6 $\%$ ) who were received Treatment 9 (Interferon $\alpha-2 \beta$ ), $90 \%$ (9) responded to treatment, with $1(10 \%)$ responding to the addition of Methylprednisolone (Treatment 8). Of those admitted for further evaluation and treatment after failing outpatient aminoquinolines, 35 (89.7\%) responded to first line treatment including Remdesivir, Tocilizumab, Methylprednisolone and Interferon $\alpha-2 \beta$. Of the four (10.2\%) that required an additional line of treatment, 3 (75\%) of these were being treated with Remdesivir and 1 (25\%) with Interferon $\alpha-2 \beta$.

Table 7: Phase I Treatment Outcomes with Sequentially added Single Treatment Arms.

\begin{tabular}{|c|c|c|c|c|c|c|c|}
\hline $\begin{array}{c}\text { First In Hospital Treat- } \\
\text { ment Arm }\end{array}$ & Patient Group & $\begin{array}{l}\text { Number } \\
\text { Treated }\end{array}$ & $\begin{array}{c}\text { Successful } \\
\text { Treatment (\%) }\end{array}$ & $\begin{array}{l}\text { Secondary Treat- } \\
\text { ment (Tx) Added* }\end{array}$ & $\begin{array}{c}\text { Number Successful } \\
(\%)\end{array}$ & $\begin{array}{c}\text { Third Treatment } \\
\text { (Tx) Added }\end{array}$ & $\begin{array}{c}\text { Number Successful } \\
(\%)\end{array}$ \\
\hline \multirow{25}{*}{$\begin{array}{l}\text { (Hydroxychloroquine, } \\
\text { Azithromycin) }\end{array}$} & \multirow{25}{*}{$\begin{array}{l}\text { No pre-hospi- } \\
\text { tal treatment } \\
\text { patients }\end{array}$} & \multirow{25}{*}{38} & \multirow{25}{*}{$0(0 \%)$} & \multirow{5}{*}{ Tx 6: 5} & \multirow{5}{*}{$0(0 \%)$} & Tx 6: 0 & NA \\
\hline & & & & & & Tx 7: 2 & $2(100 \%)$ \\
\hline & & & & & & Tx 8: 3 & $3(100 \%)$ \\
\hline & & & & & & Tx 9: 0 & NA \\
\hline & & & & & & Tx 11: 0 & NA \\
\hline & & & & \multirow{5}{*}{ Tx 7: 11} & \multirow{5}{*}{$8(72.7 \%)$} & Tx 6: 0 & NA \\
\hline & & & & & & Tx 7: 0 & NA \\
\hline & & & & & & Tx 8: 2 & $2(100 \%)$ \\
\hline & & & & & & Tx 9: 0 & NA \\
\hline & & & & & & Tx 11: 1 & $1(100 \%)$ \\
\hline & & & & \multirow{5}{*}{ M: 10} & \multirow{5}{*}{$8(80 \%)$} & Tx 6: 0 & NA \\
\hline & & & & & & Tx 7: 1 & $1(100 \%)$ \\
\hline & & & & & & Tx 8: 0 & NA \\
\hline & & & & & & Tx 9: 1 & $1(100 \%)$ \\
\hline & & & & & & Tx 11: 0 & NA \\
\hline & & & & \multirow{5}{*}{ I: 7} & \multirow{5}{*}{$6(85.7 \%)$} & Tx 6: 0 & NA \\
\hline & & & & & & Tx 7: 0 & NA \\
\hline & & & & & & Tx 8: 0 & NA \\
\hline & & & & & & Tx 9: 0 & NA \\
\hline & & & & & & Tx 11: 1 & $1(100 \%)$ \\
\hline & & & & \multirow{5}{*}{ P: 5} & \multirow{5}{*}{$5(100 \%)$} & Tx 6: 0 & NA \\
\hline & & & & & & Tx 7: 0 & NA \\
\hline & & & & & & Tx 8: 0 & NA \\
\hline & & & & & & Tx 9: 0 & NA \\
\hline & & & & & & Tx 11: 0 & NA \\
\hline \multicolumn{4}{|c|}{ Totals } & 38 & 27 (71 \%) & 11 & $11(100 \%)$ \\
\hline
\end{tabular}




\begin{tabular}{|c|c|c|c|c|c|c|c|}
\hline \multirow{25}{*}{$\begin{array}{c}\text { (Hydroxychloroquine, } \\
\text { Doxycycline) }\end{array}$} & \multirow{25}{*}{$\begin{array}{l}\text { No pre-hospi- } \\
\text { tal treatment } \\
\text { patients }\end{array}$} & \multirow{25}{*}{29} & \multirow{25}{*}{$0(0 \%)$} & \multirow{5}{*}{ Tx 6: 3} & \multirow{5}{*}{$0(0 \%)$} & Tx 6: 0 & NA \\
\hline & & & & & & Tx 7: 0 & NA \\
\hline & & & & & & Tx 8: 2 & $2(100 \%)$ \\
\hline & & & & & & Tx 9: 0 & NA \\
\hline & & & & & & Tx 11: 1 & $1(100 \%)$ \\
\hline & & & & \multirow{5}{*}{ Tx 7: 4} & \multirow{5}{*}{$2(50 \%)$} & Tx 6: 0 & NA \\
\hline & & & & & & Tx 7: 0 & NA \\
\hline & & & & & & Tx 8: 0 & NA \\
\hline & & & & & & Tx 9: 2 & $2(100 \%)$ \\
\hline & & & & & & Tx 11: 0 & NA \\
\hline & & & & \multirow{5}{*}{ Tx 8: 10} & \multirow{5}{*}{7 (70 \%) } & Tx 6: 0 & NA \\
\hline & & & & & & Tx 7: 1 & $1(100 \%)$ \\
\hline & & & & & & Tx 8: 0 & NA \\
\hline & & & & & & Tx 9: 1 & $1(100 \%)$ \\
\hline & & & & & & Tx 11: 1 & $1(100 \%)$ \\
\hline & & & & \multirow{5}{*}{ Tx 9: 11} & \multirow{5}{*}{$9(81.8 \%)$} & Tx 6: 0 & NA \\
\hline & & & & & & Tx 7: 1 & $1(100 \%)$ \\
\hline & & & & & & Tx 8: 1 & $1(100 \%)$ \\
\hline & & & & & & Tx 9: 0 & NA \\
\hline & & & & & & Tx 11: 0 & NA \\
\hline & & & & \multirow{5}{*}{$P: 1$} & \multirow{5}{*}{$1(100 \%)$} & Tx 6: 0 & NA \\
\hline & & & & & & Tx 7: 0 & NA \\
\hline & & & & & & Tx 8: 0 & NA \\
\hline & & & & & & Tx 9: 0 & NA \\
\hline & & & & & & Tx 11: 0 & NA \\
\hline \multicolumn{4}{|c|}{ Totals } & 29 & $19(65.5 \%)$ & 10 & $10(100 \%)$ \\
\hline \multirow{12}{*}{ Treatment 3} & \multirow{25}{*}{$\begin{array}{l}\text { No pre-hospi- } \\
\text { tal treatment } \\
\text { patients }\end{array}$} & \multirow{25}{*}{25} & \multirow{25}{*}{$(0 \%)$} & & & Tx 6: 0 & NA \\
\hline & & & & & & Tx 7: 0 & NA \\
\hline & & & & Tx 6: 0 & NA & Tx 8: 0 & NA \\
\hline & & & & & & Tx 9: 0 & NA \\
\hline & & & & & & Tx 11: 0 & NA \\
\hline & & & & & & Tx 6: 0 & NA \\
\hline & & & & & & Tx 7: 0 & NA \\
\hline & & & & Tx 7: 10 & $8(80 \%)$ & Tx 8: 1 & $1(100 \%)$ \\
\hline & & & & & & Tx 9: 0 & NA \\
\hline & & & & & & Tx 11: 1 & $1(100 \%)$ \\
\hline & & & & & & Tx 6: 0 & NA \\
\hline & & & & & & Tx 7: 0 & NA \\
\hline $\begin{array}{l}\text { (Hyaroxycnioroquine, } \\
\text { Clindamycin) }\end{array}$ & & & & Tx 8: 6 & $6(100 \%)$ & Tx 8: 0 & NA \\
\hline & & & & & & Tx 9: 0 & NA \\
\hline & & & & & & Tx 11: 0 & NA \\
\hline NO PRIMAQUINE & & & & & & Tx 6: 0 & NA \\
\hline & & & & & & Tx 7: 0 & NA \\
\hline & & & & Tx 9: 9 & $8(88.9 \%)$ & Tx 8: 1 & $1(100 \%)$ \\
\hline & & & & & & Tx 9: 0 & NA \\
\hline & & & & & & Tx 11: 0 & NA \\
\hline & & & & & & Tx 6: 0 & NA \\
\hline & & & & & & Tx 7: 0 & NA \\
\hline & & & & Tx 11: 0 & NA & Tx 8: 0 & NA \\
\hline & & & & & & Tx 9: 0 & NA \\
\hline & & & & & & Tx 11: 0 & NA \\
\hline & Totals & & & 25 & $22(88 \%)$ & 3 & $3(100 \%)$ \\
\hline
\end{tabular}




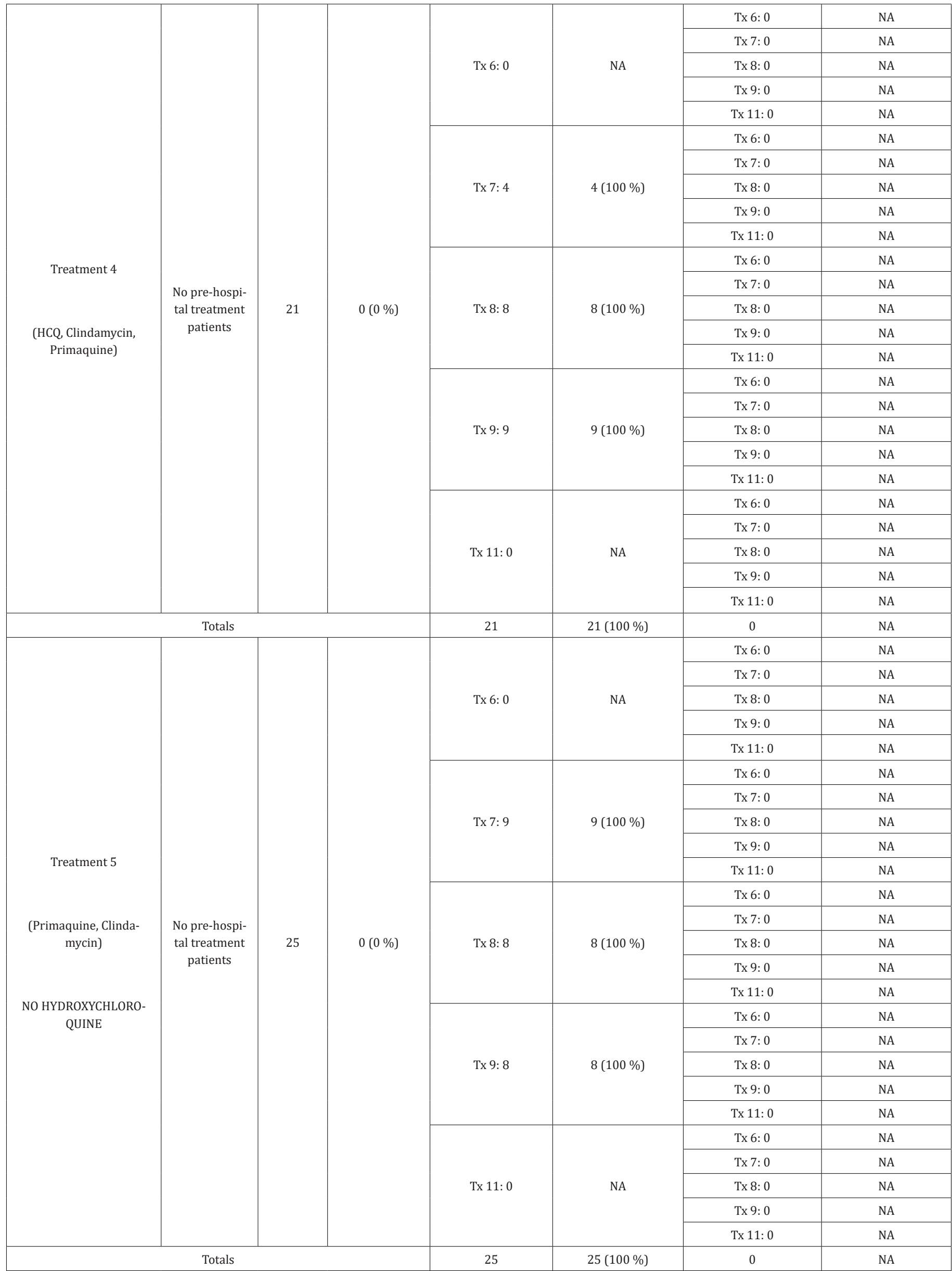




\begin{tabular}{|c|c|c|c|c|c|c|c|}
\hline \multirow[b]{4}{*}{ (Remdesivir) } & \multirow{4}{*}{$\begin{array}{c}\text { HCQ failure } \\
\text { patients }\end{array}$} & \multirow{4}{*}{8} & \multirow{4}{*}{$5(62.5 \%)$} & Tx 7: 0 & NA & & \\
\hline & & & & Tx 8: 0 & NA & & \\
\hline & & & & Tx 9: 1 & 1 of $1(100 \%)$ & & \\
\hline & & & & Tx 11: 2 & 2 of $2(100 \%)$ & & \\
\hline & \multirow{25}{*}{$\begin{array}{l}\text { No pre-hospi- } \\
\text { tal treatment } \\
\text { patients }\end{array}$} & \multirow{25}{*}{39} & \multirow{25}{*}{$\begin{array}{c}1 \text { Death from } 39 \\
\text { patients. }\end{array}$} & \multirow{5}{*}{ Tx 6: NA } & \multirow{5}{*}{ NA } & Tx 6: 0 & NA \\
\hline & & & & & & Tx 7: 0 & NA \\
\hline & & & & & & Tx 8: 0 & NA \\
\hline & & & & & & Tx 9: 0 & NA \\
\hline & & & & & & Tx 11: 0 & NA \\
\hline & & & & \multirow{5}{*}{ Tx 7: 7} & \multirow{5}{*}{$4(57.1 \%)$} & Tx 6: 0 & NA \\
\hline & & & & & & Tx 7: 0 & NA \\
\hline & & & & & & Tx 8: 0 & NA \\
\hline & & & & & & Tx 9: 3 & $3(100 \%)$ \\
\hline & & & & & & Tx 11: 0 & NA \\
\hline & & & & \multirow{5}{*}{ Tx 8: 6} & \multirow{5}{*}{$5(83.3 \%)$} & Tx 6: 0 & NA \\
\hline & & & & & & Tx 7: 0 & NA \\
\hline & & & & & & Tx 8: 0 & NA \\
\hline & & & & & & Tx 9: 1 & $1(100 \%)$ \\
\hline & & & & & & Tx 11: 0 & NA \\
\hline & & & & \multirow{5}{*}{ Tx 9: 6} & \multirow{5}{*}{$5(83.3 \%)$} & Tx 6: 0 & NA \\
\hline & & & & & & Tx 7: 1 & $1(100 \%)$ \\
\hline & & & & & & Tx 8: 0 & NA \\
\hline & & & & & & Tx 9: 0 & NA \\
\hline & & & & & & Tx 11: 0 & NA \\
\hline & & & & \multirow{5}{*}{ Tx 11: 8} & \multirow{5}{*}{$8(100 \%)$} & Tx 6: 0 & NA \\
\hline & & & & & & Tx 7: 0 & NA \\
\hline & & & & & & Tx 8: 0 & NA \\
\hline & & & & & & Tx 9: 0 & NA \\
\hline & & & & & & Tx 11: 0 & NA \\
\hline & \multirow{25}{*}{$\begin{array}{l}\text { Total of Both } \\
\text { Groups }\end{array}$} & & & & & Tx 6: 0 & NA \\
\hline & & & & & & Tx 7: 0 & NA \\
\hline & & & & Tx 6: NA & NA & Tx 8: 0 & NA \\
\hline & & & & & & Tx 9: 0 & NA \\
\hline & & & & & & Tx 11: 0 & NA \\
\hline & & & & & & Tx 6: 0 & NA \\
\hline & & & & & & Tx 7: 0 & NA \\
\hline & & & $16(34.0 \%)$ & Tx 7: 7 & $4(57.1 \%)$ & Tx 8: 0 & NA \\
\hline & & & & & & Tx 9: 3 & $3(100 \%)$ \\
\hline & & & 1. Death from 47 & & & Tx 11: 0 & NA \\
\hline & & & & & & Tx 6: 0 & NA \\
\hline & & & $(2.1 \%)$ & & & Tx 7: 0 & NA \\
\hline & & 47 & & Tx 8: 6 & $5(83.3 \%)$ & Tx 8: 0 & NA \\
\hline & & & & & & Tx 9: 1 & $1(100 \%)$ \\
\hline & & & & & & Tx 11: 0 & NA \\
\hline & & & & & & Tx 6: 0 & NA \\
\hline & & & & & & Tx 7: 1 & $1(100 \%)$ \\
\hline & & & & Tx 9: 7 & $6(85.7 \%)$ & Tx 8: 0 & NA \\
\hline & & & & & & Tx 9: 0 & NA \\
\hline & & & & & & Tx 11: 0 & NA \\
\hline & & & & & & Tx 6: 0 & NA \\
\hline & & & & & & Tx 7: 0 & NA \\
\hline & & & & Tx 11: 10 & 10 (100\%) & Tx 8: 0 & NA \\
\hline & & & & & & Tx 9: 0 & NA \\
\hline & & & & & & Tx 11: 0 & NA \\
\hline
\end{tabular}




\begin{tabular}{|c|c|c|c|c|c|c|c|}
\hline \multicolumn{4}{|c|}{ Totals } & 30 & $25(83.3 \%)$ & 5 & $5(100 \%)$ \\
\hline \multicolumn{8}{|c|}{ DEATH: 1 (Hospital Day 4 - On Ventilator) } \\
\hline \multirow[b]{4}{*}{ (Tocilizumab) } & \multirow{4}{*}{$\begin{array}{l}\text { HCQ failure } \\
\text { patients }\end{array}$} & \multirow{4}{*}{10} & \multirow{4}{*}{$10(100 \%)$} & Tx 6: 0 & NA & & \\
\hline & & & & Tx 8: 0 & NA & & \\
\hline & & & & Tx 9: 0 & NA & & \\
\hline & & & & Tx 11: 0 & NA & & \\
\hline & \multirow{25}{*}{$\begin{array}{l}\text { No pre-hospi- } \\
\text { tal treatment } \\
\text { patients }\end{array}$} & \multirow{25}{*}{39} & \multirow{14}{*}{$14(35.9 \%)$} & \multirow{5}{*}{$\mathrm{R}: 3$} & \multirow{5}{*}{$3(100 \%)$} & Tx 6: 0 & NA \\
\hline & & & & & & Tx 7: 0 & NA \\
\hline & & & & & & Tx 8: 0 & NA \\
\hline & & & & & & Tx 9: 0 & NA \\
\hline & & & & & & Tx 11: 0 & NA \\
\hline & & & & \multirow{5}{*}{ T: NA } & \multirow{5}{*}{ NA } & Tx 6: 0 & NA \\
\hline & & & & & & Tx 7: 0 & NA \\
\hline & & & & & & Tx 8: 0 & NA \\
\hline & & & & & & Tx 9: 0 & NA \\
\hline & & & & & & Tx 11: 0 & NA \\
\hline & & & & \multirow{5}{*}{ M: 2} & \multirow{5}{*}{$2(100 \%)$} & Tx 6: 0 & NA \\
\hline & & & & & & Tx 7: 0 & NA \\
\hline & & & & & & Tx 8: 0 & NA \\
\hline & & & & & & Tx 9: 0 & NA \\
\hline & & & \multirow{3}{*}{$\begin{array}{c}1 \text { Death of } 39 \\
\text { patients. }\end{array}$} & & & Tx 11: 0 & NA \\
\hline & & & & \multirow{5}{*}{ I: 8} & \multirow{5}{*}{$8(100 \%)$} & Tx 6: 0 & NA \\
\hline & & & & & & Tx 7: 0 & NA \\
\hline & & & \multirow[t]{8}{*}{$(2.6 \% \%)$} & & & Tx 8: 0 & NA \\
\hline & & & & & & Tx 9: 0 & NA \\
\hline & & & & & & Tx 11: 0 & NA \\
\hline & & & & & & Tx 6: 0 & NA \\
\hline & & & & & & Tx 7: 0 & NA \\
\hline & & & & P: 11 & $11(100 \%)$ & Tx 8: 0 & NA \\
\hline & & & & & & Tx 9: 0 & NA \\
\hline & & & & & & Tx 11: 0 & NA \\
\hline
\end{tabular}




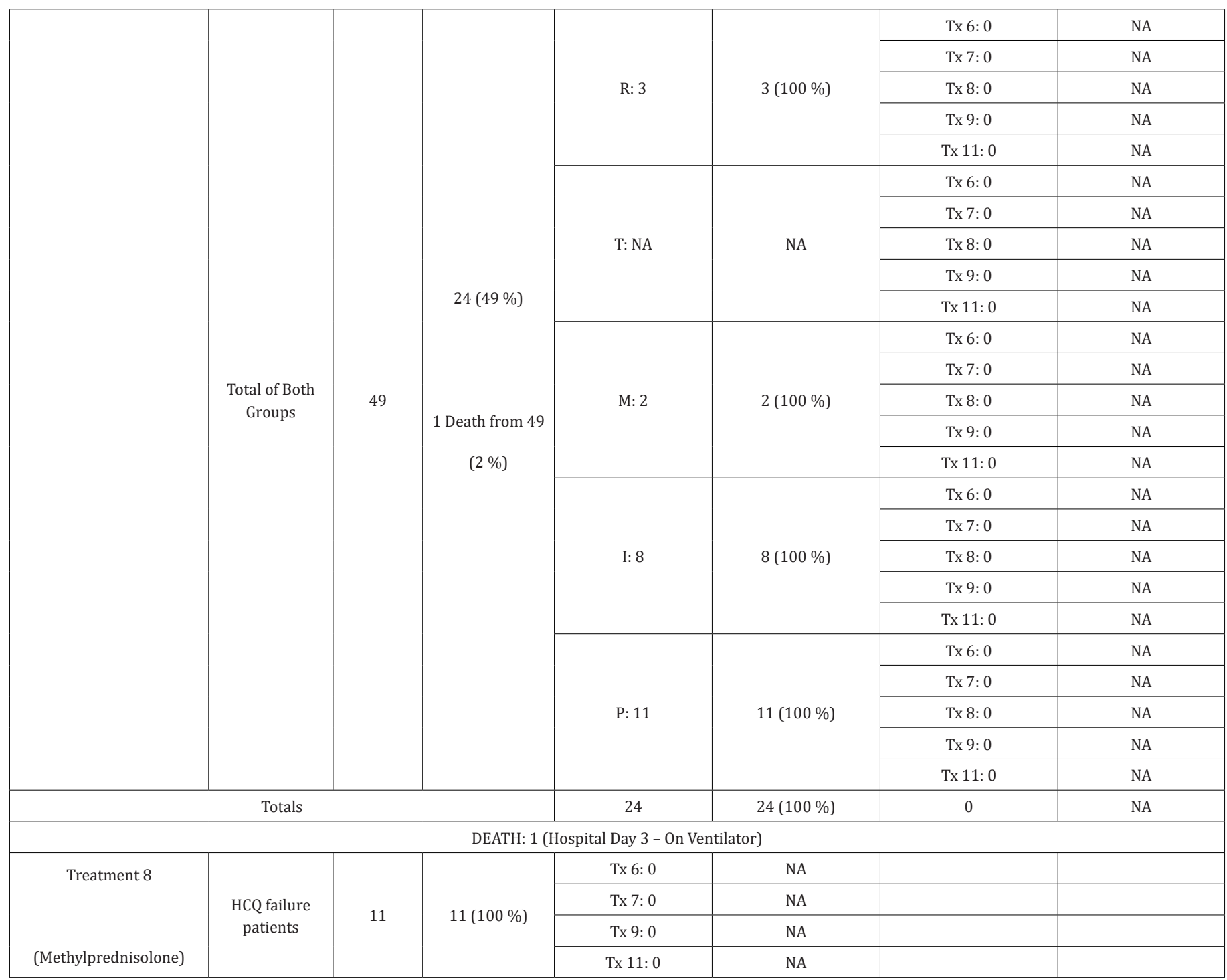




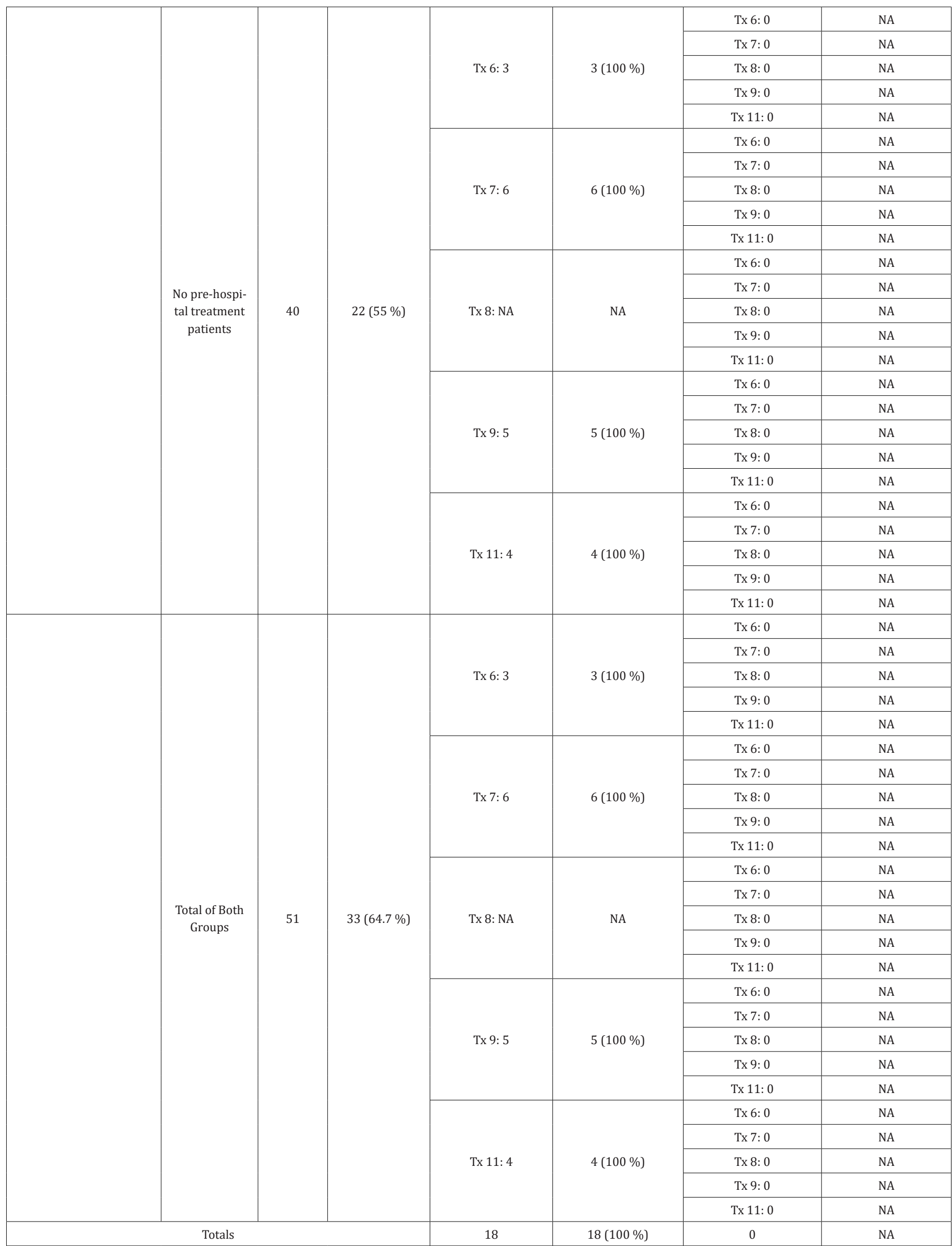




\begin{tabular}{|c|c|c|c|c|c|c|c|}
\hline \multirow[b]{4}{*}{ (Interferon $\mathrm{a}-2 \mathrm{~b}$ ) } & \multirow{4}{*}{$\begin{array}{c}\text { HCQ failure } \\
\text { patients }\end{array}$} & \multirow{4}{*}{10} & \multirow{4}{*}{$9(90 \%)$} & Tx 6: 0 & NA & & \\
\hline & & & & Tx 7: 0 & NA & & \\
\hline & & & & Tx 8: 1 & $1(100 \%)$ & & \\
\hline & & & & Tx 11: 0 & NA & & \\
\hline & \multirow{25}{*}{$\begin{array}{l}\text { No pre-hospi- } \\
\text { tal treatment } \\
\text { patients }\end{array}$} & \multirow{25}{*}{45} & \multirow{25}{*}{$32(71.1 \%)$} & \multirow{5}{*}{ Tx 6: 1} & \multirow{5}{*}{$1(100 \%)$} & Tx 6: 0 & NA \\
\hline & & & & & & Tx 7: 0 & NA \\
\hline & & & & & & Tx 8: 0 & NA \\
\hline & & & & & & Tx 9: 0 & NA \\
\hline & & & & & & Tx 11: 0 & NA \\
\hline & & & & \multirow{5}{*}{ Tx 7: 5} & \multirow{5}{*}{$5(100 \%)$} & Tx 6: 0 & NA \\
\hline & & & & & & Tx 7: 0 & NA \\
\hline & & & & & & Tx 8: 0 & NA \\
\hline & & & & & & Tx 9: 0 & NA \\
\hline & & & & & & Tx 11: 0 & NA \\
\hline & & & & \multirow{5}{*}{ Tx 8: 3} & \multirow{5}{*}{$3(100 \%)$} & Tx 6: 0 & NA \\
\hline & & & & & & Tx 7: 0 & NA \\
\hline & & & & & & Tx 8: 0 & NA \\
\hline & & & & & & Tx 9: 0 & NA \\
\hline & & & & & & Tx 11: 0 & NA \\
\hline & & & & \multirow{5}{*}{ Tx 9: NA } & \multirow{5}{*}{ NA } & Tx 6: 0 & NA \\
\hline & & & & & & Tx 7: 0 & NA \\
\hline & & & & & & Tx 8: 0 & NA \\
\hline & & & & & & Tx 9: 0 & NA \\
\hline & & & & & & Tx 11: 0 & NA \\
\hline & & & & \multirow{5}{*}{ Tx 11: 4} & \multirow{5}{*}{$4(100 \%)$} & Tx 6: 0 & NA \\
\hline & & & & & & Tx 7: 0 & NA \\
\hline & & & & & & Tx 8: 0 & NA \\
\hline & & & & & & Tx 9: 0 & NA \\
\hline & & & & & & Tx 11: 0 & NA \\
\hline
\end{tabular}




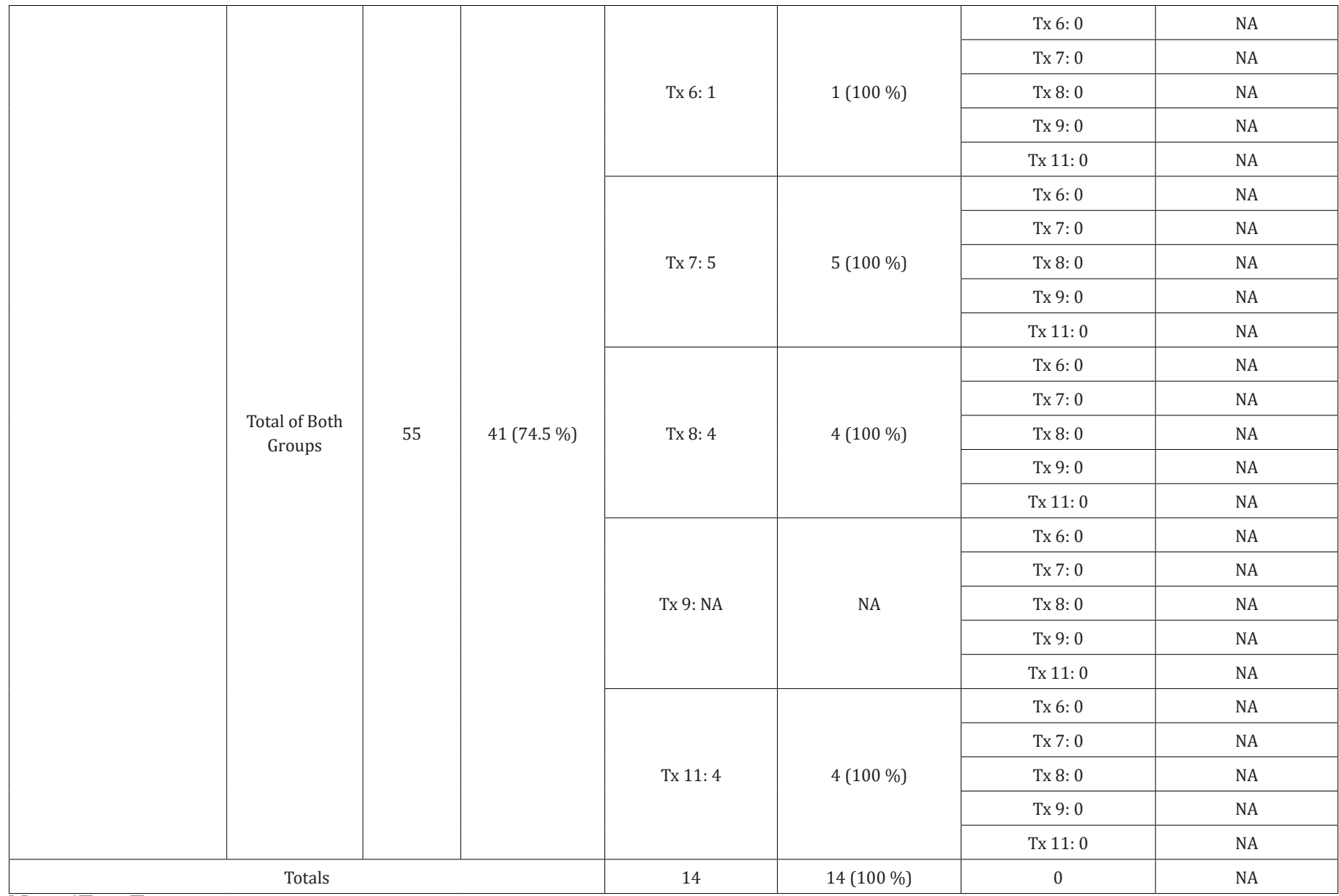

Note: ${ }^{*} \mathrm{Tx}=$ Treatment

Treatment 1 - Hydroxychloroquine, Azithromycin;

Treatment 2 - Hydroxychloroquine, Doxycycline;

Treatment 3 - Hydroxychloroquine, Clindamycin - No Primaquine;

Treatment 4 - Hydroxychloroquine, Clindamycin, Primaquine;

Treatment 5 - Primaquine, Clindamycin - No Hydroxychloroquine;

Treatment 6 - Remdesivir;

Treatment 7 - Tocilizumab;

Treatment 8 - Methylprednisolone;

Treatment 9 - Interferon $\mathrm{a}-2 \mathrm{~b}$ and

Treatment 11 - Convalescent Plasma

\section{Patients Who Received No Outpatient Treatment}

Figures $2 \& 3$ and Table 7 show the flow and treatment results of patients who were enrolled in Phase I of the study after failing to improve as outpatients without treatment. As shown in Figure 2, 301 (88.5 \%) of the Phase I patients were individuals who had received no outpatient treatment and were admitted to hospital for further evaluation and treatment. This group of patients is further detailed in Figures 3 \& Table 7. Patients enrolled without prior outpatient treatment were randomly assigned to one of nine first line treatments, and one of ten when more than one treatment was added to the treatment regimen. This tenth treatment was defined as Treatment 11 (Convalescent Plasma). The original tenth treatment (Losartan) noted in Table 5 was thought to have a potential benefit based upon animal models but was excluded by the IRB given concerns about the potential increase in ACE2 receptors and lack of further potential information when the study was initiated.

Of the 301 patients in this part of Phase I, 38 (12.6\%) were randomly assigned to Treatment 1 (Hydroxychloroquine, Azithromycin). None of the patients showed a measureable treatment response. Of these 38, 5 (13.2\%) received Remdesivir (Treatment 6) as a second line drug, with none of the patients responding to the addition of Remdesivir. These same 5 patients then went on to receive a third drug, including 2 who responded to Treatment 7 (Tocilizumab) and 3 who responded to Treatment 8 (Methylprednisolone). Eleven (28.9\%) of the 38 patients who failed 
first line treatment with Treatment 1, where given Tocilizumab (Treatment 7) as their second drug. Of these 11 patients, 8 (72.7 $\%)$ responded and three required the addition of a third drug; including two who received Treatment 8 (Methylprednisolone) and one who received Convalescent Plasma (Treatment 11). All three of these patients responded to treatment. Methylprednisolone (Treatment 8 ) was given to $10(26.3 \%)$ of those who failed to respond to Treatment 1 . Eight ( $80 \%$ ) of these patients responded to Methylprednisolone leaving only 2 to require a third drug including one who received Treatment 7 (Tocilizumab) and one who received Treatment 9 (Interferon $\alpha-2 \beta$ ) - both patients responded to this third drug treatment.

Seven (18.4\%) of these patients received Interferon $\alpha-2 \beta$ (Treatment 9) as their second drug with 6 (85.7\%) of them responding. The remaining patient responded with Convalescent Plasma (Treatment 11). Five (13.2\%) of these patients received Convalescent Plasma (Treatment 11) as their second drug - all five $(100 \%)$ favorably responded to treatment. Of the 38 patients, no one responded to the initial treatment with Treatment 1 (Hydroxychloroquine, Azithromycin). Twenty-seven (71 \%) responded to the addition of a second drug and the remaining 11 people successfully responded to addition of a third drug. Twentynine $(9.6 \%)$ of the 301 patients admitted without prior outpatient treatment were first given Treatment 2 (Hydroxychloroquine, Doxycycline). None of these 29 patients responded to this as the initial drug treatment. Of these 29 patients, 3 (10.3\%) were randomly assigned to receive Remdesivir. None of the three patients responded; however, all three responded to the addition of a third drug including two who responded to Treatment 8 (Methylprednisolone) and one who responded to Convalescent Plasma (Treatment 11).

Four (13.8\%) of the 29 patients received Treatment 7 (Tocilizumab) as the second drug with a $50 \%$ response rate. The two patients who did not respond to the combination of Treatment 2 and 7, both responded to Treatment 9 (Interferon $\alpha-2 \beta$ ). Ten $(34.5 \%)$ of the patients received Methylprednisolone (Treatment 8) as their second drug with 7 (70\%) responding to treatment. Of the three remaining, one received Tocilizumab (Treatment 7), one Interferon $\alpha-2 \beta$ (Treatment 9), and one Convalescent Plasma (Treatment 11). All three responded to the addition of the third drug. Interferon $\alpha-2 \beta$ (Treatment 9) was administered as the second drug in 11 (37.9\%) of the 29 patients. Nine (81.8\%) of these patients responded to treatment with two others requiring a third drug including one who received Tocilizumab (Treatment 7) and one who received Methylprednisolone (Treatment 8). Both of these patients responded to the addition of the third drug. The final (3.4\%) patient who failed Treatment 2 received Convalescent Plasma (Treatment 11) and responded to treatment.

Of the 29 patients who failed to respond to Treatment 2 as their initial treatment, 19 (65.5\%) responded to the addition of a second drug. The remaining ten $(34.5 \%)$ patients responded to the addi- tion of a third drug. Treatment 3 (Hydroxychloroquine, Clindamycin) was the initial drug Treatment assigned to 25 (8.3\%) of the 301 patients who received no outpatient treatment prior to admission. Of these patients none were randomly assigned to receive Remdesivir (Treatment 6), or Convalescent Plasma (Treatment 11) as a second line drug. Ten (40\%) of these 25 patients were randomly assigned to receive Tocilizumab (Treatment 7) as their second drug added to Treatment 3 . Of these $8(80 \%)$ responded to treatment and two required the addition of a third drug, including one who received Treatment 8 (Methylprednisolone) and one who received Treatment 11 (Convalescent Plasma), to achieve treatment success.

Six (24\%) of the 25 were randomly assigned to receive Methylprednisolone (Treatment 8) treatment in addition to Treatment 3. All $6(100 \%)$ responded to treatment requiring no additional treatment. The nine (36\%) remaining patients received Interferon $\alpha-2 \beta$ (Treatment 9). Eight (88.9\%) responded to this as the second drug with one remaining patient requiring the addition of Methylprednisolone (Treatment 8) to achieve successful treatment. Of the 25 patient who began with Treatment 3 (Hydroxychloroquine, Clindamycin) as their initial hospital treatment, $22(88 \%)$ responded to the addition of a second drug and only $3(12 \%)$ required the inclusion of a third drug for successful treatment. The fourth treatment (HCQ, Clindamycin, Primaquine) randomly selected among those who received no outpatient treatment was given to $21(7 \%)$ people. None of the patients responded to this initial treatment. During selection of the second line drug treatment to be added to Treatment 4, none of the patients were randomly assigned to either Treatment 6 (Remdesivir) or Treatment 11 (Convalescent Plasma).

Four (19\%) patients received Tocilizumab (Treatment 7) as their second drug and all four (100\%) of these patients responded to treatment. An additional $8(38.1 \%)$ received Methylprednisolone (Treatment 8), and $9(42.8 \%)$ received Interferon $\alpha-2 \beta$ (Treatment 9) as their second drug. In all 21 (100\%) of these cases, patients responded to the addition of Methylprednisolone, Tocilizumab or Interferon $\alpha-2 \beta$. Collectively none of the patients responded to first line treatment with Treatment 4; however, they all responded to the addition of either Methylprednisolone, Tocilizumab or Interferon $\alpha-2 \beta$ after initially receiving Treatment 4 including Primaquine in addition to the Hydroxychloroquine, Clindamycin found in Treatment 3. Twenty-five (8.3\%) of the 301 patients who were admitted to Phase I after being admitted without receiving outpatient treatment were placed on Treatment 5 (Primaquine, Clindamycin); the only aminoquinoline treatment regimen that did not contain Hydroxychloroquine and the only drug which did not have an intravenous or nebulizer option for patients thereby eliminating it from evaluation and use in intubated patients. Of these 25 individuals none responded to Treatment 5 as first line therapy. However all 25 (100\%), including 9 (36\%) receiving Tocilizumab (Treatment 7), 8 (32\%) receiving Methylprednisolone (Treatment 8), and 8 (32\%) receiving Interferon $\alpha-2 \beta$ (Treatment 
9) responded to the addition of these second drug Treatments and did not require the addition of a third drug for treatment.

Of the 301 patients in this part of Phase I, 39 (13\%) were initially started on Remdesivir (Treatment 6). Of these 11 (28.2\%) responded to Remdesivir as the first line drug treatment leaving $28(71.8 \%)$ requiring a second drug to be added to Remdesivir. Of the 11 who did respond, 6 (54.5\%) were from Belgium. Of the 28 people who did not respond to Remdesivir, 7 received Tocilizumab (Treatment 7) as a second drug. Four (57.1\%) of these seven people responded, with 3 others requiring the addition of a third drug Interferon $\alpha-2 \beta$ (Treatment 9) to achieve treatment success. Six of those who failed to respond to Remdesivir received Methylprednisolone (Treatment 8) as their second drug, with
$5(83.3 \%)$ responding. Only 1 required a third drug, Interferon $\alpha-2 \beta$ (Treatment 9), for treatment success. Of the remaining 14 people who failed to respond to Remdesivir, 6 received Interferon $\alpha-2 \beta$ (Treatment 9) with an $83.3 \%$ response rate. The remaining individual received and responded to Tocilizumab (Treatment 7). The remaining 8 patients received Convalescent Plasma (Treatment 11) with $100 \%$ response. When Remdesivir (Treatment 6) had Treatment 7 (Tocilizumab) added as a second drug following Remdesivir there was no significant $(\mathrm{p}=\mathrm{NS})$ improvement in treatment effect. There was one death (2.6\%) following treatment with Remdesivir among patients who received no pre-hospital treatment. This patient died on day 4 while on ventilator as shown in Table 8.

Table 8: Ventilator and Death Outcomes at Various Study Sites.

\begin{tabular}{|c|c|c|c|c|c|c|c|c|c|c|}
\hline $\begin{array}{l}\text { Study } \\
\text { Site }\end{array}$ & $\begin{array}{c}\text { Total Intu- } \\
\text { bations (\% } \\
\text { of Total) }\end{array}$ & $\begin{array}{c}\text { Total } \\
\text { Pa- } \\
\text { tients }\end{array}$ & $\begin{array}{l}\text { Phase I In- } \\
\text { tubations }\end{array}$ & $\begin{array}{c}\text { Phase I } \\
\text { Pa- } \\
\text { tients }\end{array}$ & $\begin{array}{l}\% \text { Phase } \\
\text { I Patients } \\
\text { Intubat- } \\
\text { ed }\end{array}$ & $\begin{array}{l}\text { Phase II } \\
\text { Intuba- } \\
\text { tions }\end{array}$ & $\begin{array}{l}\text { Phase II } \\
\text { Patients }\end{array}$ & $\begin{array}{l}\text { \% Phase } \\
\text { II Patients } \\
\text { Intubated }\end{array}$ & $\begin{array}{l}\text { Total Extuba- } \\
\text { tions } \\
\text { (\% of Intubated) }\end{array}$ & $\begin{array}{c}\text { Failure to Extubate } \\
\text { - Death. } \\
\text { Number-Treat- } \\
\text { ment-Day } \\
\text { (\% of Total) }\end{array}$ \\
\hline 1 & $6(85.7 \%)$ & 7 & 6 & 7 & $85.70 \%$ & NA & NA & NA & $6(100 \%)$ & 0 \\
\hline 2 & 8 (88.9 \%) & 9 & 8 & 9 & $88.90 \%$ & NA & NA & NA & $8(100 \%)$ & 0 \\
\hline \multirow{4}{*}{3} & \multirow{4}{*}{$\begin{array}{c}20(44.4 \\
\%)\end{array}$} & \multirow{4}{*}{45} & \multirow{4}{*}{17} & \multirow{4}{*}{18} & \multirow{4}{*}{$94.40 \%$} & \multirow{4}{*}{3} & \multirow{4}{*}{27} & \multirow{4}{*}{$11.10 \%$} & $\begin{array}{c}\text { Phase I: } 17 \text { (100 } \\
\%)\end{array}$ & 0 \\
\hline & & & & & & & & & \multirow{3}{*}{$\begin{array}{c}\text { Phase II: } 2 \text { (66.7 } \\
\%)\end{array}$} & $1 \mathrm{Tx} 7,9,11$ (Day 5) \\
\hline & & & & & & & & & & 1 of $20(5 \%)$ \\
\hline & & & & & & & & & & $\begin{array}{c}1 \text { of } 45 \text { patients total } \\
(2.2 \%)\end{array}$ \\
\hline 4 & $0(0 \%)$ & 3 & 0 & 3 & $0 \%$ & NA & NA & NA & NA & NA \\
\hline 5 & 2 & 6 & 2 & 6 & $33.30 \%$ & NA & NA & NA & $2(100 \%)$ & 0 \\
\hline 6 & $0(0 \%)$ & 14 & 0 & 14 & $0 \%$ & NA & NA & NA & NA & NA \\
\hline 7 & $0(0 \%)$ & 9 & 0 & 9 & $0 \%$ & NA & NA & NA & NA & NA \\
\hline \multirow{2}{*}{8} & \multirow{2}{*}{2} & \multirow{2}{*}{2} & \multirow{2}{*}{2} & \multirow{2}{*}{2} & \multirow{2}{*}{$100 \%$} & \multirow{2}{*}{ NA } & \multirow{2}{*}{ NA } & \multirow{2}{*}{ NA } & \multirow{2}{*}{$\begin{array}{c}\text { Phase I: } 0 \text { of } 2 \\
(0 \%)\end{array}$} & 1 Tx 6 (Day 4) \\
\hline & & & & & & & & & & 1 Tx 7 (Day 3) \\
\hline 9 & $0(0 \%)$ & 11 & 0 & 11 & $0 \%$ & NA & NA & NA & NA & NA \\
\hline 10 & $1(4.5 \%)$ & 22 & 1 & 22 & $4.50 \%$ & NA & NA & NA & $1(100 \%)$ & 0 \\
\hline 11 & $0(0 \%)$ & 24 & 0 & 24 & $0 \%$ & NA & NA & NA & NA & NA \\
\hline 12 & $2(7.1 \%)$ & 28 & 2 & 28 & $7.10 \%$ & NA & NA & NA & $2(100 \%)$ & 0 \\
\hline 13 & $0(0 \%)$ & 39 & 0 & 39 & $0 \%$ & NA & NA & NA & NA & NA \\
\hline 14 & $0(0 \%)$ & 49 & 0 & 49 & $0 \%$ & NA & NA & NA & NA & NA \\
\hline 15 & $0(0 \%)$ & 59 & 0 & 59 & $0 \%$ & NA & NA & NA & NA & NA \\
\hline 16 & $0(0 \%)$ & 10 & 0 & 10 & $0 \%$ & NA & NA & NA & NA & NA \\
\hline 17 & $0(0 \%)$ & 9 & 0 & 9 & $0 \%$ & NA & NA & NA & NA & NA \\
\hline \multirow{2}{*}{18} & \multirow{2}{*}{$\begin{array}{c}16(31.4 \\
\%)\end{array}$} & \multirow{2}{*}{51} & \multirow{2}{*}{14} & \multirow{2}{*}{21} & \multirow{2}{*}{$66.70 \%$} & \multirow{2}{*}{2} & \multirow{2}{*}{30} & \multirow{2}{*}{$6.70 \%$} & $\begin{array}{c}\text { Phase I: } 14(100 \\
\%)\end{array}$ & 0 \\
\hline & & & & & & & & & $\begin{array}{c}\text { Phase II: } 2(100 \\
\%)\end{array}$ & 0 \\
\hline 19 & $0(0 \%)$ & 16 & NA & NA & NA & 0 & 16 & $0 \%$ & NA & NA \\
\hline 20 & $0(0 \%)$ & 25 & NA & NA & NA & 0 & 25 & $0 \%$ & NA & NA \\
\hline
\end{tabular}




\begin{tabular}{|c|c|c|c|c|c|c|c|c|c|c|}
\hline 21 & $0(0 \%)$ & 21 & NA & NA & NA & 0 & 21 & $0 \%$ & NA & NA \\
\hline 22 & $0(0 \%)$ & 11 & NA & NA & NA & 0 & 11 & $0 \%$ & NA & NA \\
\hline 23 & $0(0 \%)$ & 31 & NA & NA & NA & 0 & 31 & $0 \%$ & NA & NA \\
\hline \multirow{2}{*}{ Total } & \multirow{2}{*}{$\begin{array}{c}57(11.4 \\
\%)\end{array}$} & \multirow{2}{*}{501} & \multirow{2}{*}{52} & \multirow{2}{*}{340} & \multirow{2}{*}{$15.30 \%$} & \multirow{2}{*}{5} & \multirow{2}{*}{161} & \multirow{2}{*}{$3.10 \%$} & \multirow{2}{*}{54 of 57 (94.7 \%) } & $\begin{array}{c}3 \text { of } 57 \text { intubations } \\
(5.3 \%)\end{array}$ \\
\hline & & & & & & & & & & $\begin{array}{c}3 \text { of } 501 \text { patients } \\
(0.6 \%)\end{array}$ \\
\hline
\end{tabular}

As shown in Table 7 when taken collectively, including patients who received aminoquinoline treatment as an outpatient and those who received no pre-hospital treatment, there were 47 people who received Remdesivir (Treatment 6) as their first in hospital treatment and of these $16(34 \%)$ responded with 1 death $(2.1$ $\%)$. Thirty individuals went on to receive a second drug with 25 $(83.3 \%)$ responding, leading to 5 individuals receiving a third drug with $100 \%$ treatment response. Treatment 7 (Tocilizumab) was provided as first line treatment to 39 (13\%) of the patients enrolled in Phase I who had received no outpatient aminoquinoline treatment. Fourteen (35.9\%) of the patients responded to Tocilizumab. One death occurred in a ventilator patient on day 3 as shown in Table 7. Of the 24 remaining patients initially started on Tocilizumab, all 24 (100\%) responded to the addition of a second drug, including 3 who received Remdesivir (Treatment 6), 2 who received Methylprednisolone (Treatment 8), 8 who received Interferon $\alpha-2 \beta$ (Treatment 9), and 11 who received Convalescent Plasma (Treatment 11).

Collectively of the patients who received no outpatient treatment, or received an aminoquinoline, almost half (49 \%) responded to Tocilizumab (Treatment 7) alone, with the remaining patients responding to the addition of either Remdesivir (Treatment 6), Methylprednisolone (Treatment 8), Interferon $\alpha-2 \beta$ (Treatment 9), or Convalescent Plasma (Treatment 11). Forty $(13.3 \%)$ of the patients in Phase I who had not received outpatient treatment received Methylprednisolone (Treatment 8) as their first drug treatment when admitted. Of these, 22 (55\%) responded to treatment. The remaining 18 (45\%) responded to second line treatment including 3 who received Remdesivir (Treatment 6), 6 who received Tocilizumab (Treatment 7), 5 that received Interferon $\alpha-2 \beta$ (Treatment 9), and 4 who received Convalescent Plasma (Treatment 11).

Including patients who received no outpatient treatment and those who received outpatient aminoquinoline treatment, 33 (64.7 $\%$ ) responded to Methylprednisolone (Treatment 8) as their first line drug. The remaining 18 (35.3\%) responded to the addition of either Tocilizumab (Treatment 7), Interferon $\alpha-2 \beta$ (Treatment 9), or Convalescent Plasma (Treatment 11). The remaining 45 (15\%) patients enrolled in Phase I were treated with Interferon $\alpha-2 \beta$ (Treatment 9). Of these 32 (71.1\%) individuals responded to Interferon $\alpha-2 \beta$ with the remaining 13 (28.9\%) responding to the addition of a second drug; including 1 given Remdesivir (Treatment 6), 5 given Tocilizumab (Treatment 7), 5 given Methylprednisolone
(Treatment 8) and 4 receiving Convalescent Plasma (Treatment 11). Combining patients who received outpatient aminoquinoline treatment with those who did not, Interferon $\alpha-2 \beta$ successfully treated patients as a single drug treatment almost three-quarters of the time; $90 \%$ of the time when patients had received outpatient aminoquinoline treatment.

\section{Phase II Outcomes - Analysis of Combined Drug Treatments Targeting the Immune ITR To Sars- Cov-2}

As shown in Figure 2, of the 501 patients treated in hospital, 161 (32.1\%) were enrolled in Phase II of the study. Of these 161 patients, 119 (73.9\%) had received outpatient aminoquinoline treatment and $42(26.1 \%)$ received no prior treatment. Figure 4 \& Table 9 shows the details of Phase II.

\section{Patients Who Failed Outpatient Aminoquinoline Treatment}

One hundred nineteen patients who had received Treatments 1 (Hydroxychloroquine, Azithromycin), 2 (Hydroxychloroquine, Doxycycline), or 3(Hydroxychloroquine, Clindamycin - No Primaquine) as outpatients and were now admitted to hospital were randomly assigned to receive one of three treatments focusing on the immune ITR associated with SARS-CoV-2. These three treatments consisted were (1) Treatment 8 (Methylprednisolone), (2) a combination treatment of Treatments 7 (Tocilizumab) and 9 (Interferon $\alpha-2 \beta$ ), or (3) a combination of Treatments 5 (Primaquine, Clindamycin - No Hydroxychloroquine), 7 (Tocilizumab) and 9 (Interferon $\alpha-2 \beta$ ). As shown in Figure $4 \&$ Table 9, 35 (29.4 \%) of these patients received Methylprednisolone (Treatment 8 ) as their first treatment with a $100 \%$ effective treatment response. Forty-three $(36.1 \%)$ patients were started on the Combination Treatment of 7 (Tocilizumab) and 9 (Interferon $\alpha-2 \beta$ ). Forty-two (97.7\%) of the patients were successfully treated. One (2.3\%) patient died on day 5 (Table 9) while on the ventilator after failing treatment and receiving additional treatment with Convalescent Plasma (Treatment 11). Forty-one (34.4\%) of the 119 were started on Combination Treatment 5 (Primaquine, Clindamycin - No Hydroxychloroquine), 7 (Tocilizumab) and 9 (Interferon $\alpha-2 \beta$ ). All 41 (100\%) patients were successfully treated. Of the 119 patients who received an aminoquinoline treatment as an outpatient and then received a treatment regimen focusing on the immune ITR response to SARS-CoV-2 immediately upon admission, 118 (99.2\%) successfully responded to treatment. One $(0.8 \%)$ died on the $5^{\text {th }}$ hospital day on the ventilator after receiving Convalescent Plasma (Treatment 11). 
Table 9: Phase II Treatment Outcomes with Focus on ITR Combination Treatments.

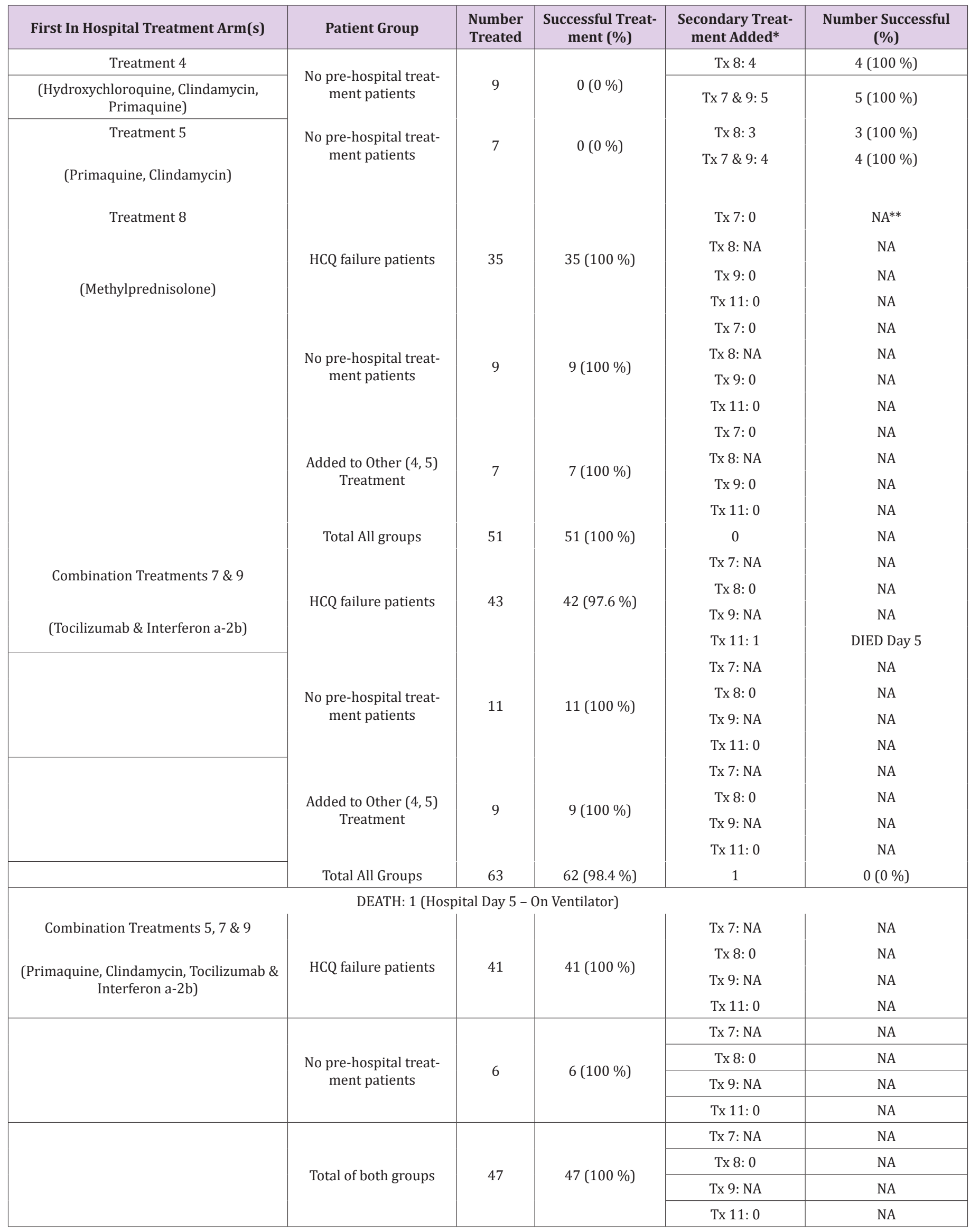

Note: *Treatment 4 - Hydroxychloroquine, Clindamycin, Primaquine; 
Treatment 5 - Primaquine, Clindamycin - No Hydroxychloroquine;

Treatment 6 - Remdesivir;

Treatment 7 - Tocilizumab;

Treatment 8 - Methylprednisolone;

Treatment 9 - Interferon $\mathrm{a}-2 \mathrm{~b}$

Treatment 11 - Convalescent Plasma;

Combination Treatments $7 \& 9$ (Tocilizumab \& Interferon a-2b); and

Combination Treatments 5, 7 \& 9 (Primaquine, Clindamycin, Tocilizumab \& Interferon a-2b)

${ }^{* *} \mathrm{NA}=$ Not Applicable

\section{Patients Who Received No Outpatient Treatment}

Phase II also included 42 patients who had not received an aminoquinoline as an outpatient as shown in Figures $2 \& 4$ and Table 9. In addition to the three treatments focusing on the immune ITR response to SARS-CoV-2, these patients were also randomized to potentially receive one of two aminoquinoline treatments as first line treatment. These two aminoquinoline treatments were Treatment 4 (Hydroxychloroquine, Clindamycin, Primaquine), and Treatment 5 (Primaquine, Clindamycin - No Hydroxychloroquine). Nine (21.4 $\%$ ) of these 42 patients received Treatment 4 (Hydroxychloroquine, Clindamycin, Primaquine) as their first treatment. None of the patients showed a successful response. Four (44.4\%) of the nine (in red) then received Treatment 8 (Methylprednisolone) and $5(55.5 \%)$ received (in red) the combination treatment of 7 (Tocilizumab) and 9 (Interferon $\alpha-2 \beta$ ). All 9 (100\%) showed successful treatment. Seven $(16.7 \%)$ of the 42 received Treatment 5 (Primaquine, Clindamycin - No Hydroxychloroquine) as first line treatment without success. Of these 7, 3 (42.8\%) had Treatment 8 (Methylprednisolone) added (in red) to the regimen and 4 (57.1 $\%$ ) had the combination of Treatments 7 (Tocilizumab) and 9 (Interferon $\alpha-2 \beta$ ) added (in red) to the regimen. In all 7 (100\%) of the cases, patients were successfully treated.

Table 10: Measured quantitative outcomes of 52 SARS-CoV-2 Treatment regimens.

\begin{tabular}{|c|c|c|c|c|c|c|}
\hline \multicolumn{7}{|c|}{ Quantitative Changes Following Collective Evaluation of 52-Treatment Combinations } \\
\hline Treatment Arm ${ }^{\# \#}$ & $\begin{array}{l}\text { Admission } \\
\text { FMTVDM }\end{array}$ & $\begin{array}{l}\text { FMTVDM at End of Treat- } \\
\text { ment } \\
\text { (level of significance**) }\end{array}$ & $\begin{array}{l}\text { Admission } \\
\text { Ferritin }\end{array}$ & $\begin{array}{l}\text { Ferritin at End of Treatment } \\
\text { (level of significance**) }\end{array}$ & $\begin{array}{l}\text { Admission } \\
\text { IL-6 }\end{array}$ & $\begin{array}{l}\text { IL- } 6 \text { at End of Treatment } \\
\text { (level of significance**) }\end{array}$ \\
\hline \multicolumn{7}{|c|}{ Single Drug Treatment* } \\
\hline $\begin{array}{l}\text { Treatment } 1 \\
\qquad(\mathrm{n}=38)\end{array}$ & $198 \pm 24$ & $\begin{array}{l}195 \pm 22 \\
>0.9999\end{array}$ & $657 \pm 204$ & $\begin{array}{l}655 \pm 153 \\
>0.9999\end{array}$ & $56 \pm 16$ & $\begin{array}{r}49 \pm 15 \\
>0.9999\end{array}$ \\
\hline $\begin{array}{l}\text { Treatment } 2 \\
\quad(n=29)\end{array}$ & $198 \pm 24$ & $\begin{array}{l}200 \pm 22 \\
>0.9999\end{array}$ & $657 \pm 204$ & $\begin{array}{l}712 \pm 126 \\
>0.9999\end{array}$ & $56 \pm 16$ & $\begin{array}{r}56 \pm 16 \\
>0.9999\end{array}$ \\
\hline $\begin{array}{l}\text { Treatment } 3 \\
(n=25)\end{array}$ & $198 \pm 24$ & $\begin{array}{l}189 \pm 18 \\
>0.9999\end{array}$ & $657 \pm 204$ & $\begin{array}{l}709 \pm 108 \\
>0.9999\end{array}$ & $56 \pm 16$ & $\begin{array}{r}51 \pm \_13 \\
>0.9999\end{array}$ \\
\hline $\begin{array}{l}\text { Treatment } 4 \\
\qquad(n=30)\end{array}$ & $198 \pm 24$ & $\begin{array}{l}196 \pm 26 \\
>0.9999\end{array}$ & $657 \pm 204$ & $\begin{array}{l}707 \pm 157 \\
>0.9999\end{array}$ & $56 \pm 16$ & $\begin{array}{r}59 \pm 13 \\
>0.9999\end{array}$ \\
\hline $\begin{array}{l}\text { Treatment } 5 \\
\quad(n=32)\end{array}$ & $198 \pm 24$ & $\begin{array}{l}195 \pm 20 \\
>0.9999\end{array}$ & $657 \pm 204$ & $\begin{array}{l}660 \pm 153 \\
>0.9999\end{array}$ & $56 \pm 16$ & $\begin{array}{r}52 \pm 15 \\
>0.9999\end{array}$ \\
\hline $\begin{array}{l}\text { Treatment } 6 \\
(n=47)\end{array}$ & $198 \pm 24$ & $\begin{array}{l}171 \pm 36 \\
<0.0001\end{array}$ & $657 \pm 204$ & $\begin{array}{l}508 \pm 190 \\
<0.0001\end{array}$ & $56 \pm 16$ & $\begin{array}{l}41 \pm 20 \\
<0.0001\end{array}$ \\
\hline $\begin{array}{l}\text { Treatment } 7 \\
(n=49)\end{array}$ & $198 \pm 24$ & $\begin{array}{l}158 \pm 34 \\
<0.0001\end{array}$ & $657 \pm 204$ & $\begin{array}{l}490 \pm 170 \\
<0.0001\end{array}$ & $56 \pm 16$ & $\begin{array}{l}29 \pm 15 \\
<0.0001\end{array}$ \\
\hline $\begin{array}{l}\text { Treatment } 8 \\
(n=95)\end{array}$ & $198 \pm 24$ & $\begin{array}{l}139 \pm 34 \\
<0.0001\end{array}$ & $657 \pm 204$ & $\begin{array}{l}349 \pm 134 \\
<0.0001\end{array}$ & $56 \pm 16$ & $\begin{array}{l}24 \pm 15 \\
<0.0001\end{array}$ \\
\hline $\begin{array}{l}\text { Treatment } 9 \\
\quad(n=55)\end{array}$ & $198 \pm 24$ & $\begin{array}{l}142 \pm 48 \\
<0.0001\end{array}$ & $657 \pm 204$ & $\begin{array}{l}354 \pm 134 \\
<0.0001\end{array}$ & $56 \pm 16$ & $\begin{array}{l}22 \pm 15 \\
<0.0001\end{array}$ \\
\hline \multicolumn{7}{|c|}{ Dual Drug Treatment* } \\
\hline $\begin{array}{l}\text { Treatment } 1,6 \\
(\mathrm{n}=4)\end{array}$ & $198 \pm 24$ & $\begin{array}{l}181 \pm 12 \\
>0.9999\end{array}$ & $657 \pm 204$ & $\begin{array}{l}580 \pm 101 \\
>0.9999\end{array}$ & $56 \pm 16$ & $\begin{array}{c}36 \pm 8 \\
>0.9999\end{array}$ \\
\hline $\begin{array}{l}\text { Treatment } 1,7 \\
(n=11)\end{array}$ & $198 \pm 24$ & $\begin{array}{l}139 \pm 32 \\
<0.0001\end{array}$ & $657 \pm 204$ & $\begin{array}{l}326 \pm 139 \\
<0.0001\end{array}$ & $56 \pm 16$ & $\begin{array}{l}25 \pm 19 \\
<0.0001\end{array}$ \\
\hline
\end{tabular}




\begin{tabular}{|c|c|c|c|c|c|c|}
\hline $\begin{array}{l}\text { Treatment } 1,8 \\
\quad(n=10)\end{array}$ & $198 \pm 24$ & $\begin{array}{l}141 \pm 33 \\
<0.0001\end{array}$ & $657 \pm 204$ & $\begin{array}{c}356 \pm 101 \\
<0.0001\end{array}$ & $56 \pm 16$ & $\begin{array}{l}28 \pm 15 \\
<0.0001\end{array}$ \\
\hline $\begin{array}{l}\text { Treatment } 1,9 \\
\qquad(\mathrm{n}=7)\end{array}$ & $198 \pm 24$ & $\begin{array}{l}128 \pm 24 \\
<0.0001\end{array}$ & $657 \pm 204$ & $\begin{array}{c}343 \pm 217 \\
\mathrm{p}=0.0057^{* * *}\end{array}$ & $56 \pm 16$ & $\begin{array}{l}28 \pm 18 \\
<0.0001\end{array}$ \\
\hline $\begin{array}{l}\text { Treatment } 1,11 \\
(n=5)\end{array}$ & $198 \pm 24$ & $\begin{array}{l}111 \pm 16 \\
<0.0001\end{array}$ & $657 \pm 204$ & $\begin{array}{c}345 \pm 55 \\
p=0.1451\end{array}$ & $56 \pm 16$ & $\begin{array}{c}20 \pm 6 \\
\mathrm{p}=0.0023^{* * * *}\end{array}$ \\
\hline $\begin{array}{c}\text { Treatment } 2,6 \\
(n=3)\end{array}$ & $198 \pm 24$ & $\begin{array}{l}201 \pm 17 \\
>0.9999\end{array}$ & $657 \pm 204$ & $\begin{array}{l}699 \pm 116 \\
>0.9999\end{array}$ & $56 \pm 16$ & $\begin{array}{r}53 \pm 6 \\
>0.9999\end{array}$ \\
\hline $\begin{array}{l}\text { Treatment } 2,7 \\
\qquad(\mathrm{n}=4)\end{array}$ & $198 \pm 24$ & $\begin{array}{l}155 \pm 28 \\
p=0.8061\end{array}$ & $657 \pm 204$ & $\begin{array}{l}456 \pm 160 \\
>0.9999\end{array}$ & $56 \pm 16$ & $\begin{array}{c}37 \pm 21 \\
>0.9999\end{array}$ \\
\hline $\begin{array}{l}\text { Treatment 2,8 } \\
\qquad(\mathrm{n}=10)\end{array}$ & $198 \pm 24$ & $\begin{array}{l}142 \pm 50 \\
<0.0001\end{array}$ & $657 \pm 204$ & $\begin{array}{l}408 \pm 224 \\
p=0.0204\end{array}$ & $56 \pm 16$ & $\begin{array}{l}26 \pm 22 \\
<0.0001\end{array}$ \\
\hline $\begin{array}{l}\text { Treatment } 2,9 \\
\qquad(\mathrm{n}=11)\end{array}$ & $198 \pm 24$ & $\begin{array}{l}129 \pm 35 \\
<0.0001\end{array}$ & $657 \pm 204$ & $\begin{array}{c}342 \pm 158 \\
<0.0001\end{array}$ & $56 \pm 16$ & $\begin{array}{l}22 \pm 25 \\
<0.0001\end{array}$ \\
\hline $\begin{array}{l}\text { Treatment 2,11 } \\
\qquad(\mathrm{n}=1)\end{array}$ & $198 \pm 24$ & $\begin{array}{c}127 \\
p=0.9976\end{array}$ & $657 \pm 204$ & $\begin{aligned} 300 \\
p=0.9999\end{aligned}$ & $56 \pm 16$ & $\begin{array}{c}17 \\
p=0.9999\end{array}$ \\
\hline $\begin{array}{l}\text { Treatment } 3,7 \\
(n=10)\end{array}$ & $198 \pm 24$ & $\begin{array}{l}129 \pm 30 \\
<0.0001\end{array}$ & $657 \pm 204$ & $\begin{array}{l}353 \pm 151 \\
p=0.0001\end{array}$ & $56 \pm 16$ & $\begin{array}{l}21 \pm 13 \\
<0.0001\end{array}$ \\
\hline $\begin{array}{l}\text { Treatment 3,8 } \\
\qquad(\mathrm{n}=6)\end{array}$ & $198 \pm 24$ & $\begin{array}{l}102 \pm 10 \\
<0.0001\end{array}$ & $657 \pm 204$ & $\begin{array}{l}197 \pm 53 \\
<0.0001\end{array}$ & $56 \pm 16$ & $\begin{array}{r}13 \pm 4 \\
<0.0001\end{array}$ \\
\hline $\begin{array}{l}\text { Treatment } 3,9 \\
(n=9)\end{array}$ & $198 \pm 24$ & $\begin{array}{l}127 \pm 24 \\
<0.0001\end{array}$ & $657 \pm 204$ & $\begin{array}{l}367 \pm 139 \\
p=0.0020\end{array}$ & $56 \pm 16$ & $\begin{array}{l}22 \pm 12 \\
<0.0001\end{array}$ \\
\hline $\begin{array}{l}\text { Treatment } 4,7 \\
\qquad(\mathrm{n}=4)\end{array}$ & $198 \pm 24$ & $\begin{array}{l}112 \pm 9 \\
<0.0001\end{array}$ & $657 \pm 204$ & $\begin{array}{c}296 \pm 77 \\
p=0.0841\end{array}$ & $56 \pm 16$ & $\begin{array}{c}16 \pm 7 \\
p=0.0034\end{array}$ \\
\hline $\begin{array}{l}\text { Treatment } 4,8 \\
(\mathrm{n}=12)\end{array}$ & $198 \pm 24$ & $\begin{array}{l}129 \pm 33 \\
<0.0001\end{array}$ & $657 \pm 204$ & $\begin{array}{l}347 \pm 103 \\
<0.0001\end{array}$ & $56 \pm 16$ & $\begin{array}{l}25 \pm 13 \\
<0.0001\end{array}$ \\
\hline $\begin{array}{l}\text { Treatment 4,9 } \\
\qquad(\mathrm{n}=9)\end{array}$ & $198 \pm 24$ & $\begin{array}{l}124 \pm 14 \\
<0.0001\end{array}$ & $657 \pm 204$ & $\begin{array}{l}261 \pm 51 \\
<0.0001\end{array}$ & $56 \pm 16$ & $\begin{array}{r}17 \pm 9 \\
<0.0001\end{array}$ \\
\hline $\begin{array}{l}\text { Treatment } 5,7 \\
\qquad(\mathrm{n}=9)\end{array}$ & $198 \pm 24$ & $\begin{array}{l}131 \pm 16 \\
<0.0001\end{array}$ & $657 \pm 204$ & $\begin{array}{l}266 \pm 56 \\
<0.0001\end{array}$ & $56 \pm 16$ & $\begin{aligned} & 15 \pm 7 \\
< & 0.0001\end{aligned}$ \\
\hline $\begin{array}{l}\text { Treatment 5,8 } \\
\qquad(\mathrm{n}=11)\end{array}$ & $198 \pm 24$ & $\begin{array}{l}123 \pm 18 \\
<0.0001\end{array}$ & $657 \pm 204$ & $\begin{array}{l}240 \pm 98 \\
<0.0001\end{array}$ & $56 \pm 16$ & $\begin{array}{l}16 \pm 10 \\
<0.0001\end{array}$ \\
\hline $\begin{array}{l}\text { Treatment 5,9 } \\
\qquad(\mathrm{n}=8)\end{array}$ & $198 \pm 24$ & $\begin{array}{l}119 \pm 15 \\
<0.0001\end{array}$ & $657 \pm 204$ & $\begin{array}{l}309 \pm 80 \\
<0.0001\end{array}$ & $56 \pm 16$ & $\begin{aligned} & 17 \pm 4 \\
< & 0.0001\end{aligned}$ \\
\hline $\begin{array}{c}\text { Treatment } 6,7 \\
(n=7)\end{array}$ & $198 \pm 24$ & $\begin{array}{c}150 \pm 44 \\
0.0058\end{array}$ & $657 \pm 204$ & $\begin{array}{l}459 \pm 273 \\
p=0.9488\end{array}$ & $56 \pm 16$ & $\begin{array}{c}27 \pm 22 \\
p=0.0091\end{array}$ \\
\hline $\begin{array}{c}\text { Treatment 6,8 } \\
\qquad(\mathrm{n}=6)\end{array}$ & $198 \pm 24$ & $\begin{array}{l}121 \pm 35 \\
<0.0001\end{array}$ & $657 \pm 204$ & $\begin{array}{l}284 \pm 108 \\
p=0.0005\end{array}$ & $56 \pm 16$ & $\begin{array}{c}23 \pm 21 \\
p=0.0022\end{array}$ \\
\hline $\begin{array}{l}\text { Treatment 6,9 } \\
\qquad(\mathrm{n}=7)\end{array}$ & $198 \pm 24$ & $\begin{array}{l}127 \pm 24 \\
<0.0001\end{array}$ & $657 \pm 204$ & $\begin{array}{l}364 \pm 96 \\
p=0.0260\end{array}$ & $56 \pm 16$ & $\begin{array}{c}22 \pm 8 \\
p=0.0002\end{array}$ \\
\hline $\begin{array}{l}\text { Treatment 6,11 } \\
(n=10)\end{array}$ & $198 \pm 24$ & $\begin{array}{l}122 \pm 17 \\
<0.0001\end{array}$ & $657 \pm 204$ & $\begin{array}{l}288 \pm 76 \\
<0.0001\end{array}$ & $56 \pm 16$ & $\begin{array}{l}24 \pm 12 \\
<0.0001\end{array}$ \\
\hline $\begin{array}{l}\text { Treatment 7,6 } \\
(\mathrm{n}=3)\end{array}$ & $198 \pm 24$ & $\begin{array}{l}125 \pm 18 \\
<0.0071\end{array}$ & $657 \pm 204$ & $\begin{array}{c}251 \pm 59 \\
p=0.1241\end{array}$ & $56 \pm 16$ & $\begin{array}{c}18 \pm 10 \\
p=0.1304\end{array}$ \\
\hline
\end{tabular}




\begin{tabular}{|c|c|c|c|c|c|c|}
\hline $\begin{array}{l}\text { Treatment } 7,8 \\
\quad(n=2)\end{array}$ & $198 \pm 24$ & $\begin{array}{l}142 \pm 4 \\
0.9448\end{array}$ & $657 \pm 204$ & $\begin{array}{c}268 \pm 71 \\
p=0.8597\end{array}$ & $56 \pm 16$ & $\begin{array}{c}21 \pm 6 \\
p=0.9343\end{array}$ \\
\hline $\begin{array}{l}\text { Treatment } 7,9 \\
\quad(\mathrm{n}=8)\end{array}$ & $198 \pm 24$ & $\begin{array}{l}113 \pm 10 \\
<0.0001\end{array}$ & $657 \pm 204$ & $\begin{array}{l}267 \pm 45 \\
<0.0001\end{array}$ & $56 \pm 16$ & $\begin{aligned} & 14 \pm 5 \\
&<0.0001\end{aligned}$ \\
\hline $\begin{array}{l}\text { Treatment 7,11 } \\
\quad(\mathrm{n}=11)\end{array}$ & $198 \pm 24$ & $\begin{array}{l}120 \pm 15 \\
<0.0001\end{array}$ & $657 \pm 204$ & $\begin{array}{l}299 \pm 90 \\
<0.0001\end{array}$ & $56 \pm 16$ & $\begin{array}{c}18 \pm 6 \\
<0.0001\end{array}$ \\
\hline $\begin{array}{l}\text { Treatment 8,6 } \\
\qquad(\mathrm{n}=3)\end{array}$ & $198 \pm 24$ & $\begin{array}{l}126 \pm 21 \\
0.0079\end{array}$ & $657 \pm 204$ & $\begin{array}{c}295 \pm 82 \\
p=0.4472\end{array}$ & $56 \pm 16$ & $\begin{array}{c}13 \pm 4 \\
p=0.0147\end{array}$ \\
\hline $\begin{array}{l}\text { Treatment } 8,7 \\
(\mathrm{n}=6)\end{array}$ & $198 \pm 24$ & $\begin{array}{l}132 \pm 16 \\
<0.0001\end{array}$ & $657 \pm 204$ & $\begin{array}{l}240 \pm 132 \\
<0.0001\end{array}$ & $56 \pm 16$ & $\begin{array}{l}12 \pm 5 \\
<0.0001\end{array}$ \\
\hline $\begin{array}{l}\text { Treatment } 8,9 \\
(\mathrm{n}=5)\end{array}$ & $198 \pm 24$ & $\begin{array}{l}121 \pm 18 \\
<0.0001\end{array}$ & $657 \pm 204$ & $\begin{array}{l}213 \pm 23 \\
<0.0001\end{array}$ & $56 \pm 16$ & $\begin{aligned} & 8 \pm 2 \\
< & 0.0001\end{aligned}$ \\
\hline $\begin{array}{l}\text { Treatment } 8,11 \\
(\mathrm{n}=4)\end{array}$ & $198 \pm 24$ & $\begin{array}{l}130 \pm 17 \\
0.0009\end{array}$ & $657 \pm 204$ & $\begin{array}{c}278 \pm 49 \\
p=0.0377\end{array}$ & $56 \pm 16$ & $\begin{array}{c}14 \pm 4 \\
p=0.0007\end{array}$ \\
\hline $\begin{array}{l}\text { Treatment 9,6 } \\
\qquad(\mathrm{n}=1)\end{array}$ & $198 \pm 24$ & $\begin{array}{c}140 \\
>0.9999\end{array}$ & $657 \pm 204$ & $\begin{array}{c}318 \\
>0.9999\end{array}$ & $56 \pm 16$ & $\begin{array}{c}12 \\
p=0.9963\end{array}$ \\
\hline $\begin{array}{l}\text { Treatment 9,7 } \\
\quad(n=5)\end{array}$ & $198 \pm 24$ & $\begin{array}{l}122 \pm 15 \\
<0.0001\end{array}$ & $657 \pm 204$ & $\begin{array}{c}252 \pm 44 \\
p=0.0006\end{array}$ & $56 \pm 16$ & $\begin{array}{c}14 \pm 8 \\
<0.0001\end{array}$ \\
\hline $\begin{array}{l}\text { Treatment } 9,8 \\
(\mathrm{n}=4)\end{array}$ & $198 \pm 24$ & $\begin{array}{c}150 \pm 23 \\
0.4400\end{array}$ & $657 \pm 204$ & $\begin{array}{c}259 \pm 79 \\
p=0.0144\end{array}$ & $56 \pm 16$ & $\begin{array}{c}22 \pm 18 \\
p=0.0929\end{array}$ \\
\hline $\begin{array}{l}\text { Treatment } 9,11 \\
(n=4)\end{array}$ & $198 \pm 24$ & $\begin{array}{l}124 \pm 15 \\
<0.0001\end{array}$ & $657 \pm 204$ & $\begin{array}{c}234 \pm 52 \\
p=0.0035\end{array}$ & $56 \pm 16$ & $\begin{array}{l}12 \pm 6 \\
<0.0001\end{array}$ \\
\hline \multicolumn{7}{|c|}{ Triple Drug Treatment* } \\
\hline $\begin{array}{l}\text { Treatment } 1 \text { plus } \\
\text { two of the fol- } \\
\text { lowing }(6-9,11) \\
(n=11)\end{array}$ & $198 \pm 24$ & $\begin{array}{l}118 \pm 15 \\
<0.0001\end{array}$ & $657 \pm 204$ & $\begin{array}{l}279 \pm 63 \\
<0.0001\end{array}$ & $56 \pm 16$ & $\begin{array}{l}19 \pm 6 \\
<0.0001\end{array}$ \\
\hline $\begin{array}{l}\text { Treatment } 2 \text { plus } \\
\text { two of the fol- } \\
\text { lowing }(7-9,11) \\
(\mathrm{n}=10)\end{array}$ & $198 \pm 24$ & $\begin{array}{l}121 \pm 15 \\
p<0.0001\end{array}$ & $657 \pm 204$ & $\begin{array}{c}286 \pm 72 \\
p<0.0001\end{array}$ & $56 \pm 16$ & $\begin{array}{c}17 \pm 7 \\
p<0.0001\end{array}$ \\
\hline $\begin{array}{l}\text { Treatment } 3 \text { plus } \\
\text { two of the fol- } \\
\text { lowing }(7-9,11) \\
(\mathrm{n}=3)\end{array}$ & $198 \pm 24$ & $\begin{array}{l}110 \pm 26 \\
<0.0001\end{array}$ & $657 \pm 204$ & $\begin{array}{l}296 \pm 110 \\
p=0.4505\end{array}$ & $56 \pm 16$ & $\begin{array}{c}17 \pm 10 \\
p=0.1011\end{array}$ \\
\hline $\begin{array}{l}\text { Treatment } 6 \text { plus } \\
\text { two of the follow- } \\
\text { ing }(7-9)(n=5)\end{array}$ & $198 \pm 24$ & $\begin{array}{l}128 \pm 13 \\
<0.0001\end{array}$ & $657 \pm 204$ & $\begin{array}{c}300 \pm 73 \\
p=0.0135\end{array}$ & $56 \pm 16$ & $\begin{array}{c}18 \pm 7 \\
p=0.0004\end{array}$ \\
\hline \multicolumn{7}{|c|}{ Phase II Combination Drug Treatment (Initial Single Drug Treatment from Phase II Included Above)* } \\
\hline $\begin{array}{c}\text { Treatment 4, } \\
(7,9)(n=5)\end{array}$ & $198 \pm 24$ & $\begin{array}{l}110 \pm 11 \\
<0.0001\end{array}$ & $657 \pm 204$ & $\begin{array}{c}298 \pm 71 \\
p=0.0121\end{array}$ & $56 \pm 16$ & $\begin{array}{c}22 \pm 8 \\
p=0.0091\end{array}$ \\
\hline $\begin{array}{c}\text { Treatment 5, } \\
(7,9)(n=4)\end{array}$ & $198 \pm 24$ & $\begin{array}{l}121 \pm 16 \\
<0.0001\end{array}$ & $657 \pm 204$ & $\begin{array}{c}434 \pm 63 \\
p=0.9993\end{array}$ & $56 \pm 16$ & $\begin{array}{c}34 \pm 20 \\
p=0.9962\end{array}$ \\
\hline $\begin{array}{l}\text { Treatment }(7,9) \\
\quad(n=46)\end{array}$ & $198 \pm 24$ & $\begin{array}{l}132 \pm 29 \\
<0.0001\end{array}$ & $657 \pm 204$ & $\begin{array}{l}295 \pm 151 \\
<0.0001\end{array}$ & $56 \pm 16$ & $\begin{array}{l}16 \pm 11 \\
<0.0001\end{array}$ \\
\hline $\begin{array}{l}\text { Treatment }(5,7,9) \\
\qquad(\mathrm{n}=56)\end{array}$ & $198 \pm 24$ & $\begin{array}{l}124 \pm 19 \\
<0.0001\end{array}$ & $657 \pm 204$ & $\begin{array}{l}275 \pm 65 \\
<0.0001\end{array}$ & $56 \pm 16$ & $\begin{aligned} & 14 \pm 7 \\
< & 0.0001\end{aligned}$ \\
\hline
\end{tabular}

Note: \#Treatment designations include the sequence by which treatment drugs were added; e.g. Treatment 1,6 means the first treatment was Treatment 1 followed by the addition of Treatment 6 ; Treatment $4,(7,9)$ means the first Treatment was Treatment 4 followed by the addition of combination Treatments 7 and 9. 
*All values are Mean \pm Standard Deviation.

**All levels of statistical significance are displayed as "p-values" with statistical significance designated as a p-value of $\leq 0.05$.

***Shows delayed change in Ferritin compared with FMTVDM.

**** Shows delayed change in IL-6 compared with FMTVDM although less delayed than Ferritin.

Nine $(21.4 \%)$ of the 42 patients who received no treatment as outpatients, received Treatment 8 (Methylprednisolone) as their first line in hospital drug treatment. All 9 (100\%) responded to treatment. In total there were 51 patients who received Treatment 8 (Methylprednisolone) during Phase II. Of these 35 had failed outpatient aminoquinoline treatment, 9 had received no outpatient treatment, and 7 others had received either Treatment 4 (Hydroxychloroquine, Clindamycin, Primaquine) or 5 (Primaquine, Clindamycin - No Hydroxychloroquine) before receiving Methylprednisolone as a second drug. In all 51 (100 $\%$ ) cases patients were successfully treated with the addition of Methylprednisolone (Treatment 8). Of the 42 patients who received no outpatient treatment, 11 (26.2\%) received 7 (Tocilizumab) and 9 (Interferon a-2b) as their first line treatment. All 11 (100\%) of these patients responded to treatment. In total 63 patients were treated with a combination of Treatments 7 (Tocilizumab) and 9 (Interferon $\alpha-2 \beta$ ) during Phase II. Of these, 62 (98.4 \%) responded to treatment, with 1 (1.6\%) failing to successfully respond. This patient died as previously noted on Day 5 while on ventilator and after receiving Convalescent Plasma (Table 8). The final 6 (14.3\%) patients received the ITR treatment combination, Treatments 5 (Primaquine, Clindamycin), 7 (Tocilizumab) \& 9 (Interferon $\alpha-2 \beta$ ) with all $6(100 \%)$ patients responding. When added to the 41 patients who also received this treatment combination, 47 patients were successfully treated with the combination of Treatments 5 (Primaquine, Clindamycin), 7 (Tocilizumab) \& 9 (Interferon $\alpha-2 \beta$ ).

Collectively Looking at Phase I And II to Evaluate The Statistical Significance of The 52-Treatment Regimens.

The cumulative 52 Treatment regimens resulting from the 10 individual Treatments applied in Phases I and II provided the measureable outcomes of the various drug treatments and treatment combinations that were then statistically compared as shown in Table 10. Following the protocol established for determining when a treatment should be abandoned due to worsening of the patient as defined by an increase in FMTVDM of greater than 25 units, no treatments were abandoned. While some treatments provided no definable measureable benefit, their absence of detriment was defined as a possible stabilization of the patient to which additional treatment was then added per protocol.

\section{Comparing the 52-Treatment Combinations to Find Sars- Cov-2 Treatment(S)}

The results of the sequential addition of treatment to prior treatment(s) resulted in 52-treatment combinations from the 10
Treatment Arms that were then statistically analyzed to determine treatment outcomes. Given an absence of statistical differences $(p=N S)$ several treatments were combined for further statistical analysis as "Triple Drug Treatment." These combinations included

a) Treatment 1 (Hydroxychloroquine, Azithromycin) to which two of the following Treatments 6-9 and 11 were added sequentially,

b) Treatment 2 (Hydroxychloroquine, Doxycycline) to which two of the following Treatments 7-9, 11 were added sequentially,

c) Treatment 3 (Hydroxychloroquine, Clindamycin - No Primaquine) to which two of the following Treatments 7-9, 11 were added sequentially, and finally

d) Treatment 4 (Hydroxychloroquine, Clindamycin, Primaquine) to which two of the following Treatments 7-9 were added sequentially. When multiple ANOVA was applied to FMTVDM, Ferritin and IL-6, the absolute and measured changes in response to treatments were statistically significant at $\mathrm{p}<0.0001$.

As shown in Table 10, when Treatment 1 (Hydroxychloroquine, Azithromycin) was given to patients there was no statistical demonstrable improvement with $\mathrm{p}>0.9999$. When Treatment 6 (Remdesivir) was added, there was no change ( $p$ > 0.9999); however, when Treatments 7 (Tocilizumab), 8 (Methylprednisolone), 9 (Interferon $\alpha-2 \beta$ ) or 11 (Convalescent Plasma) were added to Treatment 1, the improvement in FMTVDM was statistically significant at $\mathrm{p}<0.0001$. The same improvement $(\mathrm{p}<0.0001)$ was noted when two or more Treatments $(6-9,11)$ were added to Treatment 1 . Patients who received Treatment 2 (Hydroxychloroquine, Doxycycline) either alone or with the addition of Treatment 6 (Remdesivir) noted no FMTVDM improvement with $p>0.9999$. When patients receiving Treatment 2 were additionally given Treatment 7 (Tocilizumab) there was minimal change with $p$ $=0.8061$, although they did statistically improve $(\mathrm{p}<0.0001)$ when Treatment 8 (Methylprednisolone) or Treatment 9 (Interferon $\alpha-2 \beta$ ) was added. However, when Treatment 11 (Convalescent Plasma - P) was added to Treatment 2, there was no improvement ( $p=0.9976)$. Finally when Triple Drug Treatment was used with Treatment 2 , the outcome was significant $(\mathrm{p}<0.0001)$.

The Third aminoquinoline Treatment arm 3 (Hydroxychloroquine, Clindamycin) showed no improvement ( $p>0.9999$ ) when given alone; but when given with Remdesivir, Methylprednisolone, or Interferon $\alpha-2 \beta$; there was a statistically significant improvement with $\mathrm{p}<0.0001$. A similar improvement was seen when Treatment 3 was combined with two of the following treatments; Tocilizumab, Methylprednisolone, Interferon $\alpha-2 \beta$, and Convalescent Plasma ( $p<0.0001)$. When Treatment 4 consisting of Hydroxychloroquine, Clindamycin, and Primaquine was given to patients upon admission to hospital there was no measureable tissue effect ( $p>0.9999$ ) on FMTVDM. When 
Tocilizumab, Methylprednisolone, and Interferon $\alpha-2 \beta$ were added there was a statistically significant improvement with $\mathrm{p}<0.0001$. This same level of significance $(p<0.0001)$ was seen when the drug combination of Tocilizumab, and Interferon $\alpha-2 \beta$ were added to Treatment arm 4.

The fifth and final Treatment Arm 5 including an aminoquinoline included Primaquine and Clindamycin absent the Hydroxychloroquine present in Treatment Arm 4. Like the first four Treatments including an aminoquinoline in patients who had not received an aminoquinoline as an outpatient, patients treated with Treatment 5 failed to show a significant benefit with $\mathrm{p}>0.9999$. The addition of Tocilizumab, Methylprednisolone, and Interferon $\alpha-2 \beta$ resulted in a statistically significant $(p<0.0001)$ benefit. The same improvement $(\mathrm{p}<0.0001)$ was seen when the combination of Tocilizumab, and Interferon $\alpha-2 \beta$ were added to Treatment 5 . When Remdesivir (Treatment 6) was given to patients there was a significant improvement when given by itself $(p<0.0001)$; however when combined with Treatment 7 (Tocilizumab) there was less but still significant benefit noted with $p=0.0058$. This treatment benefit was not lost when Methylprednisolone, Interferon $\alpha-2 \beta$ or Convalescent Plasma were added to Remdesivir Treatment ( $p<0.0001)$. The same improvements $(\mathrm{p}<0.0001)$ were noted when Remdesivir was used in conjunction with a combination of two or more of the following three treatments, viz. Tocilizumab, Methylprednisolone and Interferon $\alpha-2 \beta$.

When patients were initially treated with Treatment 7 (Tocilizumab) there was a significant improvement with a $\mathrm{p}$ value of $<0.0001$; however when Remdesivir (Treatment 6) was added to Tocilizumab the improvement was blunted $(<0.0071)$ compared with adding either Treatment 9 (Interferon $\alpha-2 \beta$ ) or Treatment 11 (Convalescent Plasma); both of which produced a better treatment outcome ( $p<0.0001)$. However, when Methylprednisolone (Treatment 8) was added to Tocilizumab, the combination failed to show any improvement; $\mathrm{p}=0.9448$. The initiation of Methylprednisolone (Treatment 8) by itself produced the most significant initial treatment response with a reduction of FMTVDM from $198 \pm 24$ to $139 \pm 34$, with a p value of $<0.0001$. Adding Treatment 7 (Tocilizumab) or Treatment 9 (Interferon $\alpha-2 \beta$ ) to Methylprednisolone produced a significant additional benefit ( $\mathrm{p}$ $<0.0001$ ). However, when Treatment 6 (Remdesivir) was added to Methylprednisolone the treatment effect was less pronounced ( $p=0.0079$ ), as was the combination of Methylprednisolone and Convalescent Plasma (Treatment 11) with an effect of $p=0.0009$.

Initiating treatment with Interferon $\alpha-2 \beta$ (Treatment 9) produced a significant improvement $(\mathrm{p}<0.0001)$; however in the one case where Interferon $\alpha-2 \beta$ was combined with Remdesivir (Treatment 6) the combination effect was not significant with $\mathrm{p}$ $=0.9999$. The combination of Methylprednisolone (Treatment 8) with Interferon $\alpha-2 \beta$ did not produce an added benefit ( $p=0.4400$ ), while the combination of Interferon $\alpha-2 \beta$ with either Tocilizumab (Treatment 7) or Convalescent Plasma (Treatment 11) did Produce an additional beneficial effect ( $\mathrm{p}<0.0001)$. When initial treatment was provided using combination drug therapy as was done during Phase II of the study, the combination of Treatment 7 (Tocilizumab) and Treatment 9 (Interferon $\alpha-2 \beta$ ) produced a greater treatment effect $(p<0.0001)$ than any single initial drug treatment with FMTVDM going from $198 \pm 24$ to $132 \pm 29$. The use of triple drug therapy using Treatments 5 (Primaquine, Clindamycin), Treatment 7 (Tocilizumab), and Treatment 9 (Interferon a-2b) produced a slightly greater treatment benefit with FMTVDM improving from $198 \pm 24$ to $124 \pm 19(\mathrm{p}<0.0001)$.

The difference between the initial treatment of SARS-CoV-2 patients using Triple Drug Treatment combining Treatments 5 (Primaquine, Clindamycin), Treatment 7 (Tocilizumab), and Treatment 9 (Interferon $\alpha-2 \beta$ ) was not statistically different from the Dual Drug Treatment of Treatment 7 (Tocilizumab) and Treatment 9 (Interferon $\alpha-2 \beta$ ) with a $\mathrm{p}$ value of 0.6654 . While Dual Treatment with Tocilizumab and Interferon $\alpha-2 \beta$ were better than Methylprednisolone, the difference was not statistically significant ( $p=0.9200)$, in contrast to Triple Drug Treatment where a statistically significant difference of $p=0.0294$ was seen. Table 10 also shows the statistical significance of changes in Ferritin levels with treatment. The changes track the treatment response measured at the tissue level although as shown in Table 4 and Figures $7 \& 8$ there was is an initial delay in Ferritin response with greater variability. This lag time is shown by the slowed statistical response denoted by blue font in Table 8 .

\section{Quantitatively Finding Sars-COV-2 Treatment Response}

The measured changes in IL- 6 over the course of treatment for the various combinations of treatments are shown in Table 8. Differences between IL-6 and FMTVDM are displayed in red. Like Ferritin, the changes in IL-6 lag behind those measured with FMTVDM although the lag is less pronounced than that of Ferritin. Each of the three (FMTVDM, Ferritin and IL-6) measured changes correlated inversely with hospitalization indicating improvement with successful treatment. Changes in Ferritin $(r=-0.544)$ and IL-6 $(\mathrm{r}=-0.602)$ levels lagged behind measured changes in FMTVDM ( $\mathrm{r}$ $=-0.633$ ) tissue response to treatment effectiveness. Figure 7 shows the relationship between IL-6 and FMTVDM tissue measurements with a correlation of 0.718 . The correlation between Ferritin and FMTVDM was 0.673. Descriptive statistics comparing the quantitative measurements used for determination of CVP severity and treatment response are shown in Table 4 \& Figure 8. Changes in FMTVDM, Ferritin and IL-6 showed statistically significant reductions (improvements with treatment) of $\mathrm{p}<0.0001$ for each of the serial quantitative measures following treatment from admission through day 10 or until the desired treatment outcomes as defined was achieved, with the following exceptions. The difference between admission and day 4 FMTVDM measurements was $\mathrm{p}=0.04(\mathrm{p}<0.05)$ while the difference between admission and day 10 was $\mathrm{p}=0.0181(\mathrm{p}<0.05)$. While serial reductions in 
FMTVDM were measureable over the course of treatment, serial reductions in IL-6 were not statistically significant $(\mathrm{p}=\mathrm{NS})$ until day 7 when $p<0.0063$. While Ferritin levels showed persistent reductions with treatment $(\mathrm{p}<0.001)$, there was greater variability in Ferritin levels than FMTVDM or IL-6 as shown in Figure 6 \& Table 6 where variability is standard deviation squared.

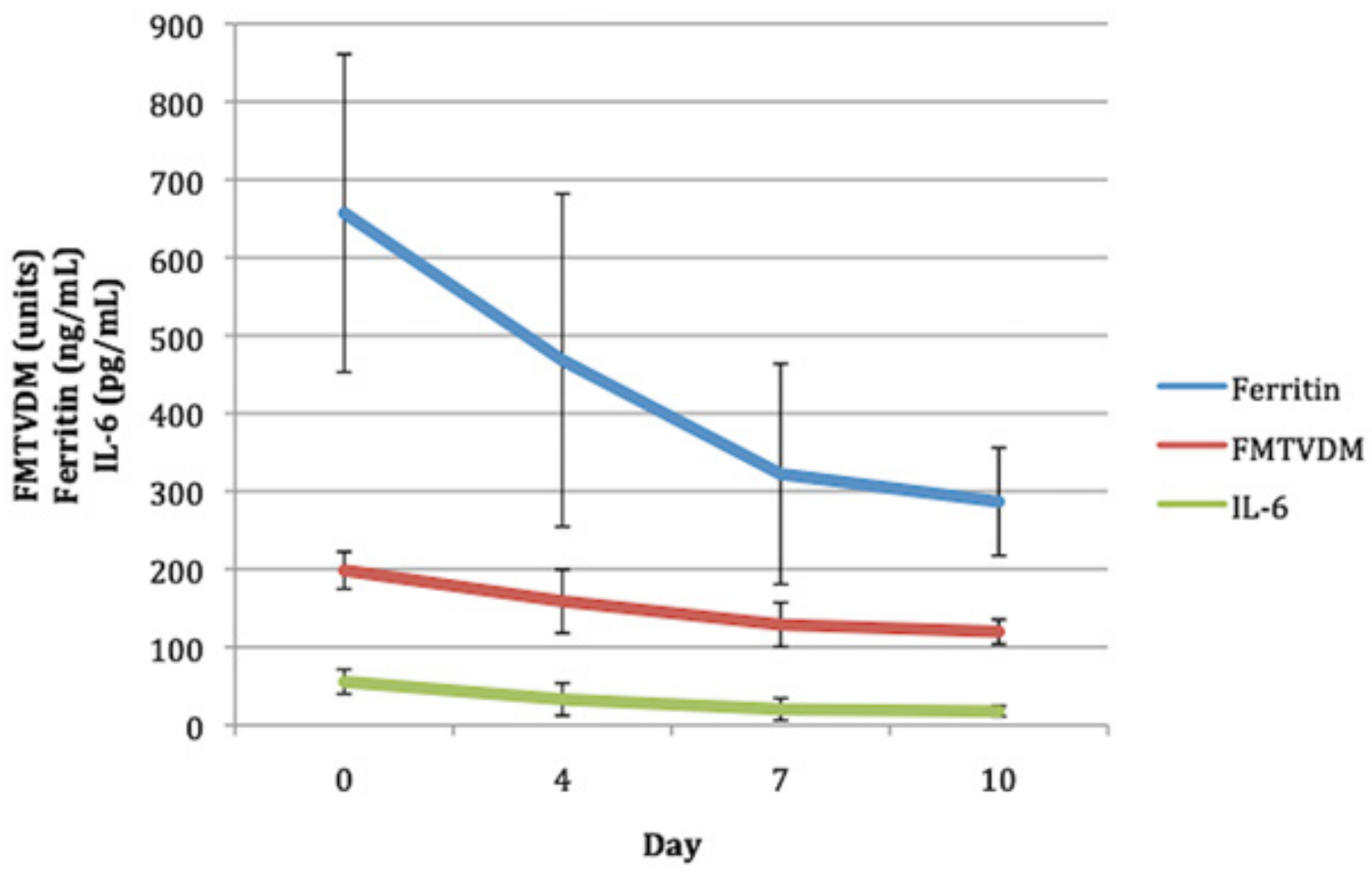

Figure 8: Measured quantitative changes in FMTVDM, Ferritin and IL-6 shown in Tables.

The graphic displays the quantified mean standard \pm deviation of FMTVDM, Ferritin and IL- 6 measurements made on the day of admission (Day 0) as well as on Days 4, 7, and 10 where changes in SARS-CoV-2 infection and ITR were measured following sequential changes in treatment. Successful treatment outcomes were defined using the quantitative measurements of FMTVDM with a reduction of $\geq 25$, or a level of $\leq 150$, Ferritin levels $<270 \mathrm{ng} / \mathrm{ml}$ for men and $<160 \mathrm{ng} / \mathrm{ml}$ for women, and an IL-6 level of $<5 \mathrm{pg} / \mathrm{ml}$. The tabulated results are shown in Tables $4 \& 10$.

\section{Differences in Discharge and Extubation By Treatment}

Following determination of the effectiveness of patient outpatient and inpatient treatments, patient outcomes were also defined by measuring the period of time patients were hospitalized for treatment and if intubated the amount of time patients remained on the ventilator. Based upon each of the patients outpatient and inpatient treatment groups Tables 8 \& 12 show the number of patients who were intubated at each site and during what Phase of the study. Beyond intubation and placement on ventilator support there were no additional differences noted in the method of oxygenation that significantly influenced outcomes, treatment response or discharge dates. As Tables 8 \& 12 show there were 52 intubations during Phase I of the study representing $15.3 \%$ (52 of 340 ) of the patients. Two (3.8\%) of these patients died during the first 5 days of admission. Only 5 patients were intubated during Phase II of the study representing $3.1 \%$ of the 161 patients enrolled in Phase II. One of these patients died on day 5. Of the 57 intubated patients, 3 (5.3\%) died - all within the first 5 days of admission. Each of the three deaths occurred on different treatments. When patient outcomes were initially analyzed to determine if there was a specific treatment - either outpatient or inpatient - that was associated with a difference in time to extubation or time to discharge, patients were evaluated looking at both outpatient and inpatient treatment regimens. As shown in Tables 10 \& 12 there were obvious differences associated with specific treatments that were statistically significant at $\mathrm{p}<0.0001$. 
Table 11: Collective comparison of four different Outpatient SARS-CoV-2 Aminoquinoline treatment protocols.

\begin{tabular}{|c|c|c|c|c|c|c|c|c|c|c|c|c|}
\hline $\begin{array}{c}\text { Study } \\
\text { Site }\end{array}$ & $\begin{array}{c}\text { Rx } 1 \\
\text { Success }\end{array}$ & $\begin{array}{l}\text { Rx } 1 \text { Fail- } \\
\text { ure } \\
\text { Entered } \\
\text { Phase I }\end{array}$ & $\begin{array}{c}\text { Rx } 1 \\
\text { Failure } \\
\text { Entered } \\
\text { Phase II }\end{array}$ & $\begin{array}{c}\text { Rx } 2 \\
\text { Success }\end{array}$ & $\begin{array}{c}\text { Rx } 2 \\
\text { Failure } \\
\text { Entered } \\
\text { Phase I }\end{array}$ & $\begin{array}{c}\text { Rx } 2 \\
\text { Failure } \\
\text { Entered } \\
\text { Phase II }\end{array}$ & $\begin{array}{c}\text { Rx } 3 \\
\text { Success }\end{array}$ & $\begin{array}{c}\text { Rx } 3 \\
\text { Failure } \\
\text { Entered } \\
\text { Phase I }\end{array}$ & $\begin{array}{c}\text { Rx } 3 \\
\text { Failure } \\
\text { Entered } \\
\text { Phase } \\
\text { II }\end{array}$ & $\begin{array}{c}\text { Rx } 4 \\
\text { Success }\end{array}$ & $\begin{array}{c}\text { Rx } 4 \\
\text { Failure } \\
\text { Entered } \\
\text { Phase I }\end{array}$ & $\begin{array}{c}\text { Rx } 4 \\
\text { Failure } \\
\text { Entered } \\
\text { Phase II }\end{array}$ \\
\hline 1 & 7 & 0 & 0 & 8 & 0 & 0 & 8 & 0 & 0 & 9 & 0 & 0 \\
\hline 2 & 5 & 0 & 0 & 5 & 0 & 0 & 5 & 0 & 0 & 8 & 0 & 0 \\
\hline 3 & 9 & 11 & 12 & 11 & 7 & 15 & 11 & 0 & 0 & 8 & 0 & 0 \\
\hline 4 & 9 & 0 & 0 & 7 & 0 & 0 & 7 & 0 & 0 & 1 & 0 & 0 \\
\hline 5 & 9 & 0 & 0 & 8 & 0 & 0 & 9 & 0 & 0 & 1 & 0 & 0 \\
\hline 6 & 5 & 0 & 0 & 5 & 0 & 0 & 5 & 0 & 0 & 7 & 0 & 0 \\
\hline 7 & 9 & 0 & 0 & 10 & 0 & 0 & 11 & 0 & 0 & 0 & 0 & 0 \\
\hline 8 & 3 & 0 & 0 & 0 & 0 & 0 & 0 & 0 & 0 & 0 & 0 & 0 \\
\hline 9 & 2 & 0 & 0 & 3 & 0 & 0 & 3 & 0 & 0 & 1 & 0 & 0 \\
\hline 10 & 23 & 0 & 0 & 17 & 0 & 0 & 23 & 0 & 0 & 19 & 0 & 0 \\
\hline 11 & 5 & 0 & 0 & 4 & 0 & 0 & 6 & 0 & 0 & 7 & 0 & 0 \\
\hline 12 & 19 & 0 & 0 & 13 & 0 & 0 & 16 & 0 & 0 & 17 & 0 & 0 \\
\hline 13 & 14 & 0 & 0 & 11 & 0 & 0 & 13 & 0 & 0 & 20 & 0 & 0 \\
\hline 14 & 16 & 0 & 0 & 13 & 0 & 0 & 11 & 0 & 0 & 20 & 0 & 0 \\
\hline 15 & 4 & 0 & 0 & 4 & 0 & 0 & 4 & 0 & 0 & 6 & 0 & 0 \\
\hline 16 & 13 & 0 & 0 & 9 & 0 & 0 & 10 & 0 & 0 & 17 & 0 & 0 \\
\hline 17 & 7 & 0 & 0 & 0 & 0 & 0 & 0 & 0 & 0 & 0 & 0 & 0 \\
\hline 18 & 25 & 9 & 20 & 18 & 10 & 9 & 20 & 2 & 1 & 27 & 0 & 0 \\
\hline 19 & 16 & 0 & 6 & 9 & 0 & 10 & 10 & 0 & 0 & 16 & 0 & 0 \\
\hline 20 & 15 & 0 & 8 & 9 & 0 & 17 & 10 & 0 & 0 & 14 & 0 & 0 \\
\hline 21 & 10 & 0 & 12 & 6 & 0 & 8 & 7 & 0 & 1 & 13 & 0 & 0 \\
\hline 22 & NA & NA & NA & NA & NA & NA & NA & NA & NA & NA & NA & NA \\
\hline 23 & NA & NA & NA & NA & NA & NA & NA & NA & NA & NA & NA & NA \\
\hline Total & 225 & 20 & \multirow{2}{*}{58 (19.1\%) } & \multirow{2}{*}{$\begin{array}{c}170 \\
(69.1 \%)\end{array}$} & \multirow{2}{*}{17 (6.9\%) } & \multirow{2}{*}{$59(24 \%)$} & \multirow{2}{*}{$\begin{array}{c}189 \\
(97.9 \%)\end{array}$} & 2 & 2 & \multirow{2}{*}{$\begin{array}{c}211 \\
(100 \%)\end{array}$} & 0 & 0 \\
\hline$(\%)$ & $74.20 \%$ & $6.60 \%$ & & & & & & $1 \%$ & $1 \%$ & & $0 \%$ & $0 \%$ \\
\hline
\end{tabular}

Table 12: Discharge, extubation and deaths associated with outpatient treatment and initial inpatient treatment.

\begin{tabular}{|c|c|c|c|c|c|}
\hline $\begin{array}{l}\text { Original Outpatient } \\
\text { Treatment (number) }\end{array}$ & $\begin{array}{c}\text { Initial Inpatient Treatment (num- } \\
\text { ber) }\end{array}$ & $\begin{array}{l}\text { Range of Dis- } \\
\text { charge Days }\end{array}$ & $\begin{array}{l}\text { Average Discharge Day } \pm \\
\text { Standard Deviation }\end{array}$ & Extubation Day & Deaths \\
\hline \multicolumn{6}{|c|}{ PHASE I } \\
\hline \multicolumn{6}{|c|}{ Prior Outpatient Hydroxychloroquine } \\
\hline \multirow{4}{*}{$\begin{array}{l}\text { Treatment }\left(\mathrm{Tx}^{\#}\right) 1 \\
\text { Hydroxychloroquine, } \\
\text { Azithromycin }\end{array}$} & Tx 6 Remdesivir $(\mathrm{n}=4)$ & $13-21$ & $16 \pm 4$ & $\begin{array}{c}3 \text { Intubated } \\
4 \pm 2\end{array}$ & 0 \\
\hline & Tx 7 Tocilizumab $(n=4)$ & $11-18$ & $14 \pm 3$ & $\begin{array}{c}3 \text { Intubated } \\
3\end{array}$ & 0 \\
\hline & Tx 8 Methylprednisolone $(n=5)$ & $12-22$ & $14 \pm 4$ & $\begin{array}{c}5 \text { Intubated } \\
4 \pm 2\end{array}$ & 0 \\
\hline & Tx 9 Interferon $\mathrm{a}-2 \mathrm{~b}(\mathrm{n}=7)$ & $10-16$ & $12 \pm 2$ & $\begin{array}{c}5 \text { Intubated } \\
4 \pm 2\end{array}$ & 0 \\
\hline
\end{tabular}




\begin{tabular}{|c|c|c|c|c|c|}
\hline \multirow{4}{*}{$\begin{array}{l}\text { Hydroxychloroquine, } \\
\text { Doxcycline }\end{array}$} & Tx 6 Remdesivir $(n=3)$ & $13-15$ & $14 \pm 1$ & $\begin{array}{c}3 \text { Intubated } \\
5 \pm 2\end{array}$ & 0 \\
\hline & Tx 7 Tocilizumab $(\mathrm{n}=6)$ & $11-18$ & $14 \pm 2$ & $\begin{array}{l}5 \text { Intubated } \\
\quad 3 \pm 1\end{array}$ & 0 \\
\hline & Tx 8 Methylprednisolone $(n=5)$ & $10-18$ & $16 \pm 3$ & $\begin{array}{c}3 \text { Intubated } \\
3\end{array}$ & 0 \\
\hline & Tx 9 Interferon $\mathrm{a}-2 \mathrm{~b}(\mathrm{n}=3)$ & $9-13$ & $11 \pm 2$ & $\begin{array}{c}3 \text { Intubated } \\
4 \pm 2\end{array}$ & 0 \\
\hline \multirow{3}{*}{$\begin{array}{l}\text { Hydroxychloroquine, } \\
\text { Clindamycin }\end{array}$} & Tx 6 Remdesivir (n=1) & 12 & 12 & $\begin{array}{c}1 \text { Intubated } \\
3\end{array}$ & 0 \\
\hline & Tx 8 Methylprednisolone $(n=1)$ & 10 & 10 & $N A^{*}$ & 0 \\
\hline & $\begin{array}{c}\text { Combined Outpatient Treatments } \\
\qquad 1-3^{* *} \\
\text { Options } 6,7,8,9(n=39)\end{array}$ & $9-22$ & $14 \pm 3$ & $\begin{array}{c}31 \text { Intubated } \\
4 \pm 2\end{array}$ & $\mathbf{0}$ \\
\hline \multicolumn{6}{|c|}{ No Prior Outpatient Hydroxychloroquine } \\
\hline \multirow{13}{*}{ NONE } & $\begin{array}{l}\text { Tx } 1 \text { Hydroxychloroquine, Azithromy- } \\
\qquad \operatorname{cin}(\mathrm{n}=38)\end{array}$ & $30-44$ & $38 \pm 4$ & $\begin{array}{l}4 \text { Intubated } \\
\qquad 8 \pm 2\end{array}$ & 0 \\
\hline & $\begin{array}{l}\text { Tx } 2 \text { Hydroxychloroquine, Doxcycline } \\
\qquad(\mathrm{n}=29)\end{array}$ & $30-44$ & $37 \pm 5$ & $\begin{array}{c}2 \text { Intubated } \\
9\end{array}$ & 0 \\
\hline & $\begin{array}{l}\text { Tx } 3 \text { Hydroxychloroquine, Clindamycin } \\
\qquad(\mathrm{n}=25)\end{array}$ & $32-44$ & $40 \pm 3$ & $\begin{array}{l}2 \text { Intubated } \\
\quad 9 \pm 4\end{array}$ & 0 \\
\hline & $\begin{array}{l}\text { Combined*** No Outpatient Hy- } \\
\text { droxychloroquine - First Inpatient } \\
\text { Treatment 1-3 }(\mathrm{n}=92)\end{array}$ & $30-44$ & $38 \pm 4$ & $\begin{array}{l}8 \text { Intubated } \\
\quad 9 \pm 2\end{array}$ & \\
\hline & $\begin{array}{l}\text { Tx } 4 \text { Hydroxychloroquine, Clindamy- } \\
\text { cin, Primaquine }(\mathrm{n}=21)\end{array}$ & $20-35$ & $27 \pm 6$ & $\begin{array}{l}2 \text { Intubated } \\
\qquad 8 \pm 1\end{array}$ & 0 \\
\hline & Tx 5 Primaquine, Clindamycin $(n=25)$ & $20-35$ & $26 \pm 6$ & $\begin{array}{l}0 \text { Intubated } \\
\text { NA }\end{array}$ & 0 \\
\hline & $\begin{array}{l}\text { Combined*** No Outpatient Hy- } \\
\text { droxychloroquine - First Inpatient } \\
\text { Treatment } 4 \text { or } 5 \text { with Primaquine. } \\
\qquad(\mathrm{n}=46)\end{array}$ & $20-35$ & $27 \pm 6$ & $\begin{array}{l}2 \text { Intubated } \\
\qquad 8 \pm 1\end{array}$ & $\mathbf{0}$ \\
\hline & Tx 6 Remdesivir $(n=39)$ & $21-25$ & $23 \pm 1$ & $\begin{array}{c}1 \text { Intubated } \\
6\end{array}$ & $\begin{array}{l}1 \text { Death } \\
\text { on Day } 4\end{array}$ \\
\hline & $\begin{array}{l}\text { Combined }{ }^{* * *} \text { No Outpatient Treat- } \\
\text { ment with Remdesivir given first. } \\
\qquad(\mathrm{n}=39)\end{array}$ & $21-25$ & $23 \pm 1$ & 1 Intubated & $\begin{array}{l}1 \text { Death } \\
\text { on Day } 4\end{array}$ \\
\hline & Tx 7 Tocilizumab (n=39) & $18-25$ & $23 \pm 2$ & $\begin{array}{c}3 \text { Intubated } \\
5 \pm 2\end{array}$ & $\begin{array}{l}1 \text { Death } \\
\text { on Day } 3\end{array}$ \\
\hline & Tx 8 Methylprednisolone $(n=40)$ & $18-25$ & $22 \pm 3$ & $\begin{array}{c}1 \text { Intubated } \\
6\end{array}$ & 0 \\
\hline & Tx 9 Interferon $\mathrm{a}-2 \mathrm{~b}(\mathrm{n}=45)$ & $18-25$ & $21 \pm 3$ & $\begin{array}{c}3 \text { Intubated } \\
6\end{array}$ & 0 \\
\hline & $\begin{array}{l}\text { Combined }{ }^{* * *} \text { No Outpatient Hy- } \\
\text { droxychloroquine - First Inpatient } \\
\text { Treatment } 7,8 \text {, or } 9 .(n=124)\end{array}$ & $18-25$ & $22 \pm 3$ & $\begin{array}{c}7 \text { Intubated } \\
6 \pm 1\end{array}$ & $\begin{array}{l}1 \text { Death } \\
\text { on Day } 3\end{array}$ \\
\hline
\end{tabular}




\begin{tabular}{|c|c|c|c|c|c|}
\hline \multicolumn{6}{|c|}{ Prior Outpatient Hydroxychloroquine } \\
\hline \multirow{4}{*}{$\begin{array}{l}\text { Hydroxychloroquine, } \\
\text { Azithromycin }\end{array}$} & Tx 8 Methylprednisolone $(\mathrm{n}=17)$ & $7-9$ & $7 \pm 1$ & $\begin{array}{l}0 \text { Intubated } \\
\text { NA }\end{array}$ & 0 \\
\hline & $\begin{array}{c}\text { Tx } 5 \text { \& } 7 \text { Primaquine, Clindamycin \& } \\
\text { Tocilizumab }(n=3)\end{array}$ & $7-9$ & $8 \pm 1$ & $\begin{array}{l}0 \text { Intubated } \\
\text { NA }\end{array}$ & 0 \\
\hline & $\begin{array}{l}\text { Tx 5, } 7 \text { \& } 9 \text { Primaquine, Clindamycin, } \\
\text { Tocilizumab \& Interferon a-2b (n=19) }\end{array}$ & $6-9$ & $7 \pm 1$ & $\begin{array}{l}0 \text { Intubated } \\
\text { NA }\end{array}$ & 0 \\
\hline & $\begin{array}{c}\text { Tx } 7 \& 9 \text { Tocilizumab \& Interferon } \\
\text { a-2b }(n=20)\end{array}$ & $6-13$ & $8 \pm 2$ & $\begin{array}{c}3 \text { Intubated } \\
4 \pm 1\end{array}$ & $\begin{array}{l}1 \text { Death } \\
\text { on Day } 5\end{array}$ \\
\hline \multirow{4}{*}{$\begin{array}{l}\text { Hydroxychloroquine, } \\
\text { Doxcycline }\end{array}$} & Tx 8 Methylprednisolone $(\mathrm{n}=18)$ & $7-10$ & $8 \pm 1$ & $\begin{array}{l}0 \text { Intubated } \\
\text { NA }\end{array}$ & 0 \\
\hline & $\begin{array}{c}\text { Tx } 5 \text { \& } 7 \text { Primaquine, Clindamycin \& } \\
\text { Tocilizumab }(n=5)\end{array}$ & $7-8$ & $7 \pm 1$ & $\begin{array}{l}0 \text { Intubated } \\
\text { NA }\end{array}$ & 0 \\
\hline & $\begin{array}{l}\text { Tx 5, } 7 \text { \& } 9 \text { Primaquine, Clindamycin, } \\
\text { Tocilizumab \& Interferon a-2b }(n=22)\end{array}$ & $7-12$ & $8 \pm 1$ & $\begin{array}{c}1 \text { Intubated } \\
3\end{array}$ & 0 \\
\hline & $\begin{array}{c}\text { Tx } 7 \& 9 \text { Tocilizumab \& Interferon } \\
\text { a-2b }(n=13)\end{array}$ & $6-11$ & $8 \pm 1$ & $\begin{array}{c}1 \text { Intubated } \\
3\end{array}$ & 0 \\
\hline \multirow[t]{3}{*}{$\begin{array}{l}\text { Hydroxychloroquine, } \\
\text { Clindamycin }\end{array}$} & $\begin{array}{l}\text { Tx 5, } 7 \text { \& } 9 \text { Primaquine, Clindamycin, } \\
\text { Tocilizumab \& Interferon } a-2 b(n=1)\end{array}$ & 7 & 7 & $\begin{array}{l}0 \text { Intubated } \\
\text { NA }\end{array}$ & NA \\
\hline & $\begin{array}{c}\text { Tx } 7 \& 9 \text { Tocilizumab \& Interferon } \\
\text { a- } 2 \mathrm{~b}(\mathrm{n}=1)\end{array}$ & 8 & 8 & $\begin{array}{l}0 \text { Intubated } \\
\text { NA }\end{array}$ & NA \\
\hline & $\begin{array}{l}\text { Combined } \\
\text { ments } 1-3 \\
\text { Options } 8 ; 5,7 ; 5,7,9 ; 7,9 .(n=119)\end{array}$ & $6-13$ & $8 \pm 1$ & $\begin{array}{c}5 \text { Intubated } \\
\quad 3 \pm 1\end{array}$ & $\begin{array}{l}1 \text { Death } \\
\text { on Day } 5\end{array}$ \\
\hline \multicolumn{6}{|c|}{ No Prior Outpatient Hydroxychloroquine } \\
\hline \multirow{7}{*}{ NONE } & $\begin{array}{l}\text { Tx } 4 \text { Hydroxychloroquine, Clindamy- } \\
\text { cin, Primaquine }(n=9)\end{array}$ & $27-31$ & $29 \pm 1$ & $\begin{array}{c}0 \text { Intubated } \\
\text { NA }\end{array}$ & 0 \\
\hline & Tx 5 Primaquine, Clindamycin (n=7) & $27-32$ & $30 \pm 2$ & $\begin{array}{c}0 \text { Intubated } \\
\text { NA }\end{array}$ & 0 \\
\hline & $\begin{array}{l}\text { Combined*** No Outpatient Hy- } \\
\text { droxychloroquine - First Inpatient } \\
\text { Treatment with Primaquine. (n=16) }\end{array}$ & $27-32$ & $29 \pm 2$ & $\begin{array}{c}0 \text { Intubated } \\
\text { NA } \\
\end{array}$ & $\mathbf{0}$ \\
\hline & Tx 8 Methylprednisolone (n=9) & $14-19$ & $17 \pm 2$ & $\begin{array}{c}0 \text { Intubated } \\
\text { NA } \\
\end{array}$ & 0 \\
\hline & $\begin{array}{l}\text { Tx 5, } 7 \text { \& } 9 \text { Primaquine, Clindamycin, } \\
\text { Tocilizumab \& Interferon } a-2 b(n=6)\end{array}$ & $14-19$ & $18 \pm 2$ & $\begin{array}{l}0 \text { Intubated } \\
\text { NA }\end{array}$ & 0 \\
\hline & $\begin{array}{c}\text { Tx } 7 \& 9 \text { Tocilizumab \& Interferon } \\
\text { a-2b }(n=11)\end{array}$ & $13-19$ & $17 \pm 2$ & $\begin{array}{c}0 \text { Intubated } \\
\text { NA }\end{array}$ & 0 \\
\hline & $\begin{array}{l}\text { Combined }^{* * *} \text { No Outpatient Hy- } \\
\text { droxychloroquine - First Inpatient } \\
\text { Treatment } 8 ; 5,7,9 ; 7,9 .(\mathrm{n}=26)\end{array}$ & $13-19$ & $17 \pm 2$ & $\begin{array}{c}\text { O Intubated } \\
\text { NA }\end{array}$ & 0 \\
\hline
\end{tabular}

Note: \# Tx $=$ Treatment

${ }^{*}$ No patients were intubated in this group.

${ }^{* *}$ As shown in Tables 4 and 5 there were no outpatient failures noted for Treatment 4 .

${ }^{* * *}$ Group effects noted in bold print. 
The results were then clustered together based upon common factors as shown in Table 12 with a p value of $<0.0001$. The results of these clustered groups are displayed in bold font. When patients were given sequential single drug treatments, successively building upon prior treatments to find the treatment combination that worked for any given patient based upon measured changes in FMTVDM, Ferritin and IL-6; patients who had received outpatient Treatments 1, 2 or 3 - all with hydroxychloroquine - and required admission to the hospital and were then started on a single drug regimen from Treatments 6-9 had an average hospital stay of $14 \pm 3$ days (range 9 - 22 days). Of these 31 (79.5\%) were intubated and successfully extubated in $4 \pm 2$ days. In contrast, patients who had not received an aminoquinoline as an outpatient and who received single drug sequential treatments had a range of hospitalization from 18 - 44 days. Upon further examination these patients clustered based upon initial inpatient treatment. Those who were admitted and given an aminoquinoline treatment without Primaquine first (Treatments 1-3) were hospitalized for an average of $38 \pm 4$ days with a range of $30-44$ days. Of these 8 (8.7 \%) of the 92 required intubation. These patients were extubated on average within $9 \pm 2$ days. Two specialized groups of patients who had not received outpatient aminoquinoline treatment, received Treatment 4 or 5 containing Primaquine as their first line treatment. These patients were admitted for an average of $27 \pm 6$ days. Only 2 (4.3 $\%)$ of these 46 patients were intubated and they were extubated in $8 \pm 1$ days.

Patients who were given Remdesivir (Treatment 6) as their first single drug treatment and who had not received outpatient treatment with an aminoquinoline had an average hospital stay of $23 \pm 1$ days (21 - 25 days). One (2.6\%) of these patients required Intubation and died on day 4 of hospitalization. The remaining patients who were enrolled in Phase I who did not received aminoquinoline (Treatments 1-3) as an outpatient were started either on Tocilizumab (Treatment 7), Methylprednisolone (Treatment 8), or Interferon $\alpha-2 \beta$ ) (Treatment 9) as a single drug treatment. These single agent drugs focusing on treating InflammoThrombotic Responses (ITR) were associated with an average hospital stay of $22 \pm 3$ days, ranging from 18 - 25 days. Seven (5.6\%) of these 124 patients required intubation, resulting in one death on day 3 of admission. The remaining six patients were extubated on an average of $6 \pm 1$ days. When the initial hospital drug treatment consisted of using either Methylprednisolone (Treatment 8) or a combination of drugs (Treatment 7 . Tocilizumab, Treatment 9 - Interferon $\alpha-2 \beta$ ) focusing on earlier treatment the ITR, and the possible inclusion of Primaquine $[6,7]$ to further inhibit viral replication and decrease the ITR, patients who had received outpatient treatment with one of the regimens containing Hydroxychloroquine without Primaquine (Treatments 1-3), and who were initiated on these treatment regimens had an average hospital stay of $8 \pm 1$ day, ranging from $6-13$ days. Of these 119 patients, 5 (4.2\%) were intubated with one death on day 5 of the admission.
Patients who received no outpatient aminoquinoline treatment (Treatments 1-3) and who received either Treatment 4 (Hydroxychloroquine, Clindamycin, Primaquine) or 5 (Primaquine, Clindamycin) as their first line treatment in hospital had an average hospital stay of $29 \pm 2$ days, ranging from 27 - 32 day. None of these patients required intubation and there were no deaths. Finally, patients who received Methylprednisolone (Treatment 8) or a combination of drugs (Treatment 7 -Tocilizumab, Treatment 9 - Interferon $\alpha-2 \beta$ with or without Treatments 4 or 5 containing Primaquine) and had not received outpatient aminoquinoline treatment had an average hospital stay of $17 \pm 2$ days, ranging from 13 - 19 days. None of these patients required intubation and there were no deaths. The shortest hospital stay of slightly more than a week ( $8 \pm 1$ days) was seen in patients who had received hydroxychloroquine (Treatment 1-3) as an outpatient, even though it had failed to prevent admission, and then received as first line hospital treatment either Treatment 8 (Methylprednisolone), or combination Treatment 5 (Primaquine, Clindamycin) and 7 (Tocilizumab); or Treatments 5 (Primaquine, Clindamycin), 7 (Tocilizumab) and 9 (Interferon $\alpha-2 \beta$ ) or Treatments 7 (Tocilizumab) and 9 (Interferon $\alpha-2 \beta$ ) all targeting the immune ITR, and who were not intubated.

The second shortest hospital stays also occurred among patients who had received outpatient HCQ treatments and then received as their first single drug sequential treatment either Treatment 6 (Remdesivir), Treatment 7 (Tocilizumab), Treatment 8 (Methylprednisolone), or Treatment 9 (Interferon $\alpha-2 \beta$ ). This regimen resulted in an average hospital stay of 2 ( $14 \pm 3$ days) weeks. By contrast the two longest hospital stays were associated with patients who had not received outpatient HCQ treatment and either received (1) a combination of Hydroxychloroquine, Clindamycin and Primaquine (Treatment 4), or Primaquine and Clindamycin without the Hydroxychloroquine (Treatment 5), with an average hospital stay of $29 \pm 2$ days; or (2) were initially started on Treatment 1-3 containing Hydroxychloroquine. The difference between these groups with the shortest and longest stays is statistically significant at $\mathrm{p}<0.0001$. The treatment combination that resulted in the fastest recovery time and the shortest hospital stay was for patients who upon admission were immediately started on either Treatment 8 (Methylprednisolone); or combination of Treatments including (1) 5 (Primaquine, Clindamycin) \& 7 (Tocilizumab), (2) 5 (Primaquine, Clindamycin), 7 (Tocilizumab) \& 9 (Interferon $\alpha-2 \beta$ ), or (3) Treatments 7 (Tocilizumab) \& 9 (Interferon $\alpha-2 \beta$ ). As shown in Table 12 for patients who had received prior aminoquinoline treatment as an outpatient, the time for recovery and discharge from hospital was approximately one week, and slightly more than two weeks for those who had not received outpatient treatment. There was no statistically significant difference $(p=0.5216)$ between the four treatments groups targeting the immune ITR associated with SARS-CoV-2, with each resulting in successful treatment and discharge on an average of 7-8 days. 


\section{Discussion}

This study addressed several key issues important in defining the treatment of SARS-CoV-2, including the prevalence of those who did not require treatment in the outpatient setting as well as those who responded to treatment as outpatients using aminoquinoline treatments. Following failure to recover from SARS-CoV-2 - with or without outpatient treatment - patients were hospitalized for treatment. During the inpatient treatment patients were evaluated to determine what treatments or combinations of treatments provided a statistically significant treatment effect (Table 10) as well as what treatments were necessary to ultimately successful treat (FMTVDM > 25 reduction or FMTVDM <150; Ferritin levels $<270 \mathrm{ng} / \mathrm{ml}$ for men and $<160 \mathrm{ng} / \mathrm{ml}$ for women, and an IL-6 level of $<5 \mathrm{pg} / \mathrm{ml}$ ) SARS-CoV-2 (Tables 4 \& 10). The importance of these different treatment approaches on successful extubation, survival and discharge are shown in Tables 8 \& 12. Determination of the severity of CVP and successful treatment was quantitatively determined using FMTVDM, Ferritin and IL-6. FMTVDM provided a direct measurement of changes happening at the tissue level, where Ferritin and IL-6 provided indirect evidence of changes in CVP as well as elsewhere in the body [28,29]. While all three quantitative measures were statistically significant over the course of treatment only FMTVDM and Ferritin showed statistically significant sequential changes throughout the course of treatment although Ferritin results showed a greater variability and thus less reliability. IL-6 changes required 7-days to become statistically significant. As we believe this study demonstrates, successful treatment of SARS$\mathrm{CoV}-2$ requires diligent attention to addressing the ITR sooner than later and adjusting treatments based upon measured tissue and blood response.

It is important to clinically distinguish between Cytokine Release Syndrome (CRS) and InflammoThrombotic Response (ITR). At first glance the biochemical responses appear to be similar with increases in both Ferritin and Interleukin-6 levels; however CRS defines the syndrome following car T-cell treatments where the body's immune system is being attacked by human intervention treatment. In an ITR [2] as shown in Figure 1, the person's immune system is responding to an infectious process. In people with naïve immune systems or pre-existing hyper inflammatory states (comorbidities) the impaired controlled immune response results in an ITR associated with pulmonary edema and thrombi; a problem both for the lungs as well as the rest of the body. With immediate treatment focusing on the ITR including the use of subcutaneous heparin, thrombus formation and the ITR can be brought under control as evidenced by the reductions in Ferritin and IL-6 levels, and tissue improvement measured with FMTVDM quantitative nuclear imaging. Of the 1800 patients slightly more than half of those who tested positive for SARS-CoV-2 were started on outpatient aminoquinoline treatments involving Hydroxychloroquine (HCQ). While there were four different treatment regimens roughly equally applied accounting for a perceived $83.4 \%$ successful treatment response, 158 (16.6 \%) of those treated required further treatment and admission to hospital. While there were differences between the various outpatient aminoquinoline treatments, only those who received Primaquine had complete success.

An additional 847 (47\%) of the 1800 participants were given no outpatient treatment. Of these 343 (40.5\%) failed to get better and required hospitalization. Combining both those who failed outpatient treatment and those who received no treatment and required hospitalization, there were 501 (27.8\%) people who tested positive for SARS-CoV-2 and required admission for treatment - a fact that further emphasizes the need for limiting viral replication. It is important to note that these numbers speak only to patients who sought medical care and not to the general population at large who may obtain PCR testing for contact tracing or other purposes. Of the people who initially received an aminoquinoline outpatient treatment, almost $90 \%$ responded to first line treatment with Remdesivir showing the least promising results. There were no reported outpatient failures among patients receiving outpatient Treatment 4 with Primaquine. Unlike patients who received outpatient aminoquinoline treatment, patients who received no prior treatment and were admitted to hospital using the Phase I approach of sequentially adding treatments - one per each treatment adjustment at 3-day intervals - these patients required multiple additional drug treatments to achieve treatment success with the exception of patients whose first hospital drug treatment included Primaquine. In these two groups (Treatments 4 and 5) of patients $100 \%$ failed their initial treatment; but successfully responded $100 \%$ of the time when the second drug added to Treatment 4 or 5 , was Tocilizumab, Methylprednisolone or Interferon $\alpha-2 \beta$.

When Remdesivir was used as the first drug following admission, it was effective only a third of the time. It was substantially better at treating those who had received outpatient aminoquinoline treatment than those who had not. Among those who had not received prior outpatient treatment, there was one death that occurred on the fourth day of admission while the patient was on ventilator. The addition of Tocilizumab as the second drug following Remdesivir resulted in no significant improvement suggesting a drug-drug interaction. More than half of the patients who responded to Remdesivir were from Belgium raising the question of a possible genetic component. The reduction of effect between Remdesivir and Tocilizumab was only noted when Remdesivir was the first drug. In cases where Tocilizumab was given first, the addition of Remdesivir did not diminish the treatment effect. In fact, all of the patients who received Tocilizumab first and then received Remdesivir responded to treatment. Like Remdesivir, there was one death associated with the administration of Tocilizumab as the first administered treatment. This occurred in a patient on ventilator on day 3. When Tocilizumab was the first line treatment, including patients who had or had not received outpatient aminoquinoline treatment, half of the patients responded to Tocilizumab alone 
and the other half responded to the addition of either Remdesivir, Methylprednisolone, Interferon $\alpha-2 \beta$, or Convalescent Plasma.

For patients who received no outpatient treatment or who received outpatient aminoquinoline treatment, approximately two-thirds of these patients treated with Methylprednisolone first, responded to treatment. The remaining one-third responded to the addition of Tocilizumab, Interferon $\alpha-2 \beta$, or Convalescent Plasma.

Similarly, when Interferon $\alpha-2 \beta$ was used as the first line treatment, in those who received no outpatient treatment more than $70 \%$ of the patients responded with the remaining patients responding with the addition of Tocilizumab, Methylprednisolone, or Convalescent Plasma. The response rate was $90 \%$ for those who had received outpatient aminoquinoline treatment. The most successful single drug treatment $(74.5 \%)$ for patients admitted for treatment of SARS-CoV-2 when considering both those who received outpatient aminoquinoline treatment and those who received no treatment, was Interferon $\alpha-2 \beta$ However for patients who had received outpatient aminoquinoline treatment, 90\% responded to Interferon $\alpha-2 \beta$ and $100 \%$ responded to either Methylprednisolone or Tocilizumab. The results of Phase I demonstrated a significant treatment benefit and response using either Methylprednisolone, or a combination Treatment regimen of Interferon $\alpha-2 \beta$ and Tocilizumab; particularly following outpatient treatment with an aminoquinoline most notably treatment with Primaquine. These treatments demonstrated significant success indicating the need to shift to a second phase (Phase II) of the study focusing on combining ITR treatments when patients were admitted.

During Phase II of the study the focus shifted from beginning with a single drug treatment and sequentially adding agents until treatment was successful to the initiation of treatments focusing on the immunologic ITR to SARS-CoV-2. Treatment focused on three potential ITR treatments including (1) Methylprednisolone, (2) Tocilizumab and Interferon $\alpha-2 \beta$, or (3) a combination of Primaquine, Clindamycin, Tocilizumab and Interferon $\alpha-2 \beta$. For patients who had taken an aminoquinoline as an outpatient, the use of these three different ITR focused treatments was successful in $99.2 \%$ of the cases with only one (0.8\%) failure which was associated with a patient dying on a ventilator after receiving Convalescent Plasma as an additional treatment.

For patients who had not received an aminoquinoline as an outpatient, randomization of treatment included these three ITR regimens as well as the possibility of receiving one of two treatment regimens with aminoquinolines including (1) the combination of Hydroxychloroquine, Clindamycin, and Primaquine, or (2) Primaquine and Clindamycin without Hydroxychloroquine. Of the 16 people who had not received an aminoquinoline as an outpatient and then received an aminoquinoline treatment as their first in hospital treatment, none of them improved with either Treatment 4 or 5 ; however, all 16 (100\%) responded with the addition of one of the three ITR regimens: (1) Methylprednisolone, (2) Tocilizumab and Interferon $\alpha-2 \beta$, or (3) a combination of Primaquine, Clindamycin, Tocilizumab and Interferon $\alpha-2 \beta$. These findings are consistent with what was seen during Phase I, where the treatment of patients with an aminoquinoline prior to treatment with an ITR treatment yielded successful treatment 90 $\%$ of the time when Interferon $\alpha-2 \beta$ was included and $100 \%$ of the time when Tocilizumab or Methylprednisolone was included.

By quantitatively measuring the effect of each drug as it was added to each patient's treatment regimen, we were able to statistically determine not only the impact of each drug, but also the impact of multiple drug treatments to determine the drug-drug interactions and effectiveness of treating SARS-CoV-2. The results of these treatments reveal several important findings including (a) which drugs or more importantly which drug combinations work to treat SARS-CoV-2, and (b) their impact on the patient's clinical course as measured by treatment success, intubation and extubation rates, death rates, and days to discharge. Treatment failure and success was rapidly determinable within 72-hours by measuring changes in tissue infection and ITR in the lungs using FMTVDM; with IL-6 and Ferritin taking longer to demonstrate treatment success or failure. The statistical analysis of these 52 different SARS-CoV-2 treatment regimens demonstrated that those patients who had received pre-hospital aminoquinoline treatment - even though they required hospital admission for further treatment - had a faster response to treatment with fewer intubations and shorter hospital stay. Patients who had not received an aminoquinoline prior to admission and were immediately randomized to receive (1) Methylprednisolone, (2) Tocilizumab and Interferon $\alpha-2 \beta$, or (3) a combination of Primaquine, Clindamycin, Tocilizumab and Interferon $\alpha-2 \beta$, as a first line treatment showed a $100 \%$ response to treatment; although patients who had received an aminoquinoline as an outpatient showed faster response and shorter hospitalization times. For patients who had not received an aminoquinoline as an outpatient, this could easily be added to the treatment regimen by using the Primaquine, Clindamycin, Tocilizumab and Interferon $\alpha-2 \beta$ combination. Hydroxychloroquine itself offered little if any treatment effect once the patient required hospitalization - where a sufficient period of time had elapsed between onset of symptoms and viral replication. Of patients who had not received outpatient treatment, the initiation of an aminoquinoline on admission demonstrated an increased patient response to Methylprednisolone, Tocilizumab, and Interferon $\alpha-2 \beta$. Convalescent plasma was reserved as a second line treatment due to potential transfusion and clotting concerns and was deemed to be more of a tool to secure time for patient recovery. With the immediate initiation of treatment focusing on controlling the ITR using either (1) Methylprednisolone, or (2) one of the two ITR drug combinations (a) Tocilizumab \& Interferon $\alpha-2 \beta$ or (b) Primaquine, Clindamycin, Tocilizumab \& Interferon $\alpha-2 \beta$; the use of Convalescent Plasma was moot. 
The comparison of treatments also demonstrated the importance of multi-drug regimens focusing on the immune ITR to SARSCoV-2. The available choices included (1) Tocilizumab \& Interferon $\alpha-2 \beta$, (2) Primaquine, Clindamycin, Tocilizumab \& Interferon $\alpha-2 \beta$, and (3) Methylprednisolone. The least effective treatment was seen when Remdesivir was given as the first line drug working slightly more than a quarter of the time; although patients who had received hydroxychloroquine as an outpatient and then received Remdesivir as an outpatient noted a $62 \%$ response. The treatment combination obtained by adding Tocilizumab to Remdesivir, or Remdesivir to Tocilizumab proved to have little additive effect. Rapid assertive treatment addressing the ITR demonstrated a greater treatment success sooner with shorter hospital stays compared with Phase I. Patients in Phase II who received aminoquinoline treatment as an outpatient demonstrated improvement following their first round of randomized treatment focusing on the ITR response to the virus with discharge in 6 to 13 days.

Those who had not received an aminoquinoline and received one of the three treatment combinations focusing on ITR (Methylprednisolone; Primaquine, Clindamycin, Tocilizumab \& Interferon $\alpha-2 \beta$; or Tocilizumab \& Interferon $\alpha-2 \beta$ ) required longer to improve with discharge between 12 to 19 days. Those who received no outpatient treatment and were randomized to receive a aminoquinoline treatment (Hydroxychloroquine, Clindamycin, Primaquine or Primaquine, Clindamycin - without Hydroxychloroquine) did not respond to the aminoquinoline initially and took longer to respond to ITR treatment. These patients were discharged between 21 and 30 days. Given the combination of treatment success in the outpatient setting and the shorter time to recovery in Phase I and Phase II for those who had received an aminoquinoline as outpatients, particularly when multi-drug combinations were used in Phase II, and the failure of aminoquinoline treatment to substantially change the clinical inpatient course when initially started in the hospital, this would suggest that the greatest benefit for patients treated with an aminoquinoline occurs during the initial period of time (days 3-5) when viral attachment and replication are beginning. Once the patient has passed the initial viral attachment and replication threshold and the immune response has been activated - day 4 onward - treatment benefit is achieved only when treatment is focused on reducing the consequential ITR. This is best achieved with combination drug therapy including either; Tocilizumab and Interferon $\alpha-2 \beta$; or a combination of Primaquine and Clindamycin when added to Tocilizumab and Interferon $\alpha-2 \beta$.

In addition to the measured changes of FMTVDM, Ferritin and IL-6, demonstrating successful treatment of SARS-CoV-2, there are other measures frequently discussed when looking at patient success or treatment failure. These include intubation rate, extubation rate, deaths and days to discharge. Among patients admitted and treated in this study several key points standout regarding these later factors. First, the more rapidly treatment is initiated to bring the ITR under control, the more successful the patients treatment course will be and the more likely they will not be intubated and if intubated, the more rapidly they will be extubated. They will also leave the hospital statistically sooner. Secondly, the use of a multidrug treatment to address the ITR and/ or the use of substantial dosing of methylprednisolone - requiring a careful titration off the steroid - to reduce the ITR, will result in the patient responding to treatment significantly faster with earlier discharge. The patients who took one of the HCQ treatments as outpatients and were subsequently admitted for further treatment, at first appeared to have failed treatment; however, it was these individuals that had the fastest response when ITR therapies were initiated and they were discharged soonest. In contrast, patients who had not received aminoquinoline treatment as outpatients and then received an aminoquinoline as an inpatient had the slowest response times and were hospitalized the longest, suggesting that there may be some latent benefit not yet accounted for in those who received such treatment as outpatients. Indicating that once the virus has had sufficient time to invade, replicate and potentiate an ITR, particularly in those who are immune naïve or have comorbidities, that further use of an aminoquinoline has minimal if any effect. Like HIV, the best treatment for SARS-CoV-2 is a combination of drugs provided immediately upon infection during the initial development of symptoms or recognition of exposure; coupling an aminoquinoline (Hydroxychloroquine or Primaquine) as an outpatient with immediate ITR treatment using Methylprednisolone as an outpatient; or adding either Methylprednisolone, or the combination of Tocilizumab and Interferon $\alpha-2 \beta$ as an inpatient. The treatment success of this approach is $99.83 \%$ with a significant reduction in intubation and earlier discharge date.

\section{Limitations}

This research can only address the outcomes of people seen by a medical doctor. It cannot address patients treated by physicians in the outpatient setting without being seen by the physician and undergoing PCR screening with a positive result, consequently it cannot determine how many people were symptomatic or asymptomatic at drive through PCR testing sites and their outcomes. This study also cannot speak to smaller facilities that lacked the personnel and equipment to do the testing required for this study. The decision of who was selected at each study site was determined on site along with the randomization of treatments. Individuals who were intubated prior to receiving treatment were excluded from Treatment Arm 5 (Primaquine) although this only involved one patient. Finally, once admitted and the outpatient treatment for SARS-CoV-2 was discontinued, there may have been some residual impact from the aminoquinolines due to the long half-life of these drugs; however, when compared with those who entered the study who had not received aminoquinolines there was no difference in outcomes. 


\section{Conclusion}

This study established a rigorous assertive approach to treating and modifying SARS-CoV-2 treatments every three days. Rather than allowing patients to be treated with any given regimen for an extended period of time - given the absence of successful clinical trials and treatment - this study focused on rapidly adjusting treatment based upon measured changes in disease; specifically FMTVDM, Ferritin and IL-6 levels, in addition to conventional treatment monitoring. Using FMTVDM provided earlier measurement of treatment response allowing physicians the opportunity to act sooner to change treatments based upon tissue response to treatment. By taking this approach, treatments were added in 3-day intervals significantly reducing the time to treatment response. The lessons from Phase I lead to multi-drug regimens in Phase II following the same assertive approach. We believe the benefit of bronchodilator therapy and immune support beginning on day 1 cannot be underestimated both from an immune function and QTc cardiac perspective. The answer to the question, Is there a treatment for SARS-CoV-2 is yes however it depends upon where the patient is in the course of the disease. Accordingly patient treatment should focus on the stage of infection and immune response as shown in Figure 9. In the outpatient setting more than a quarter of the patients required no treatment as they were either asymptomatic or deemed to have very low risk and recovered without treatment. More than $40 \%$ of the outpatients were treated with an aminoquinoline and appear to have successfully been treated $69-100 \%$ of the time if they are started on treatment within the first couple days of symptoms. However, once patients progressed to the stage where hospitalization was required, aminoquinolines appear to have little or no effect. Despite reports of problems with ventricular dysrhythmias - perhaps owing to the prophylactic administration of magnesium and cardiology vigilance - there were no reports of Torsades de pointes or ventricular dysrhythmias.

\begin{tabular}{|c|c|c|c|c|c|}
\hline Pre-hospitalization & $\begin{array}{c}\text { Hospitalization } \\
\text { and Evaluation } \\
\text { of SARS-CoV-2 } \\
\text { severity } \\
\text { on Day } 1 .\end{array}$ & $\begin{array}{l}\text { Rx Acute Innate T-cell } \\
\text { Cytoxic Immune } \\
\text { Response } \\
\text { Beginning on Day } 1 .\end{array}$ & $\begin{array}{c}\text { Oxygenation } \\
\text { Begin on Day } 1 .\end{array}$ & $\begin{array}{l}\text { Evaluate Treatment } \\
\text { Response with } \\
\text { FMTVDM on Day } 3 \\
\text { after 72-hours of Rx. }\end{array}$ & $\begin{array}{c}\text { Delayed Adaptive } \\
\text { Humoral Immune \& ITR } \\
\text { Treatment. Day } 3 \\
\text { immediately after } \\
\text { FMTVDM. }\end{array}$ \\
\hline $\begin{array}{l}\text { Symptomatic or } \\
\text { High-risk groups. } \\
\text { Begin } \\
\text { HCQ, AZT or } \\
\text { alternative } \\
\text { (Primaquine \& } \\
\text { Clindamycin) to } \\
\text { inhibit viral } \\
\text { attachment and } \\
\text { replication. } \\
\text { Begin Immune } \\
\text { supportive Rx } \\
\text { including Zn. } \\
\text { Consider } \\
\text { combination } \\
\text { administration of } \\
\text { interferon } \alpha-2 \beta \\
\text { treatment with } \\
\text { other agents - } \\
\text { eg. Atrovent } \\
\text { inhalers/ } \\
\text { nebulizer; } \\
\text { aminoquinoline; } \\
\text { clindamycin. }\end{array}$ & $\begin{array}{l}\text { FMTVDM } \\
\text { measurement of } \\
\text { SARS-CoV-2. } \\
\text { Begin pre- } \\
\text { hospitalization Rxs } \\
\text { if not already } \\
\text { started. } \\
\text { ECG and Rx any } \\
\text { prolongation of } \\
\text { QTC with Esmolol, } \\
\mathrm{K}, \mathrm{Ca} \text { \& } \mathrm{Mg} \text {. } \\
\text { Measure } \\
\text { inflammatory \& } \\
\text { thrombotic } \\
\text { markers and treat } \\
\text { accordingly to } \\
\text { address and } \\
\text { prevent clotting } \\
\text { and further } \\
\text { uncontrolled } \\
\text { inflammation. } \\
\text { Do NOT merely } \\
\text { leave patient in } \\
\text { bed (chair, } \\
\text { ambulate, etc.). }\end{array}$ & $\begin{array}{l}\text { Initiate Additional } \\
\text { Treatment } \\
\text { Bronchodilator Rx with } \\
\beta-2 \text { agonist. } \\
\text { Consider adding } \\
\text { Primaquine } 200 \mathrm{mg} \text { one } \\
\text { time dose if not already } \\
\text { given. } \\
\text { Immediately add one of } \\
\text { the three following } \\
\text { treatment regimens to } \\
\text { address } \\
\text { InflammoThrombotic } \\
\text { Response (ITR). } \\
\text { (1) Tocilizumab \& } \\
\text { Interferon } \alpha-2 \beta \text {; } \\
\text { Primaquine, } \\
\text { (2) Clindamycin, } \\
\text { Tocilizumab \& } \\
\text { Interferon } \alpha-2 \beta, \text { or } \\
\text { (3) Methylprednisolone. }\end{array}$ & $\begin{array}{l}\text { Use incentive } \\
\text { spirometry for } \\
\text { Rx and measure } \\
\text { of respiratory } \\
\text { strength. } \\
\text { With any } \\
\text { compromise in } \\
\text { ventilatory } \\
\text { status begin } \\
\text { PRONE } \\
\text { positioning of } \\
\text { patient. } \\
\text { Consider } \\
\text { supplemental } \\
\text { oxygen and } \\
\text { BiPAP. } \\
\text { Prepare for V-V or } \\
\text { V-A ECMO } \\
\text { support. } \\
\text { If other measures } \\
\text { fail consider } \\
\text { ventilatory } \\
\text { support with VT } \\
\text { not to exceed } 5 \\
\text { cc/kg IDBW. } \\
\text { Extubate ASAP! }\end{array}$ & $\begin{array}{l}\text { FMTVDM } \\
\text { measurement to } \\
\text { determine Rx effect. } \\
\text { (1) Improved. Cont } \\
\text { Rx. } \\
\text { (2) Stable. Add next } \\
\text { level of Rx. } \\
\text { (3) Deterioration. } \\
\text { Change Rx. }\end{array}$ & $\begin{array}{l}\text { Adjust Rx given } \\
\text { FMTVDM results. } \\
\text { If further Rx is to be } \\
\text { added, select from } \\
\text { (1) Tocilizumab \& } \\
\text { Interferon } \alpha-2 \beta ; \text {; }(2) \\
\text { Primaquine, } \\
\text { Clindamycin, } \\
\text { Tocilizumab \& } \\
\text { Interferon } \alpha-2 \beta \text {, or (3) } \\
\text { Methylprednisolone. } \\
\text { Continue to } \\
\text { aggressively address } \\
\text { inflammatory and } \\
\text { clotting disorders } \\
\text { including efforts to } \\
\text { get patient out of bed } \\
\text { (chair, ambulate, etc.) } \\
\text { to avoid further } \\
\text { thromobotic and } \\
\text { inflammatory } \\
\text { problems. } \\
\text { Consider passive } \\
\text { immunity with } \\
\text { plasma with attention } \\
\text { directed to potential } \\
\text { associated clotting } \\
\text { potential. }\end{array}$ \\
\hline
\end{tabular}

Figure 9: Proposed SARS-CoV-2 Treatment Protocol.

Treatment of each patient with SARS-CoV-2 should focus on the stage of infection and InflammoThrombotic response (ITR) to the virus with measurement of the extent and severity of the disease and response to treatment.

Once patients required hospitalization, they responded favorably (99.83\%) to treatments focusing on reducing the InflammoThrombotic Response (ITR) resulting from the body's immune response to SARS-CoV-2. The combination of Remdesivir and Tocilizumab produced a limited treatment effectiveness compared to the expected impact of either drug alone suggesting a possible drug-drug interaction. Successful treatment interventions focused on (1) avoiding intubation or extubating the patient within a matter of days - less than one week - to minimize the ARDS associated ventilator complications associated with 
the immunologic ITR to SARS-CoV-2, in addition to (2) using a combination of treatments within the first few days of admission including Interferon $\alpha-2 \beta$, Tocilizumab, and Methylprednisolone. These combinations were most effective if the patient had already received an aminoquinoline as an outpatient, or Primaquine as an inpatient. When provided the administration of convalescent plasma proved effective; however, given the limited supply of convalescent plasma, the potential consequences of a blood product transfusion including increased potential for thrombosis as a plasma product, and the availability of effective ITR treatments, convalescent plasma should be reserved for cases not responding to Interferon $\alpha-2 \beta$, Tocilizumab, Methylprednisolone, or the combination of Tocilizumab with Interferon $\alpha-2 \beta$. These ITR drugs proved most promising when initiated upon admission and when used in combination, reducing hospitalization time from 30-45 days to as little as $18-25$ days with $0.17 \%$ mortality.

\section{Acknowledgment}

FMTVDM is patented \#9566037 to and owned by first author and was made available and provided without cost for the study. There are no other funding sources to report. Figures 1, 5 \& 6 are reproduced with permission. We would also like to acknowledge the following individuals who were responsible for their individual patient centers - C.C.F. (Germany; Sites 10,11,16,17 \& Belgium: Sites 9,13,14), J.0 (South Africa; Site 8), T.C.K. (India; Sites 2,3,7,15,18), R.K.V. (Brazil; Sites 12,19,20,23), S.A. (Cuba; Sites 1,4,22), and S.N.N (Philippines: Sites 5,6,21). The raw redacted data is available for clinicians and research scientists involved in SARS-CoV-2 patients and research, following expressed written request for and approval of written request for the data.

\section{References}

1. Wichmann D, Sperhake JP, Lütgehetmann M, Steurer S, Edler C, et al. (2020) Autopsy Findings and Venous Thromboembolism in Patients With COVID-19. A Prospective Cohort Study. Annals of Internal Medicine 6: M20-2003.

2. Fleming RM (1999) The Pathogenesis of Vascular Disease. Textbook of Angiology. John C Chang Editor Springer-Verlag New York, NY pp. 787798.

3. (2000) The Acute Respiratory Distress Syndrome Network. Ventilation With Lower Tidal Volumes As Compared With Traditional Tidal Volumes For Acute Lung Injury And The Acute Respiratory Distress Syndrome. N Engl J Med 342(18): 1301-1308.

4. (2004) The National Heart, Lung, and Blood Institute ARDA Clinical Trials Network. Higher versus Lower Positive End-Expiratory Pressures in Patients with the Acute Respiratory Distress Syndrome. N Engl J Med 351(4): 327-336.

5. Thiruvenkatarajan V, Lee JY, Sembu M, Watts R, Van Wijk RM (2019) Effects of esmolol on QTc interval changes during tracheal intubation: a systematic review. BMJ Open 9: e028111.

6. Al-Horani RA, Kar Srab, Aliter KF (2020) Potential Anti-COVID-19 Therapeutics that Block the Early Stage of the Viral Life Cycle: Structures, Mechanisms, and Clinical Trials. Int J Mol Sci 21(15): 5224.

7. Pradhan S, Madke B, Kabra P, Singh AL (2016) Anti-inflammatory and Immunomodulatory Effects of Antibiotics and Their Use in Dermatology. In J Derm 61(5): 469-481.
8. Camarda G, Jirawatcharadech J, Priestley RS, Saif A, March S, et al. (2019) Antimalarial activity of primaquine operates via a two-step biochemical relay. Nature Communications 10(1): 3226.

9. Burdick JR, Durand DP (1974) Primaquine Diphosphate: Inhibition of Newcastle Disease Virus Replication. Antimicrob Ag Chemother 6(4): 460-464.

10. Fantini J, Di Scala C, Chahinian H, Yahi N (2020) Structural and molecular modeling studies reveal a new mechanism of action of chloroquine and hydroxychloroquine against SARS-CoVid-2 infection. International Journal of Antimicrobial Agents 55(5): 105960.

11. Xue J, Moyer A, Peng B, Wu J, Hannafon BN, et al. (2014) Chloroquine Is a Zinc Ionophore. PLoS One 9(10): e109180.

12. Retallack H, Lullo ED, Arias C, Knopp KA, Laurie MT, et al. (2016) Zika virus cell tropism in the developing human brain and inhibition by azithromycin. PNAS 113(50): 14408-14413.

13. Elfiky AA (2020) Ribavirin, Remdesivir, Sofosbuvir, Galidesivir, and Tenofovir against SARS-CoV-2 RNA dependent RNA polymerase (RdRp): A molecular docking study. Life Sciences 253: 117592.

14. Nishimoto N, Terao K, Mima T, Nakahara H, Takagi N, et al. (2008) Mechanisms and pathologic significances in increase in serum interleukin-6 (IL-6) and soluble IL-6 receptors after administration of an anti-IL-6 receptor antibody, tocilizumab, in patients with rheumatoid arthritis and Castleman disease. Blood 112(10): 3959-3964.

15. Michot J-M, Albiges L, Chaput N, Saada V, Pommeret F, et al. (2020) Tocilizumab, an anti-IL6 receptor antibody, to treat Covid-19 related respiratory failure: a case report. Annals of Oncology 31(7): 961-964.

16. Magro G (2020) SARS-CoV-2 and COVID-19: Is interleukin-6 (IL-6) the 'culprit lesion' of ARDS onset? What is there besides Tocilizumab? SGP130Fc. Cytokine 2(2): 100029.

17. Zhang C, Wu Z, Li J-W, Zhao H, Wang G-Q (2020) The cytokine release syndrome (CRS) of severe COVID- 19 and Interleukin-6 receptor (IL-6R) antagonist Tocilizumab may be the key to reduce the mortality. Journal of Antimicrobial Agents preprint 55(5): 105954.

18. Giefing-Kröll C, Berger P, Lepperdinger G, Grubeck-Loebenstein B (2015) How sex and age affect immune responses, susceptibility to infections, and response to vaccination. Aging Cell 14: 309- 321.

19. Regan JC, Brandão AS, Leitão AB, Dias AR M, Sucena E, et al. (2013) Steroid Hormone Signaling Is Essential to Regulate Innate Immune Cells and Fight Bacterial Infections in Drosophila. PLOS Pathogens 9(10): e1003720.

20. Elenkov IJ (2004) Glucocorticoids and the Th1/Th2 Balance. Ann N Y Acad Sci 1024: 138-146.

21. Dong N, Tong Q (2020) A retrospective cohort study of methylprednisolone therapy in severe patients with COVID-19 pneumonia. Signal Transduction and Targeted Therapy 5(1): 57.

22. Hung IF-N, Lung K-C, Tso E Y-K, Liu R, Chung T W-H, et al. (2020) Triple combination of interferon beta-1b, lopinavir-ritonavir, and ribavirin in the treatment of patients admitted to hospital with COVID-19: a openlabel, randomized, phase 2 trial. Lancet 395(10238).

23. Stewart CE, Randall RE, Adamson CS (2014) Inhibitors of the Interferon Response Enhance Virus Replication In Vitro. PLoS One 9(11): e112014.

24. Mair-Jenkins J, Saavedra-Campos M, Baillie JK, Cleary P, Khaw F-M, et al. (2015) The Effectiveness of Convalescent Plasma and Hyperimmune Immunoglobulin for the Treatment of Severe Acute Respiratory Infections of Viral Etiology: A Systematic Review and Exploratory Metaanalysis. JID 211(1): 80-90.

25. Shen C, Wang Z, Zhao F, Yang Y, Li J, et al. (2020) Treatment of 5 Critically Ill Patients With COVID-19 With Convalescent Plasma. JAMA 323(16): 1582-1589.

26. (2017) The Fleming Method for Tissue and Vascular Differentiation and Metabolism (FMTVDM) using same state single or sequential quantification comparisons. Patent Number 9566037. 
27. Fleming RM, Fleming MR, Chaudhuri TK, Dooley WC (2019) Independent Study Validating FMTVDM Measurements of Breast Cancer and Transitional Tissue Changes with Confirmation of Gompertz Function \& Laird Model. Inter J Res Studies Med \& Health Sci 4(10): 21-26.

28. Rosário C, Zandman-Goddard G, Meyron-Holtz EG, D’cruz DP, Shoenfeld $Y$ (2013) The Hyperferritinemic Syndrome: macrophage activation syndrome, Still's disease, septic shock and catastrophic antiphospholipid syndrome. BMC Med 11: 185.

29. Aziz M, Fatima R, Assaly R (2020) Elevated interleukin-6 and severe COVID-19: A meta-analysis. J Med Viol 92(11): 2283-2285.

\section{ISSN: 2574-1241}

DOI: 10.26717/BJSTR.2021.33.005443

Richard M Fleming. Biomed J Sci \& Tech Res

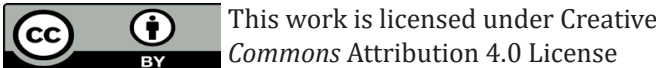

Submission Link: https://biomedres.us/submit-manuscript.php
30. NIH Launhes AI, Medical Imaging Center to Combat COVID-19.

31. Dhand R, Tobin MJ (1997) Inhaled Bronchodilator Therapy in Mechanically Ventilated Patients. Am J Respir Crit Care Med 156(1): 3-10.

32. (1967) Statistical Methods (6 ${ }^{\text {th }}$ Edn.). by Snedecor and Cochran. (C) The Iowa State University Press, Ames, Iowa, USA.

33. https://www.graphpad.com/guides/prism/8/user-guide/bar_graphs. htm

$\begin{array}{ll}\text { BIOMEDICAL } & \text { Assets of Publishing with us } \\ \text { RESEARCHES } & \text { - Global archiving of articles } \\ \text { - Immediate, unrestricted online access } & \text { - Rigorous Peer Review Process } \\ & \text { - Authors Retain Copyrights }\end{array}$

